


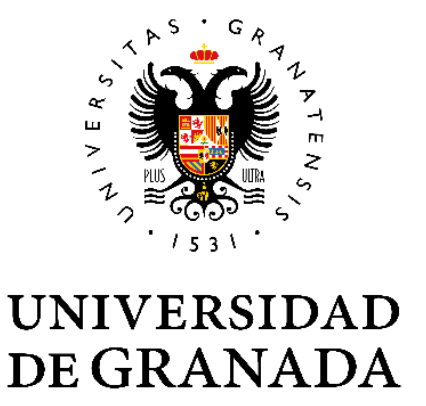

\section{La cuantificación como herramienta de optimización en el análisis de ADN mitocondrial en restos óseos antiguos.}

Trabajo Fin de Máster.

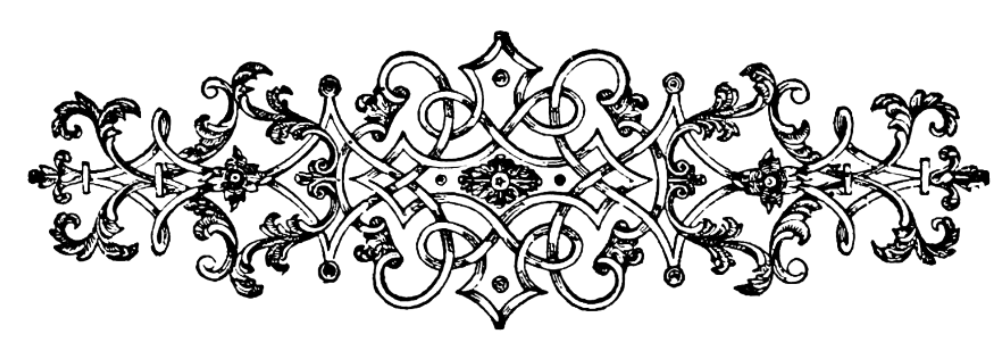

MSc. Antropología Física y Forense.

Autor: Christian Haarkötter Cardoso.

Tutores: Dr. Juan Carlos Álvarez Merino.

Dra. María Saíz Guinaldo.

Junio de 2019. 
"A partir de una gota de agua - decía el autor - un lógico puede deducir la posible existencia de un océano Atlántico o un Niágara, sin haberlos visto ni haber tenido nunca noticias de ellos. Por lo tanto, toda la vida es una larga cadena, cuya naturaleza se manifiesta cada vez que nos encontramos con uno de sus eslabones."

(Conan Doyle, 1887). 
A Carlos y María, mis guías en el mundo del ADN.

A Xiomara, mi compañera de pipetas.

A Rosa.

A Delfina Almeida Rodríguez. 


\section{Contenido}

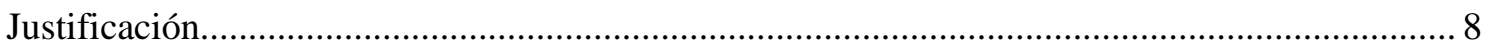

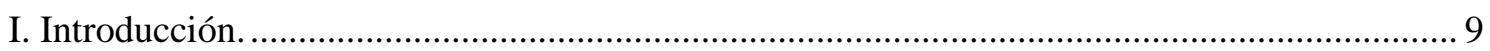

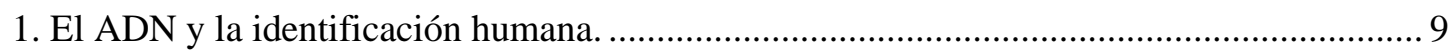

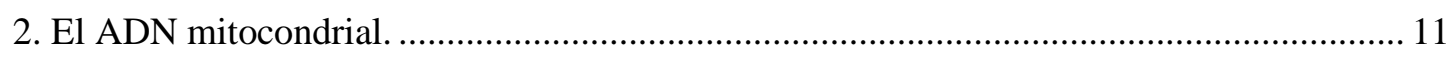

2.1. Características del ADN mitocondrial. .................................................................... 12

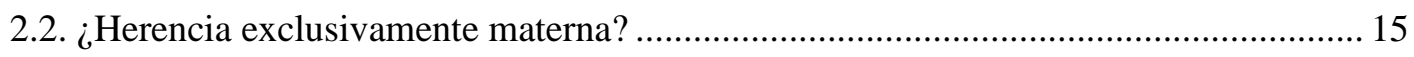

2.3. La Secuencia de Referencia de Cambridge (CRS).................................................. 15

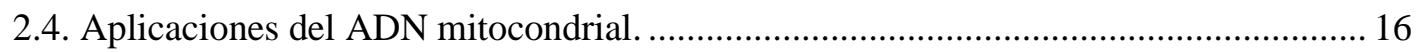

2.5. Problemática del análisis de ADN mitocondrial...................................................... 17

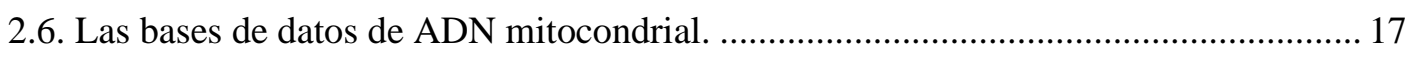

3. El análisis de ADN mitocondrial en restos óseos antiguos................................................ 19

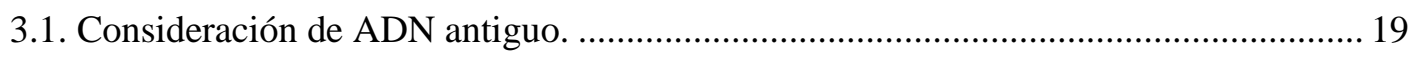

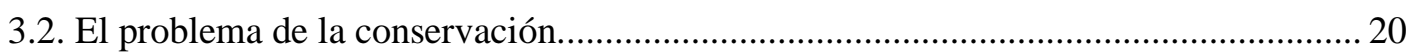

3.3. La importancia de la muestra de restos óseos. ............................................................. 22

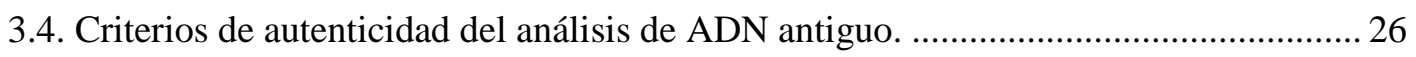

4. Procedimiento de análisis de ADN mitocondrial en restos óseos........................................ 27

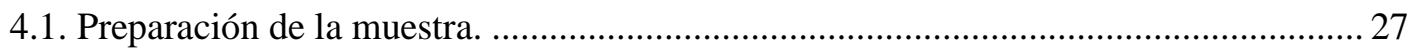

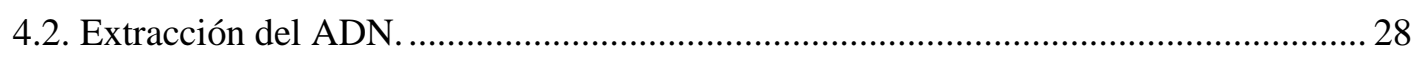

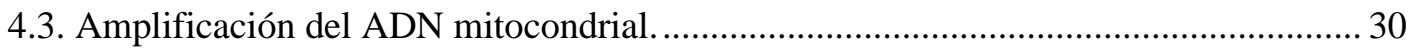

4.4. Purificación del producto de amplificación..................................................................... 34

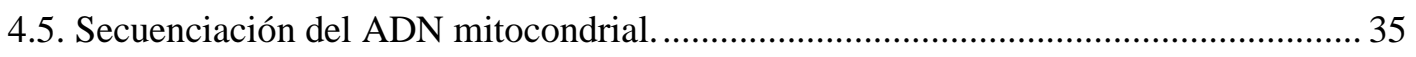

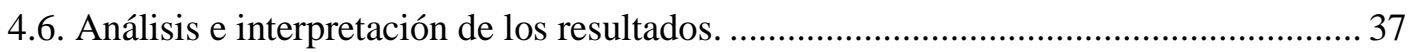

5. La secuenciación de nueva generación (NGS) ................................................................... 41

6. Los grupos de trabajo sobre análisis de ADN mitocondrial................................................. 44

7. La cuantificación de ADN como herramienta de optimización del análisis de ADN......... 45

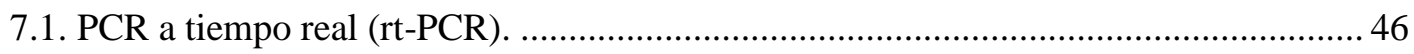

7.2. Cuantificación de ADN mitocondrial por rt-PCR..................................................... 50

8. Objetivos y metodología del Trabajo Fin de Máster............................................................ 52 


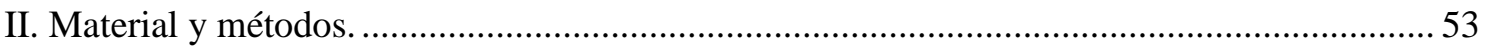

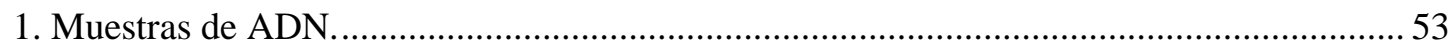

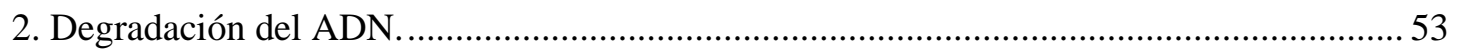

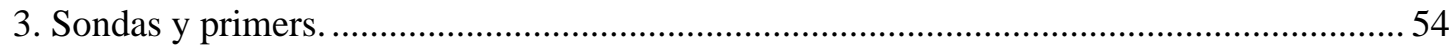

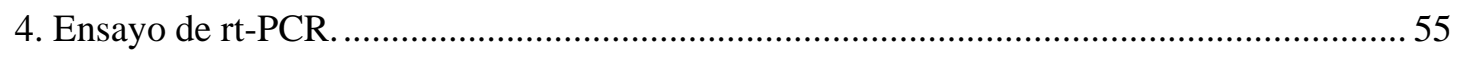

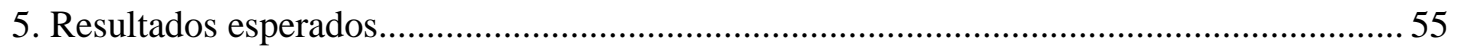

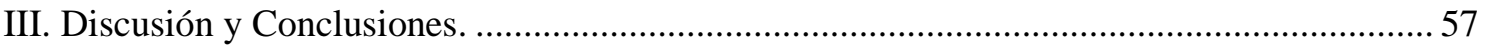

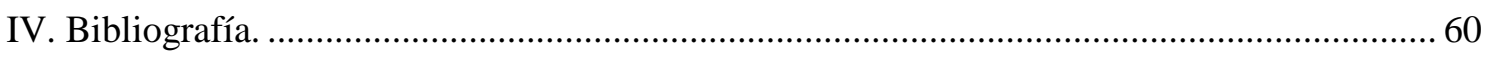

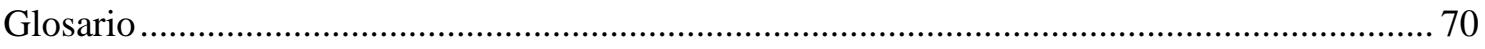


Resumen: El análisis de ADN mitocondrial en restos óseos antiguos tiene multitud de aplicaciones como son la identificación humana, los estudios poblacionales, o la identificación de especies no humanas, sumándose su interés al del análisis de restos óseos antiguos: desaparición de personas, víctimas de atentados terroristas, víctimas de grandes catástrofes, restos de fosas comunes en conflictos bélicos, litigios de filiación o las adopciones irregulares. No obstante, el análisis no está exento de problemas técnicos que impiden la obtención de un resultado, como son fundamentalmente la degradación del $\mathrm{ADN}$, proceso natural tras la muerte que se ve acentuado en muchas ocasiones por la acción de microorganismos, sustancias, o factores como el pH o la temperatura; y la inhibición de la actividad de la reacción en cadena de la polimerasa (PCR) motivada por sustancias que causan dicha inhibición. El presente trabajo pretende diseñar un experimento para mostrar la utilidad de la realización de una cuantificación del ADN mitocondrial inmediata a la extracción para, mediante PCR a tiempo real, determinar la cantidad de ADN mitocondrial presente y el estado de degradación del mismo, y así establecer la vía analítica más favorable para la obtención de un resultado. Para ello, se van a degradar muestras de ADN genómico con nucleasas en diluciones seriadas y a distintos intervalos de tiempo para, posteriormente, cuantificar dos fragmentos, uno corto y uno largo, de la región del 16S rRNA, obteniendo al mismo tiempo información sobre la cantidad y la calidad.

Palabras clave: ADN antiguo. ADN mitocondrial. Cuantificación rt-PCR. Genética Forense. Restos óseos.

Summary: Mitochondrial DNA analysis in skeletal remains has multiple applications like human identification, population studies, or non-human species identification, adding it interest to ancient skeletal remains analysis: missing people, terrorist attacks victims, disaster victim identification, armed conflict potter's field, filiation legal cases, or irregular adoptions. However, analysis is not exempt of technical problems which impede obtaining any result, we are talking about DNA degradation, a natural process after organism death which is increased by the action of microorganisms, some substances or the action of factors like $\mathrm{pH}$ or temperature; and PCR inhibition, motivated by some substances. The present work aims to show the utility of the realization of a mitochondrial DNA quantification immediately after extraction in order to, by real time PCR, determining the present mitochondrial DNA quantity and how degraded it is, so we can choose the most favorable analytical step in order to get any result. To achieve that we are going to design an experiment in which we are going to artificially degrade genomic DNA with DNases in serial dilutions in different time lapses and then we will quantify it in two fragments, one longer one shorter, from 16S rRNA region, obtaining information about mitochondrial DNA quantity and quality.

Key words: Ancient DNA. DNA rt-PCR Quantification. Forensic Genetics. Mitochondrial DNA. Skeletal remains. 
Hoy en día, el análisis de ADN es una de las piedras angulares de las Ciencias Forenses, teniendo una espectacular evolución desde los primeros perfiles de ADN realizados en los años 80. Este desarrollo no ha estado exento de dificultades, y actualmente una de las principales problemáticas que se presentan es el análisis de ADN en restos óseos antiguos, problema que se presenta en numerosos casos, como los sucesos de víctimas múltiples, o el contexto de la Memoria Democrática en Andalucía en el marco de la Ley 2/2017, de 28 de marzo, de Memoria Histórica y Democrática de Andalucía.

$\mathrm{El}$ análisis forense de $\mathrm{ADN}$ en restos óseos antiguos es una de las cuestiones que está dando problemas actualmente a la Criminalística en tanto que no dispone de una metodología que contemple la diversa casuística que puede presentarse para la obtención de resultado adecuado. El estudio genético de los restos óseos cobra especial importancia en personas desaparecidas, atentados terroristas, grandes catástrofes, fosas comunes de conflictos bélicos y litigios relacionados con la filiación o adopciones irregulares, casos que se presentan en nuestro país con relativa frecuencia y de los que se demanda una solución pronta y eficaz. Como hemos adelantado, el objetivo de establecer la identificación de unos restos óseos mediante el análisis de ADN comparándolos con una muestra indubitada, ya sea de la propia víctima o de un/unos familiar/es, está rodeado de dificultades, como son la conservación del ADN, la inhibición de la PCR, la contaminación de las muestras, o la propia selección de las muestras.

Son dos, por tanto, las principales fuentes de problemas a la hora de analizar ADN en restos óseos antiguos: la muestra en sí misma, sometida a distintos procesos de degradación que ya hemos esbozado, y por otra parte la identificación, pues la misma se hace por comparación con el material genético de supuestos familiares del individuo al que pertenecen los restos, parentesco que en ocasiones y dependiendo de los casos suele ser lejano. Aunque en el análisis forense son los Short Tandem Repeats o STRs (secuencias cortas cuyo número de repeticiones varía entre individuos) lo que más atención reciben, cabe señalar el potencial del análisis de ADN mitocondrial, caracterizado por tener un mayor número de copias por célula, lo que permitiría trabajar con muestras mínimas o degradadas, como es el caso de los restos óseos antiguos. No obstante, la gran variedad de técnicas analíticas disponibles hace necesaria una optimización del proceso. El presente Trabajo Fin de Máster pretende resaltar la cuantificación del extracto de ADN mediante PCR a tiempo real como herramienta de optimización del análisis de ADN mitocondrial. 


\section{Introducción.}

\section{EI ADN y la identificación humana.}

Las aportaciones de la Biología a la Criminalística han sido innumerables. Se suele citar como inicio de las mismas el libro de Sung Tz'u del siglo XIII, The washing away of wrongs, en el que el forense chino relata un asesinato del cual se dedujo por las heridas que había sido cometido por una hoz, siendo dos los campesinos sospechosos. De modo que se les pidió que trajeran sus instrumentos y los dejaron al sol; las moscas acudieron al lugar y se posaron sobre una hoz, delatando al mismo tiempo al arma homicida y al presunto culpable (Sung Tz'u, 1981). Siglos después, el descubrimiento de los tipos sanguíneos de Landsteiner en 1900 y el desarrollo de la prueba de inmunodifusión doble de Ouchterlony en 1948 permitía determinar la especie a la que pertenecía una mancha de sangre y lograr una cierta individualización de la misma (Thorwald, 1966). Pero el problema seguía siendo el mismo: ¿a quién pertenece?

Gracias a los descubrimientos de Rosalind Franklin obtenidos con difracción de rayos X, Watson y Crick pudieron elaborar en 1953 el modelo de la doble hélice de ADN, relativo a su estructura y composición. El ácido desoxirribonucleico (ADN) es una molécula de doble cadena formada por grupos fosfato, una pentosa (la desoxirribosa, así denominada por haberse reducido su segundo carbono), y una base nitrogenada, que puede ser adenina, guanina (bases púricas), timina, o citosina (bases pirimidínicas). Esta doble cadena, de carga negativa, es antiparalela, y complementaria, de modo que la información contenida en una se complementa con la presente en la otra cadena. La magia está en que es la secuencia de las distintas bases nitrogenadas contenida en esa cadena la que se va a traducir en la síntesis de una determinada proteína, dando como resultados las distintas características de los seres vivos. De esta manera podemos clasificar el ADN en codificante, el que contiene la información para la síntesis de una determinada proteína, y el ADN no codificante, cuya información no tiene, aparentemente, utilidad (Lorente, 2004).

En 1985 apareció en la revista Nature un pequeño artículo en el que tres científicos habían conseguido aislar ADN de gran masa molecular relativa de manchas de sangre de más de 4 años de antigüedad y manchas de semen para producir "huellas dactilares" de ADN para la identificación individual; lo que es más, los núcleos de los espermatozoides pueden ser separados de las células epiteliales vaginales, lo que permite identificar en una agresión sexual a agresor y víctima, todo ello con un índice de probabilidad muchísimo mayor que la proporcionada por las pruebas inmunológicas de Ouchterlony (Gill, Jeffreys, \& Werret, 1985). En 1986, en el pueblo de Narborough, un hombre confesó haber agredido sexualmente y posteriormente matado a dos chicas, de modo que el descubrimiento de Jeffreys venía como anillo al dedo para comparar el 
material genético del semen hallado en los cuerpos de las víctimas con la sangre de este hombre, dando resultado negativo. Curiosamente, la primera vez que el ADN se usó como fines forenses fue para demostrar la inocencia de una persona. El siguiente paso fue hacer un espectacular barrido por el material genético de todo el pueblo y pueblos cercanos, hasta que la declaración de una mujer sirvió para localizar a un sospechoso, cuyo ADN coincidió perfectamente con el hallado en los cuerpos. Desde entonces, hasta la actualidad, el avance del análisis forense de ADN ha sido imparable, propiciado de una parte por los avances en las técnicas, y por otra del desarrollo de la Informática (Butler, 2005).

Centrándonos ya en el ADN no codificante, Jeffreys observó que hay determinadas regiones minisatélites, de entre 8 y 100 pares de bases, que diferían entre individuos, regiones a las que denominó VNTRs (Variable Number Tandem Repeats, repeticiones en tándem de número variable). Poco tiempo después se descubrieron unidades de repetición microsatélites, mucho más pequeñas, y a medida que se iban descubriendo nuevos loci de estas secuencias cortas de repetición (STR, Short Tandem Repeats) y el análisis de ADN participaba cada vez más en los procesos judiciales, los mismos iban adquiriendo notoriedad hasta que en 1994 Promega desarrolla el primer kit multiplex para STRs mediante PCR (Reacción en Cadena de la Polimerasa), disparando el uso forense de estas secuencias para identificación humana, pues esta técnica analítica permitía obtener miles de copias de un mismo fragmento de pequeño tamaño, haciéndolo detectable (Butler, 2010).

Años antes, en 1977, un bioquímico británico desarrolló un método con el que mediante el empleo de dideoxinucleótidos (sintetizando cadenas de 1,2 ...n nucleótidos unidos a un terminador que libera la ADN polimerasa de la cadena molde), se podía secuenciar el ADN (Sanger, Nicklen, \& Coulson, 1977), es decir, determinar los distintos nucleótidos que componen la cadena de material genético. Esta nueva técnica permitió el desarrollo del Proyecto Genoma Humano, cuya actividad frenética desembocó en el descubrimiento de variaciones de un solo nucleótido en un mismo individuo, Single Nucleotide Polymorphism o SNPs (Brookes, 1999), pero no fue hasta finales de los años 90 y principios de los 2000 cuando se empezó a plantear su utilidad en las ciencias forenses, mayormente a la hora de establecer relaciones de parentesco (Gill, 2001). El análisis forense de los SNPs presenta muchas ventajas con respecto al análisis de STRs: permite trabajar mejor con muestras mínimas o degradadas por necesitar observar las variaciones en un solo nucleótido, la tasa de mutación de los SNPs es mucho menor que la de los marcadores tipo STR, pero necesita de un mayor número de marcadores (en torno a 40-60) para igualar la confianza de los resultados de 13-15 marcadores STR, y plantean dificultades para interpretar las mezclas (Butler, Coble, \& Vallone, 2007). En la tabla 1 podemos ver una comparativa entre los marcadores STR y los SNP, y en la figura 1 un ejemplo gráfico de ambos tipos de marcadores. 
Tabla 1. Comparativa entre marcadores STR y SNP (Butler, 2010).

\begin{tabular}{|c|c|c|}
\hline Característica & STR & SNP \\
\hline $\begin{array}{l}\text { Frecuencia en el } \\
\text { genoma humano }\end{array}$ & Cada 15.000 bases & Cada 1000 bases \\
\hline Información & Alta & Baja \\
\hline Tasa de mutación & $1 / 1000$ & $1 / 100.000 .000$ \\
\hline Tipo de marcador & $\begin{array}{c}\text { Repeticiones de dos, tres o } \\
\text { cuatro nucleótidos, con multitud } \\
\text { de alelos }\end{array}$ & $\begin{array}{l}\text { Bialélicos con seis } \\
\text { posibilidades. }\end{array}$ \\
\hline Alelos por marcador & $5-20$ & Normalmente 2 \\
\hline Método de detección & Electroforesis en gel o capilar & Secuenciación; chip de ADN \\
\hline Capacidad multiplex & $>10$ & Alrededor de 50 \\
\hline Tamaño del amplicon & $75-400$ pares de bases & No menos de 100 \\
\hline $\begin{array}{c}\text { Capacidad para } \\
\text { determinar ancestría }\end{array}$ & Limitada & SNPs asociados a ancestría \\
\hline Información fenotípica & No & Sí \\
\hline $\begin{array}{l}\text { Ventajas en las ciencias } \\
\text { forenses }\end{array}$ & Mejor interpretación de mezclas & $\begin{array}{c}\text { Muestras mínimas o muy } \\
\text { degradadas }\end{array}$ \\
\hline
\end{tabular}

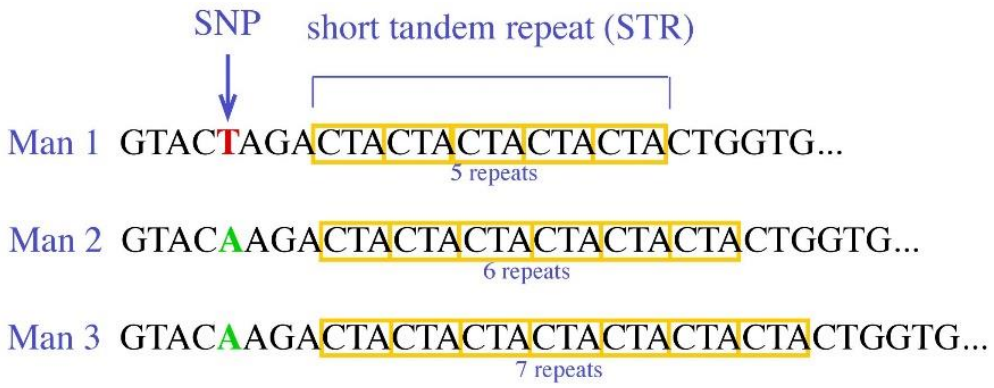

Figura 1. Representación gráfica de SNP y STR (Jobling, 2009).

\section{EI ADN mitocondrial.}

Aunque hemos estado hablado constantemente de ADN nuclear, el que se haya en el interior del núcleo celular, este no es el único que compone el genoma humano. La mitocondria es un orgánulo de doble membrana localizado en el citoplasma celular cuya función primordial es la generación de adenosín trifosfato (ATP), molécula de intercambio energético. Normalmente se heredan de un solo progenitor, en animales, habitualmente la madre (Pierce, 2006).

Pese a que el descubrimiento de la mitocondria fue bastante difuso, con el desarrollo del microscopio electrónico se observaron en las mitocondrias áreas de baja opacidad a los electrones que, mediante distintos métodos de fijación, a varios niveles de $\mathrm{pH}$ y a distintas concentraciones de salinidad, lo que indicaba que estas áreas eran componentes estructurales de las mitocondrias. Lo que era más: si se usaba un contraste con metales pesados en tejidos vivos se obtenían las mismas imágenes que las estructuras con ácidos nucleicos ya conocidas; así, empleando una fijación con tetraóxido de osmio, se podía observar una estructura fibrosa en las mitocondrias en forma de barra, en ocasiones con pequeños filamentos, que se extendía por toda la periferia de la 
mitocondria, una disposición muy similar al nucleoplasma de las bacterias (Nass \& Nass, 1963). Se trataba, efectivamente, del ADN mitocondrial, cuya relación con el orgánulo en el que se encuentra y la célula puede observarse en la figura 2. Cada célula tiene varias mitocondrias, teniendo cada una de ellas diversas copias del ADN mitocondrial; una mutación en el mismo citoplasma que desemboca en dos ADN mitocondrial diferentes se denomina heteroplasmia, y la propagación del ADN mitocondrial mutado por las distintas células del individuo segregación replicativa; denominándose homoplasmia a la herencia de la siguiente generación de uno u otro tipo de ADN mitocondrial exclusivamente (Pierce, 2006).

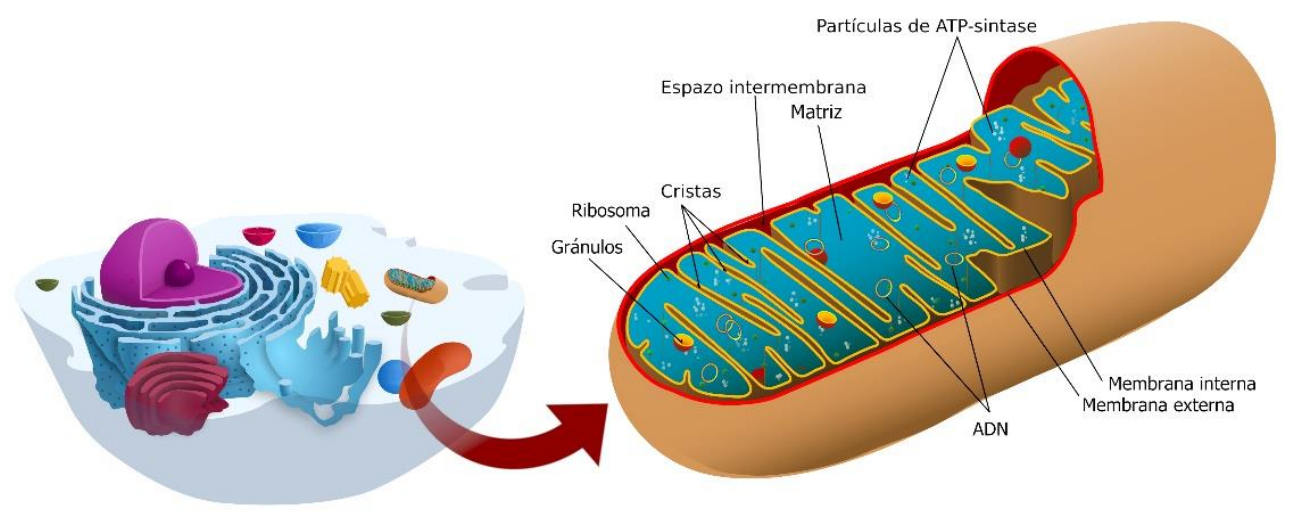

Figura 2. La mitocondria y sus estructuras. Fuente: Elaboración propia, a partir de Wikipedia

La similitud entre una mitocondria y las eubacterias no es casual, estando muy extendida en la comunidad científica la Teoría endosimbiótica, según la cual hace 1000 - 1500 millones de años una célula eucarionte anaerobia (esto es, que su material genético se encontraba delimitado por una envoltura nuclear y que no requiere oxígeno para la obtención de energía) asimiló por fagocitosis una eubacteria aerobia con las enzimas necesarias para la fosforilación oxidativa, la ruta metabólica de las mitocondrias para la obtención de energía en forma de ATP; esta relación simbiótica se iría seleccionando hasta que llegamos a las células eucariotas de hoy día. Las pruebas propuestas son diversas, estando las más prometedoras en el estudio del ADN mitocondrial que codifica proteínas, mucho más relacionados con las eubacterias que con las células eucariotas (Pierce, 2006).

\subsection{Características del ADN mitocondrial.}

El ADN mitocondrial tiene, aproximadamente, $\mathbf{1 6 5 6 9}$ pares de bases, número que puede variar debido a pequeñas mutaciones, ya sean inserciones o deleciones, y es circular y de doble cadena. La mayoría del genoma mitocondrial codifica las proteínas necesarias para la fosforilación oxidativa necesaria para la producción celular de energía, pero hay también una región de unos 1122 pares de bases denominada región control que contiene el origen de 
replicación, pero no tiene la información para la síntesis de ninguna proteína, por lo que también se la denomina región no codificante. Hay una distribución asimétrica de los nucleótidos en la doble cadena, de manera que se presenta una cadena pesada $(\mathrm{H}$, heavy), y una cadena ligera ( $\mathrm{L}$, light), debido a que la cadena pesada contiene una mayor proporción de nucleótidos de guanina, que son los que mayor masa molecular relativa tienen de los cuatro. La replicación del ADN mitocondrial empieza en la región no codificante en la cadena pesada en el denominado bucle de desplazamiento o D-loop. En la figura 3 puede apreciarse la estructura del ADN mitocondrial.

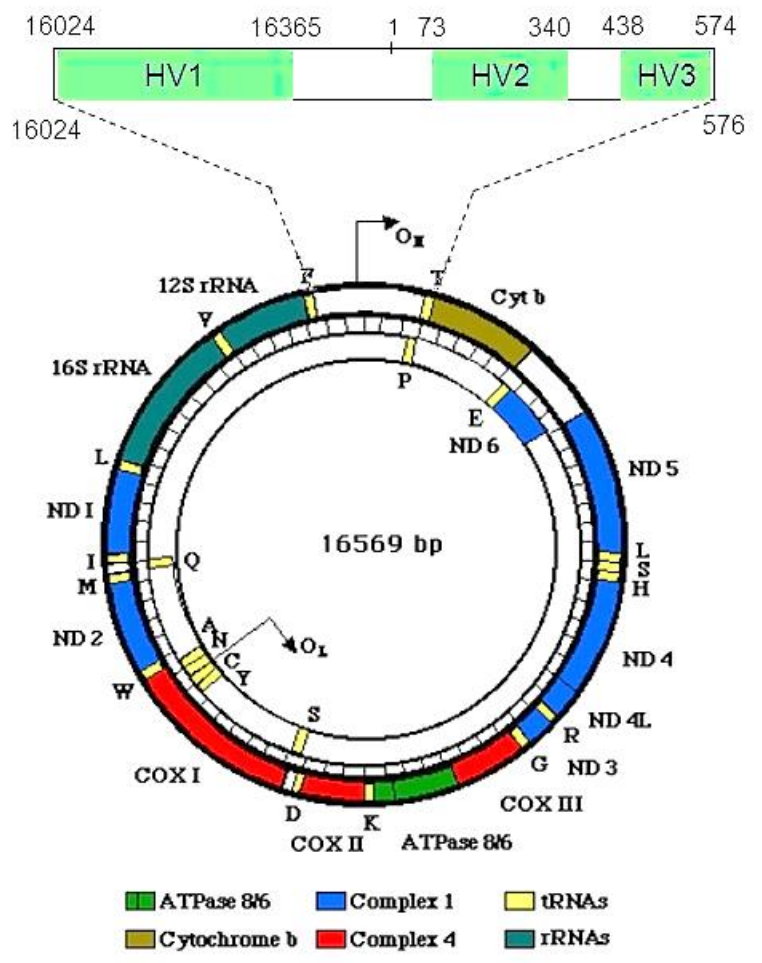

Figura 3. Estructura del ADN mitocondrial y su región control. Fuente: Elaboración propia, a partir de Wikipedia.

Como puede observarse, la región control del ADN mitocondrial presenta tres segmentos que se han identificado como altamente polimórficos entre individuos, denominadas regiones hipervariables, HV1 (16 024 - 16 365), HV2 (73 - 240) y HV3 (438 - 574), siendo las dos primeras, y ocasionalmente la tercera, las empleadas en análisis forense con fines identificativos. El ADN mitocondrial presenta una serie de características que lo hacen especialmente interesante para multitud de áreas de estudio (Álvarez et al., 2001):

1) Herencia materna. En la fecundación se produce la entrada de la cabeza del espermatozoide, estando las mitocondrias de este en el cuello, al tiempo que el óvulo presenta mecanismos para neutralizar las mitocondrias del espermatozoide que puedan entrar en el mismo. De este modo, el haplotipo de hermanos, hijos, madre, y en general los parientes por línea materna (véase el diagrama que se muestra en la figura 4) es idéntico. 
2) Alto número de copias. Pese a que el $\mathrm{ADN}$ mitocondrial es más pequeño, son de 10 a 100 las mitocondrias presentes a cada célula, teniendo cada una de ellas de 10 a 100 copias de ADN, lo que nos daría de 100 a 10000 copias de la molécula de ADN mitocondrial por célula.

3) Alta tasa de mutación. El ADN mitocondrial presenta una tasa de mutación 5-10 veces mayor que el ADN nuclear, debido a que está en una zona con un bombardeo constante de radicales libres, al tiempo que no está protegido por el empaquetamiento con histonas característico del ADN nuclear, a lo que se unen la baja fidelidad de la polimerasa del ADN mitocondrial y la carencia de mecanismos de reparación.

4) Heteroplasmia. Puede darse el caso de que coexistan dos secuencias distintas de ADN mitocondrial, ya sea en una misma mitocondria, en una misma célula o en un mismo individuo, determinando la segregación replicativa los niveles de heteroplasmia. Las mismas pueden ser:

a) De secuencia. En una posición determinada hay más de una base, como es la existencia de $\mathrm{C} / \mathrm{T}$.

b) De longitud. Hay una variación en el número de bases de un homopolímero, por ejemplo, el número de citosinas en el fragmento poliC de HV2.

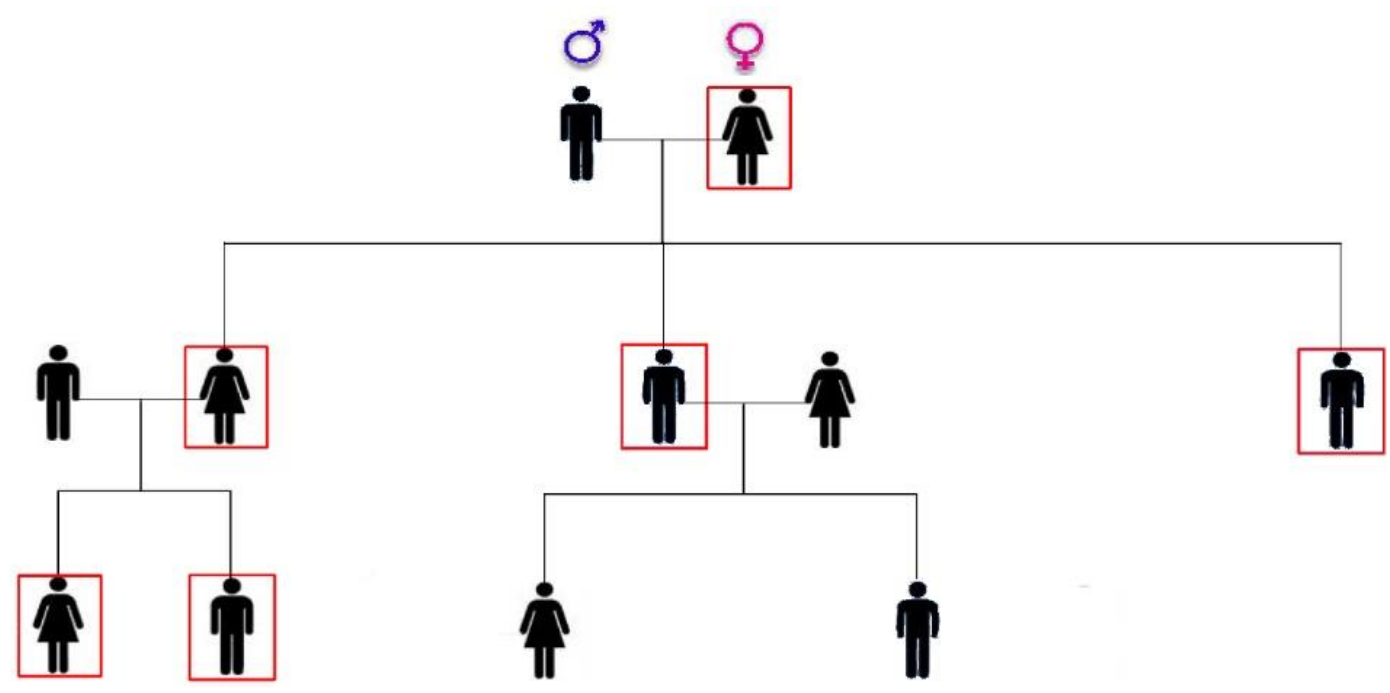

Figura 4. Esquema de la herencia materna del ADN mitocondrial. Fuente: Laboratorio de Identificación Genética (Universidad de Granada).

En la tabla 2 puede verse un resumen de estas características, así como su comparativa con el ADN nuclear. 
Tabla 2. Comparativa entre el ADN nuclear y el ADN mitocondrial (Butler, 2010)

\begin{tabular}{|c|c|c|}
\hline Característica & ADN nuclear & ADN mitocondrial \\
\hline Tamaño & $\sim 3,2$ millones de pares de bases & 16 569 pares de bases. \\
\hline Copias por célula & 2 & $100-10000$ \\
\hline Cantidad del genoma & $99,75 \%$ & $0,25 \%$ \\
\hline Estructura & Lineal & Circular \\
\hline Herencia & Biparental & Materna \\
\hline Ploidía & Diploide & Haploide \\
\hline Recombinación & Sí & No \\
\hline $\begin{array}{l}\text { Reparación de } \\
\text { replicación }\end{array}$ & Sí & No \\
\hline Individualidad & $\begin{array}{l}\text { Único excepto en gemelos } \\
\text { univitelinos. }\end{array}$ & No diferencia la línea materna. \\
\hline Tasa de mutación & Baja. & $\begin{array}{c}\text { De } 5 \text { a } 10 \text { veces la del ADN } \\
\text { nuclear. }\end{array}$ \\
\hline Secuencia de referencia & $\begin{array}{l}\text { Proyecto Genoma Humano } \\
\text { (2001). }\end{array}$ & $\begin{array}{l}\text { Secuencia de Cambridge } \\
\text { (1981). }\end{array}$ \\
\hline
\end{tabular}

\section{2. ¿Herencia exclusivamente materna?}

La herencia materna como característica del ADN mitocondrial está actualmente (y nuevamente) en discusión; la misma se inició en 2002 con un informe en el que se analizaba el ADN mitocondrial de un individuo con dificultades para hacer ejercicio, descubriéndose que el mismo presentaba heteroplasmias compuestas por ADN mitocondrial de la madre y de su padre. La cuestión ha vuelto a salir a la palestra científica con un reciente y controvertido estudio en el que se analizan 17 miembros de tres familias diferentes con altos niveles de heteroplasmias en su ADN mitocondrial, trece de los cuales fueron caracterizados mediante secuenciación de su genoma mitocondrial, deduciéndose la secuencia de los restantes individuos a partir del análisis de las heteroplasmias maternas presentes (Luoa et al., 2018).

Bien es cierto que el modelo falsacionista de la Ciencia de Popper sigue teniendo una gran fortaleza en el ámbito científico, entendiendo que la Ciencia avanza mediante la falsación de afirmaciones (Chalmers, 2010). No obstante, por el momento podemos considerar los casos de herencia paterna de ADN mitocondrial como casos excepcionales que, en el presente estado de la cuestión, no invalidan la regla general de herencia matera. Debemos esperar a estudios más exhaustivos y amplios para determinar esta cuestión, lo que no quita que cuando se tenga ocasión se hagan todos los estudios posibles para, llegado el caso, tener en cuenta esta posible eventualidad.

\subsection{La Secuencia de Referencia de Cambridge (CRS).}

Gracias a los avances de Sanger y su equipo en secuenciación de ADN, en 1981 se publicó la secuenciación completa del ADN mitocondrial, que posteriormente se vino a conocer como la Secuencia de Referencia de Cambridge (CRS por sus siglas en inglés, llamada así por la 
Universidad en la que tuvo lugar el proyecto), lo que permitió el estudio de todas las características que acabamos de ver, como su estructura en dos cadenas o las 16569 pares de bases que se suele decir que tiene (Anderson et al., 1981). La utilidad de la CRS fue instantánea para el estudio de haplogrupos o de enfermedades relacionadas con el metabolismo mitocondrial, pero en años posteriores se vio que la secuencia obtenida por varios investigadores no se correspondía con la proporcionada por Sanger, de modo que se volvió a analizar con 28 fragmentos solapantes (Andrews et al., 1999), obteniéndose la Secuencia de Referencia de Cambridge revisada (rCRS), que es la empleada actualmente, si bien la CRS y la rCRS son iguales a nivel de la región control. La misma se utiliza en identificación humana mediante su comparación con la secuencia analizada para el caso concreto, viéndose si los polimorfismos observados entre la muestra dubitada y la rCRS. son los mismos que los vistos en la muestra indubitada y dicha secuencia.

Dado que que la información de la CRS corresponde a una mujer de ascendencia europea, se han ido proponiendo otras secuencias de otras poblaciones, argumentándose que el empleo de una secuencia del haplogrupo $\mathrm{H}$, como es el caso, como secuencia de referencia, deriva en problemas como la confusión entre lo que se correspondería entre una variabilidad polimórfica y la verdadera ancestralidad, o tratar mutaciones sinónimas como si no lo fueran. Es por ello que se ha propuesto la Secuencia de Referencia Reconstruida del Sapiens (Reconstructed Sapiens Reference Sequence, RSRS), construida con la información de 8216 genomas mitocondriales, incluso del Homo neanderthalensis (Behar et al., 2012).

\subsection{Aplicaciones del ADN mitocondrial.}

A tenor de las distintas características que exhibe el ADN mitocondrial, las principales aplicaciones que tiene su investigación son (Álvarez et al., 2001):

A) Identificación humana. Cuando la muestra biológica de la que se dispone es muy pequeña o está degradada, como son los pelos sin bulbo o los restos óseos antiguos, el ADN mitocondrial se luce y obtiene información de donde otras técnicas han fallado para conseguir la identificación de una persona.

B) Investigación biológica de relaciones de familiaridad. Permite relacionar individuos emparentados por línea materna.

C) Estudios poblacionales. Los distintos haplotipos de la región control han servido a la Antropología molecular para establecer distintas líneas evolutivas.

D) Identificación de especies no humanas. El análisis de determinados segmentos, como el gen que codifica el citocromo B se emplean para identificar la especie. 


\subsection{Problemática del análisis de ADN mitocondrial.}

Como cualquier otra metodología de estudio, el análisis de ADN no está exento de problemas, y lo mismo sucede con el ADN mitocondrial (Butler, 2010):

1) Herencia únicamente materna. El análisis de $\mathrm{ADN}$ mitocondrial no es aplicable a individuos que no estén conectados por vía materna, y tampoco distingue a los individuos de la misma línea materna. Por ejemplo, el ADNmt de dos hermanos es indistinguible al de su madre.

2) Heteroplasmias. La presencia de más de un ADNmt en un mismo individuo complica el análisis.

3) Ausencia de recombinación. Siendo de herencia exclusiva y directamente materna (se hereda en bloque), el poder de discriminación va a estar limitado por el tamaño de la base de datos con la que se trabaje.

\subsection{Las bases de datos de ADN mitocondrial.}

La enorme variabilidad de polimorfismos presentes en el ADN mitocondrial, unido al creciente interés que tuvo en el campo médico en relación a la investigación de algunas enfermedades, motivó a que en 1996 investigadores de la Universidad de Emory crearan una base de datos a la que denominaron MITOMAP (Kogelnik, Lott, Brown, Navathe, \& Wallace, 1996), constituyéndose como una base de datos colaborativa en la que los diversos investigadores aportan sus propias referencias de polimorfismos que han hallado en sus investigaciones. Actualmente las frecuencias que reportan se basan en 47412 secuencias completas de ADN mitocondrial y 71091 secuencias de la región control.

La necesidad de disponer de una base de datos de ADN mitocondrial de uso forense, con sus correspondientes garantías de calidad, motivó a que en el XVIII Encuentro de la International Society for Forensic Genetics (ISFG) se creara una base de datos que fuera abierta para toda la comunidad forense y que permitiera disponer de datos con la calidad suficiente sobre ADNmt, para su uso forense, surgiendo así EMPOP (European DNA Profiling Group mtDNA Population Database), que se caracteriza por la exigencia de control de calidad a los laboratorios que remiten un resultado, al tiempo que la base de datos cuenta con un software que busca errores en los mitotipos que se introducen (Walther Parson \& Dür, 2007). Actualmente EMPOP cuenta con 42839 mitotipos de los cuales 41385 cubren HV1 y HV2, 33447 cubren la región control completa y 1366 el mitogenoma completo. A la hora de hablar de bases de datos genéticas de uso forense es imposible no acordarse de CODIS, que, si bien emplea STRs únicamente (en materia de investigación criminal), en personas desaparecidas (bases de datos genéticas civiles o no criminales) permite a los diferentes laboratorios subir a su vez información de ADN mitocondrial, 
de HV1 y HV2, aunque se prevé una nueva edición del programa con un mayor uso del genoma mitocondrial (Federal Bureau Investigation, s. f.)

Las bases de datos de ADN mitocondrial también tienen un gran interés para los estudios de Antropología Molecular. Hemos visto que los distintos haplotipos de ADN mitocondrial, teniendo en cuenta las características de su herencia, pueden agruparse y hacerse estudios poblacionales en haplogrupos que complementan y ayudan enormemente la labor histórica y arqueológica, destacando aquí PhyloTree, que contiene 5400 haplogrupos diferentes, con las mutaciones que los definen (van Oven, 2009). En la figura 5 se puede ver el árbol filogenético humano generado a partir de polimorfismos de ADNmt. Otra herramienta muy útil para la determinación de haplogrupos es HaploGrep. Esta aplicación está basada en Phylotree y actualizada periódicamente con datos obtenidos alrededor del mundo. Para utilizarla se puede recurrir a cualquier segmento del genoma mitocondrial, generando los diez mejores resultados de la posición de la secuencia introducida en un haplogrupo determinado, ofreciendo una visualización interactiva de los resultados y recomendaciones de qué polimorfismos se deberían analizar para mejorar la exactitud del resultado (Weissensteiner et al., 2016).

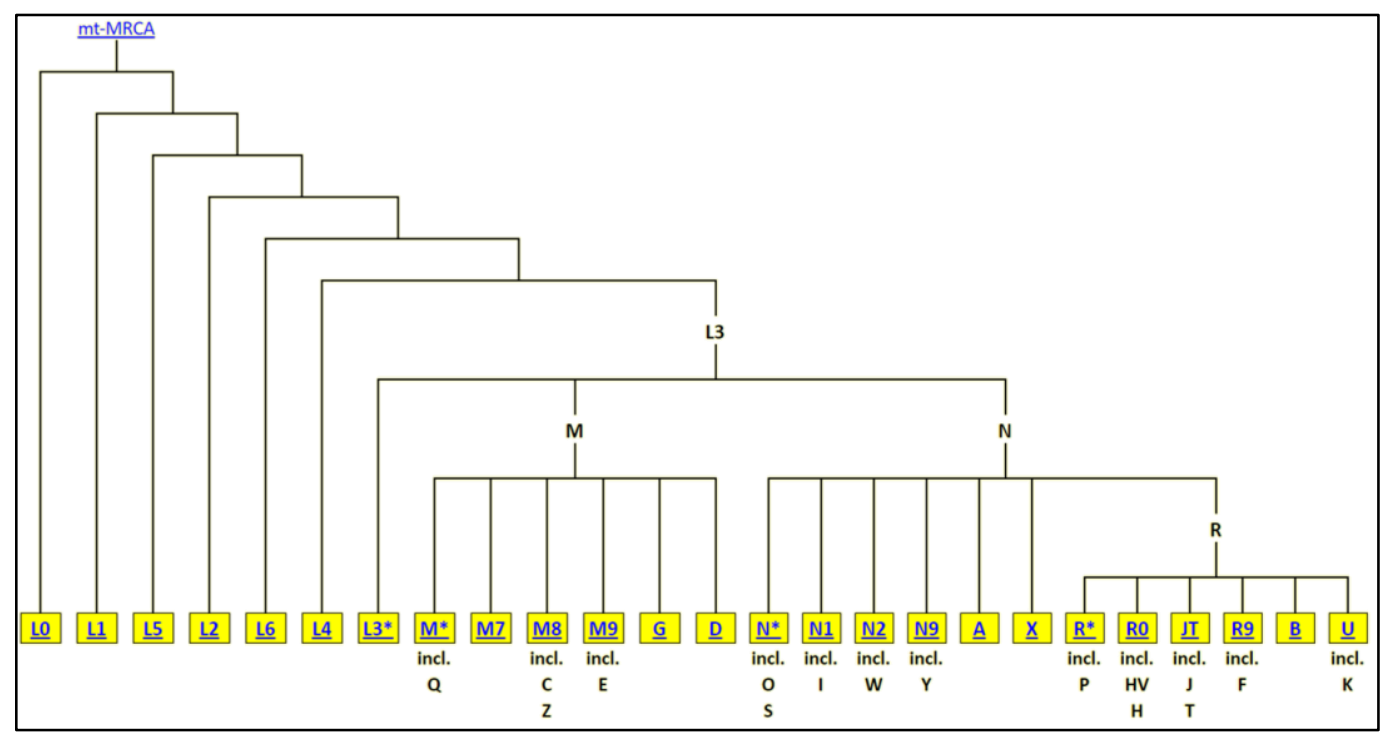

Figura 5. Árbol filogenético con haplogrupos de ADN mitocondrial (van Oven, 2009)

Finalmente, ya hemos adelantado que la secuenciación del gen que codifica el citocromo B se ha utilizado para identificar ADN no humano y la especie a la que pertenece (Kocher et al., 1989). En la página web de National Center for Biotechnology Information (NCBI) podemos encontrar el genoma de diversas especies, animales y vegetales (National Center for Biotechnology Information, s. f.). En el análisis de ADN no humano resultan especialmente útiles los algoritmos de alineación de secuencias por pares (BLAT, por sus siglas en inglés), en los que se introduce una secuencia dada, el programa la compara con las disponibles en su base de datos, y devuelve la o las especies con las que hay coincidencia. Herramientas de este tipo son Ensembl, 
dedicada al estudio de vertebrados (Hubbard et al., 2002), y UCSC Genome Browser, especializada en primates y vertebrados terrestres (Kent et al., 2002).

\section{El análisis de ADN mitocondrial en restos óseos antiguos.}

Una vez establecido el potencial identificador que tenía el ADN, el propio Jeffreys se preocupó por averiguar de qué tipo de muestras podía llegar a obtenerse, viendo que su metodología inicial daba problemas en unos restos esqueléticos de ocho años de antigüedad por obtenerse muy poco ADN, estando el mismo además degradado, desarrollando lo que posteriormente derivaría en la metodología de identificación basada en STRs, con lo que sí que consiguió un resultado identificativo (Hagelberg, Gray, \& Jeffreys, 1991). La recientemente descubierta secuenciación de Sanger para el ADN mitocondrial motivó probar la misma en los restos esqueléticos, viéndose que en los dientes el ADN se preservaba mucho mejor que en otros huesos (Ginther, Issel-Tarver, \& King, 1992). Identificando restos óseos de la Guerra de Vietnam, se vio que las muestras de huesos largos presentaban un ADNmt con un mayor grado de degradación que los dientes, al tiempo que se acentuaba la acción de los inhibidores de la polimerasa, consiguiendo identificar los restos amplificando pequeños fragmentos solapantes del ADNmt (M. M. Holland et al., 1993). La utilidad del análisis de ADN en restos óseos antiguos es diversa: desapariciones, identificación de víctimas de atentados terroristas o de grandes catástrofes, identificación de restos de fosas comunes de conflictos bélicos, procesos civiles de filiación, adopciones irregulares (Barrio-Caballero, 2012); pero el análisis no está exento de problemas y cuestiones que todavía no han podido resolverse, entre ellas el análisis de restos óseos antiguos con la finalidad de identificar al individuo. En el presente epígrafe vamos a ahondar en esta cuestión.

\subsection{Consideración de ADN antiguo.}

El primer problema con el que nos podemos tropezar es la propia formulación del mismo, y es que, ¿qué se considera ADN antiguo?

En este sentido, las opiniones de la comunidad científica son variadas, si bien pueden dividirse en dos grupos: los que consideran ADN antiguo como cualquier estudio del material genético realizado sobre organismos muertos (Hofreiter, Serre, Poinar, Kuch, \& Pääbo, 2001), mientras que otros entienden como ADN antiguo el obtenido de especímenes de museo, fósiles, y en general organismos ya extintos (Pevsner, 2009). Si bien es cierto que determinados autores, como el sueco Svante Pääbo, uno de los máximos exponentes en la materia, utiliza el mismo término para referirse a ambos grupos de casos indistintamente, tanto para organismos ya extintos (Krause \& Pääbo, 2016) como para organismos simplemente muertos, aunque también están los que separan $\mathrm{ADN}$ forense de $\mathrm{ADN}$ antiguo, pese a que compartan las mismas técnicas, diferenciándose en su finalidad (Graham, 2007). 
Si bien esta discusión tiene escasa utilidad en la práctica, no está de más intentar proporcionar una respuesta al dilema. En este sentido, podemos colegir que ADN antiguo sería el estudio del material genético de cualquier muestra no viva que se encuentre en un estado de degradación tal que las técnicas rutinarias de investigación de ADN no permitan obtener un resultado, incluyendo las siguientes categorías (Montiel Duarte, 2003):

1) ADN forense. Obtenido de todo tipo de muestras, con la finalidad de auxiliar al Derecho en alguna cuestión.

2) ADN envejecido. Obtenido de material biológico archivado, incluido en parafina, de cortes histológicos, o similar.

3) ADN antiguo. Obtenido de muestras del ámbito arqueológico y paleoantropológico o especímenes de museo.

4) ADN geológicamente antiguo. Obtenido de muestras fosilizadas con millones de años de antigüedad.

Mención especial requiere lo que podríamos denominar la frontera de los 20 años, que se corresponde con la primera pregunta formulada por el Juez o Jueza de Instrucción cuando se encuentran unos restos óseos, y es si los restos hallados tienen más de 20 años. Esta preocupación tiene su fundamento en el artículo 131.1 del Código Penal (Ley Orgánica 10/1995, de 23 de noviembre), que establece la prescripción de los delitos a los veinte años de su comisión cuando la pena prevista para los mismos sea de quince o más años. Cabe plantearse cómo se resuelven a su vez estas preguntas, pero eso es materia para otra discusión.

\subsection{El problema de la conservación.}

Siguiendo la discusión que acabamos de plantear, el hilo conductor que vertebra el estudio del ADN antiguo es el problema de su preservación. Abrimos este apartado con las consideraciones del propio Jeffreys, que observó la problemática del análisis de ADN cuando la muestra consistía en un hueso, observando el problema de la inhibición de la PCR. En el propio organismo vivo el ADN puede sufrir varios tipos de daños con relativa frecuencia, pero estas alteraciones cuentan con diversos mecanismos de reparación en el propio individuo; es después de la muerte cuando los mecanismos de reparación cesan su función, pero no así la degradación del material genético (Shapiro \& Hofreiter, 2012).

Es después de la muerte celular cuando empieza una verdadera prueba de contrarreloj para el analista: las nucleasas (enzimas presentes en el propio organismo cuya actividad rompe los enlaces fosfodiéster establecidos entre las bases nitrogenadas del material genético) entran en acción combinadas con la acción de los microorganismos, que digieren el ADN, actuando ambos

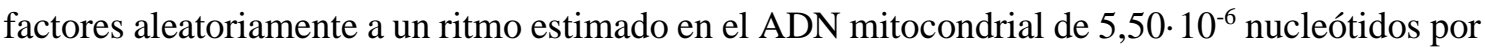
año transcurrido (Allentoft et al., 2012), como puede verse en la figura 6. 

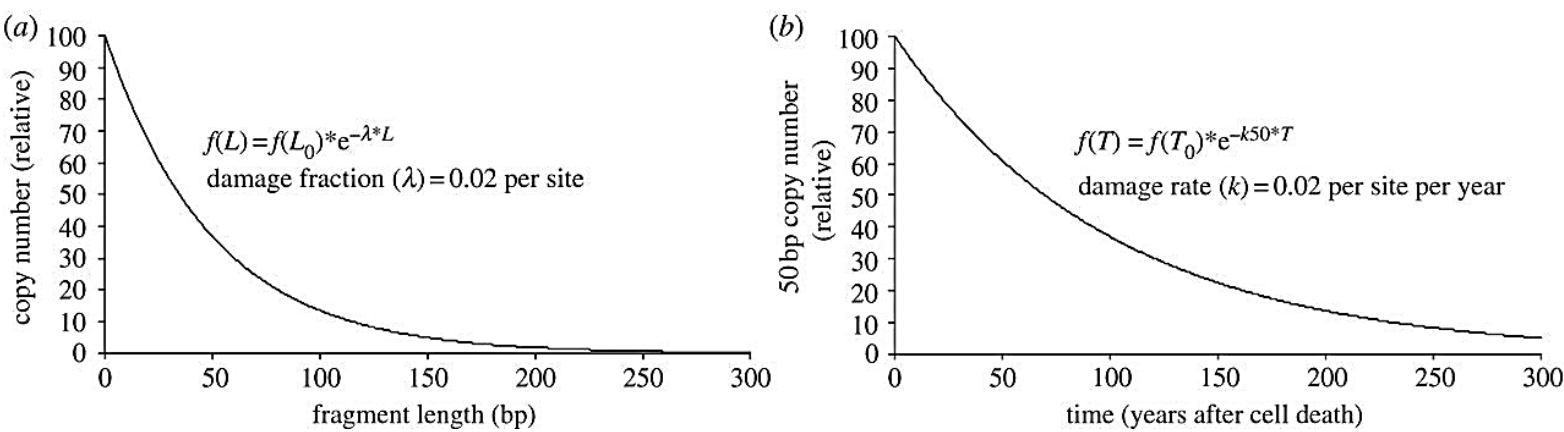

Figura 6. Degradación natural del ADN, que sigue un declive exponencial (Allentoft et al., 2012).

Por supuesto, no son únicamente estos mecanismos los que intervienen en la conservación del ADN. Puede ocurrir que un tejido se deshidrate muy rápidamente y no actúen ni las nucleasas ni la acción bacteriana, pero aun así el ADN se seguirá degradando, aunque a un ritmo más pausado, debido a los siguientes efectos (Pääbo et al., 2004):

A) Rotura de enlaces. Debida a la acción degradativa de microorganismos, la acción post mortem de enzimas nucleasas, u otros procesos químicos; reduce la cantidad y el tamaño del ADN.

B) Lesiones oxidativas. Se producen daños producidos por reacciones de reducción-oxidación en las bases o en la desoxirribosa, lo que resulta en una fragmentación de la base nitrogenada o de la pentosa, en definitiva, se modifica el nucleótido.

C) Cruce de ADN. Los fragmentos de ADN reaccionan entre sí o con otras moléculas y forman enlaces nuevos.

D) Lesiones hidrolíticas. La pérdida del grupo amino transforma la adenina en hipoxantina (forma degradativa intermedia), la citosina en uracilo, la 5-metil-citosina en timina, y la guanina en xantina; transformaciones todas ellas con un enorme potencial de cambiar la secuencia del material genético.

E) Reacciones de Maillard. Distintas reacciones químicas de naturaleza hoy todavía incierta, bien conocidas en Química Alimentaria por dar el color marrón a cervezas, carnes o galletas, pero que implican la reacción entre glúcidos y proteínas, y ocurren también con el ADN, degradándolo.

Estos procesos están motivados por la acción, normalmente combinada y desigual, de diversos factores (Barrio-Caballero, 2012):

1) Temperatura. Probablemente el factor que más condiciona la conservación del ADN, las bajas temperaturas favorecen su conservación debido a que ralentizan las distintas reacciones que acabamos de ver, mientras que las altas temperaturas precisamente favorecen estos procesos. A su vez, las altas temperaturas pueden deshidratar el tejido y preservar el material genético de determinados procesos degradativos. 
2) Humedad. La acción disolvente del agua favorece la presencia de sustancias orgánicas que tengan actividad inhibidora de la ADN polimerasa, al tiempo que favorece la degradación oxidativa e hidrolítica.

3) pH. Un pH ácido altera el estado de oxidación del fósforo contenido en el fosfato del ADN, lo que a pH muy bajo acaba por fragmentarlo en sus unidades más elementales (Young, Rawlence, Weyrich, \& Cooper, 2014). Por el contrario, un pH alcalino afecta los puentes de hidrógeno, provocando a valores muy altos de $\mathrm{pH}$ una separación de las doble cadena por fenómenos de deprotonación (Ageno, Dore, \& Frontali, 1969). Valores de pH neutro o ligeramente alcalinos, cercanos al fisiológico, favorecen la preservación del ADN (Lindahl, 1993).

4) Componentes del suelo. Los distintos minerales presentes en el suelo tienen un efecto desigual en el ADN. Por ejemplo, la arena, compuesta fundamentalmente por cuarzo, tiene capacidad absorbente, secuestrando el ADN y protegiéndolo de la acción de otros agentes degradantes (Romanowski, Lorenz, \& Wackernagel, 1991). El mismo fenómeno sucede con las arcillas, viéndose que el análisis del suelo en busca de ADN es muy prometedor (Alvarez, Khanna, Toranzos, \& Stotzky, 1998). Pero, sobre todo hay que tener en cuenta la capacidad degradativa de las sustancias húmicas, un grupo heterogéneo de sustancias derivadas de la descomposición de restos animales y vegetales, que tienen una acción inhibidora de la PCR (que veremos a continuación) y la capacidad de formar enlaces con el ADN (Zipper et al., 2003), lo que incluso puede llegar a protegerlo de la acción degradativa de otras sustancias (Crecchio \& Stotzky, 1998).

5) Inhibidores de la PCR. Pese a que la naturaleza de la acción de las sustancias que influyen negativamente en la amplificación del ADN es, a día de hoy, incierta, lo que está claro es que su presencia influye negativamente en el análisis del mismo. Suelen ser compuestos derivados del suelo o de la propia degradación orgánica. Los ácidos húmicos y fúlvicos del suelo tienen una acción inhibidora de las enzimas biológicas, afectando negativamente a la reacción de la PCR. Los residuos derivados de la porfirina, sustancia presente en hojas vegetales, sangre, y tejidos blandos, tienen también una actividad inhibidora de la PCR.

\subsection{La importancia de la muestra de restos óseos.}

A nadie escapa que la importancia del estudio de los restos óseos cuando se trata el asunto del ADN antiguo radica en el hecho de que es la estructura biológica que más y mejor permanece en el tiempo desde la muerte del individuo, exceptuando algunos escenarios concretos como el permafrost (véase el caso de Ötzi) o los pantanos o ciénagas, en los que la acidez de la turba puede hacer desaparecer los huesos.

El tejido óseo no deja de ser tejido conectivo denso especializado, compuesto igualmente de células embebidas en una matriz, cuya calcificación es la que le confiere sus propiedades 
diferenciadoras (relativamente livianos, gran dureza, resistencia, elasticidad), cuyas funciones principales son la estructural, la protectora y la homeostasis con respecto al calcio. Desde un examen macroscópico puede apreciarse que el hueso se organiza de dos maneras diferentes, teniendo por un lado el tejido óseo compacto o cortical, visto como una masa sin espacios, y el tejido óseo esponjoso o trabecular, compuesto por finas hojas o trabéculas que se entrecruzan en diferentes direcciones. Casi todos los huesos se componen de ambos tipos de tejido óseo, aunque en proporciones diferentes: por ejemplo, en los huesos largos, la diáfisis (zona más medial) presenta una mayor composición de hueso cortical, que envuelve el canal medular, mientras que las epífisis (zonas más distales) se componen principalmente de hueso esponjoso. A nivel histológico el hueso contiene como unidades fundamentales los sistemas de Havers, (ver figura 7), cilindros en los que la matriz ósea se dispone a modo de láminas concéntricas, situándose las células óseas u osteocitos en unas lagunas contenidas entre estas láminas de matriz ósea. La matriz ósea se compone fundamentalmente de fibras de colágeno y osteocalcina, que se une a los cristales de hidroxiapatita $\left(\mathrm{Ca}_{10}\left(\mathrm{PO}_{4}\right)_{6}(\mathrm{OH})_{2}\right)$, componente principal del hueso. Los células óseas son fundamentalmente tres: los osteoblastos (generadoras de hueso) los osteoclastos (degradadoras de hueso) y los osteocitos, verdaderas células óseas, que no son más que osteoblastos que quedan incluidos en el hueso cortical, y cuya función es la de mantenimiento del tejido óseo (Brüel, Christensen, Tranum-Jensen, Qvortrup, \& Geneser, 2012)

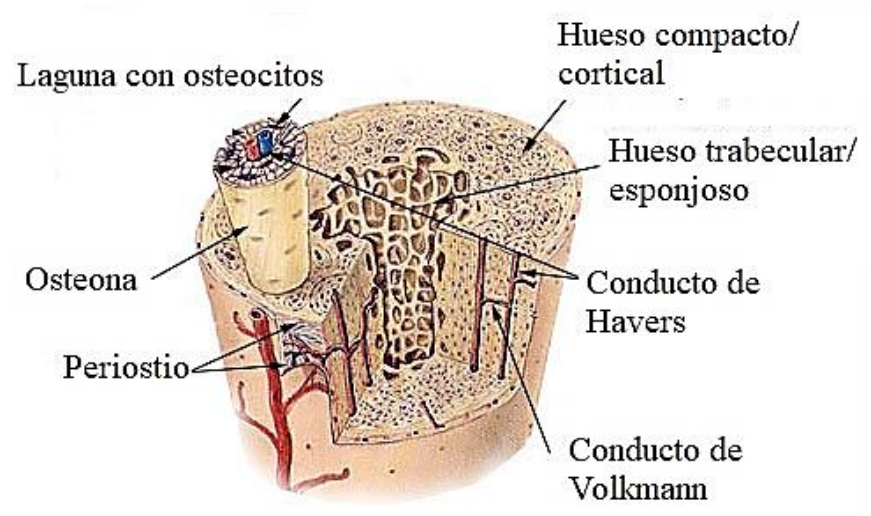

Figura 7. Esquema del tejido óseo cortical y trabecular. Fuente: Wikipedia.

De lo visto anteriormente podríamos pensar que la mejor zona del hueso para obtener ADN con el que poder hacer una identificación es la médula ósea, el centro esponjoso en el que se producen las células sanguíneas. El problema es que ese hecho tampoco pasa desapercibido a los microorganismos, productores de esas reacciones nucleasas que veíamos antes. Es por ello que la zona que se tomará para el análisis de ADN es la de hueso cortical, que contiene osteocitos aislados en lagunas de hueso cortical, lo que los aislaría parcialmente de microbios y sustancias químicas, preservando con ello el material genético. 
Una vez establecido qué parte del hueso es la que se analizará, la pregunta que nos asalta es, precisamente, de qué pieza ósea vamos a tomar la muestra. De un estudio de análisis de STRs realizado sobre 25361 huesos y dientes procedentes de tres momentos diferentes: el conflicto armado de Bosnia y Herzegovina de 1992, la caída de Srebrenica de 1995, y el conflicto de Kosovo de 1999. Se observó que son las muestras de fémur y las muestras de dientes las que mejor ratio tienen de conseguir un resultado en el análisis de ADN, mientras que la clavícula, el cúbito o el radio son los que menos resultados arrojan, como se refleja en la figura 8 (Miloš et al., 2007). Generalmente, el fémur es el hueso más pesado y resistente del cuerpo, pudiendo confundirse si está fragmentado con la tibia o el húmero, y que aporta mucha información antropológica valiosa para la estimación del sexo, la edad, o la estatura (Burns, 2007).

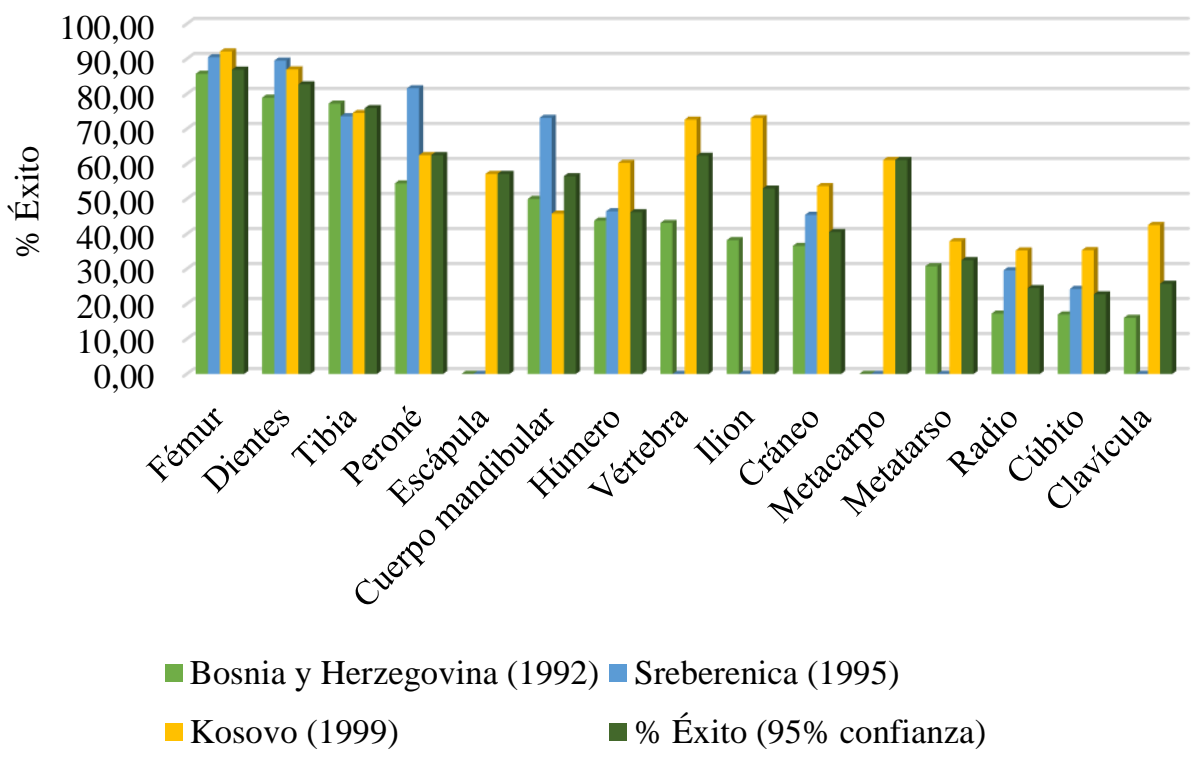

Figura 8. Ratio de obtención de un perfil por tipo de hueso. Fuente: Elaboración propia, a partir de Miloš et al., 2007.

Mención especial requiere un pormenorizado estudio histológico de las piezas dentales, que pueden ser deciduos, presentes en los primeros años del individuo, siendo posteriormente reemplazados por la dentición permanente, ambas de similar composición, y cuya erupción es bastante estable en las diferentes poblaciones, permitiendo el desarrollo de atlas para la estimación de la edad. Los dientes se componen fundamentalmente de una corona, que sobresale de la encía, recubierta por esmalte, y una raíz, incrustada en el alvéolo del maxilar o del mandibular, con un espacio interior denominado cavidad pulpar, que incluye ramificaciones vasculares y nerviosas, y es por tanto donde va a encontrarse el ADN que podamos analizar. Rodeando la cavidad pulpar está la dentina, más gruesa en la corona, donde se encuentra rodeada del esmalte. Esta estructura especial (figura 9), que protege enormemente la cavidad pulpar hace que los dientes sean particularmente propicios para el análisis de ADN. 


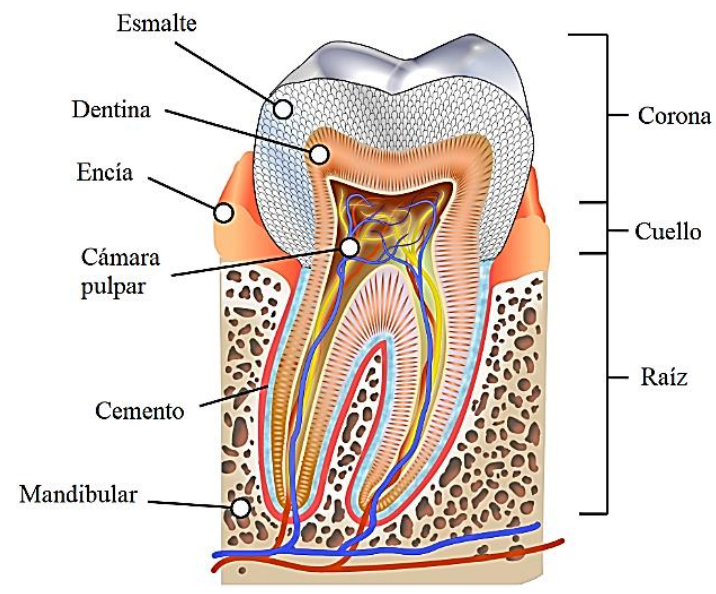

Figura 9. Estructura del diente. Fuente: Wikipedia

Los huesos son, por tanto, una fuente muy valiosa de ADN para identificación humana, pero dados los efectos de la degradación del ADN, la clave está en conseguir aislar la cantidad suficiente de ADN para hacer el análisis. En este sentido, se están estudiando las posibilidades de obtener mayor cantidad de ADN y de mejor calidad, a lo que un estudio realizado sobre el hueso petroso (región del cráneo que contiene el canal auditivo), el fémur y los dientes del mismo esqueleto. Se observó que dicho hueso craneal contenía más cantidad de ADN y mejor preservado, debido presumiblemente al alto grado de compactación ósea de esta zona, presentando además la ventaja de que puede extraerse con bisturí sin alterar gravemente la morfología del cráneo, y por extensión los estudios antropológicos que pudieran hacerse del mismo (Pilli et al., 2018). Otro estudio ha apuntado a que se puede obtener también ADN en buen estado de conservación de las raíces de los dientes, lo que puede resultar útil en caso de que no se disponga de la cámara pulpar (Dutra Corrêa et al., 2017). No obstante, estos estudios se han realizado sobre marcadores de ADN nuclear, siendo menester realizar pruebas sobre ADN mitocondrial, resultando necesario un análisis más completo de qué huesos resultan idóneos para el análisis de $\mathrm{ADN}$, y si esta cuestión depende únicamente de la estructura ósea a nivel anatómico o tisular, o si, por el contrario, tiene que ver con el sexo del individuo, la población, el tipo de enterramiento, las características del suelo, la conservación que se haga posteriormente de la muestra, etc.

Sea cual sea, la toma de muestra es un proceso crucial, pues con unas mínimas precauciones puede facilitar mucho el trabajo posterior en el laboratorio, dado que una manipulación incorrecta de la muestra puede, incluso, eliminar la posibilidad de análisis. Llevar guantes durante la excavación, cepillar los huesos en lugar de lavarlos con agua, y almacenarlos en un lugar fresco y seco inmediatamente a su excavación, pueden hacer una gran diferencia, máxima si se usa mascarilla y mono, se limpian las herramientas entre muestras, se protege el lugar de los elementos, se entrena al personal y se registra toda la actividad (Llamas et al., 2017). 


\subsection{Criterios de autenticidad del análisis de ADN antiguo.}

Las dificultades anteriormente descritas tienen varias consecuencias para el análisis del ADN antiguo, siendo por tanto imperativo disponer de unos criterios que garanticen la validez tanto del proceso como del resultado del mismo, criterios que orbitan alrededor de los mismos tres puntos: controles de extracción en paralelo con las extracciones de ADN antiguo para verificar la presencia o ausencia de contaminación de los reactivos y soluciones durante el procedimiento, amplificar las mismas secuencias de ADN en varios extractos del mismo individuo, y la existencia de una correlación inversa entre el grado de conservación de la muestra y el tamaño del amplicón obtenido (Pääbo et al., 2004). Estos criterios se han visto ampliados hasta llegar a la lista siguiente (Poinar, 2003):

1) Trabajar en un área físicamente aislada. Para evitar la contaminación, es esencial que el trabajo se desarrolle en un laboratorio aislado y dedicado exclusivamente a muestras con bajo número de copias de $\mathrm{ADN}$, si es posible, en otras dependencias o instalaciones en las que no se desarrolle trabajo con material genético. La extracción y amplificación del ADN serían efectuados en este espacio, trasladando las etapas posteriores al laboratorio habitual.

2) Control de amplificación de la PCR. Es conveniente hacer controles periódicos de la amplificación mediante blancos que contengan únicamente agua y los reactivos necesarios para la PCR, al mismo tiempo que en cada análisis se introduce un control negativo, llevando en todo momento un registro de las contaminaciones detectadas.

3) Comportamiento molecular. Los resultados obtenidos deben estar acordes al estado de degradación del $\mathrm{ADN}$ de la muestra: no cabe esperar, por ejemplo, obtener una secuenciación completa de unos restos muy antiguos, lo que se debería más probablemente a una contaminación que a un análisis exitoso.

4) Cuantificación. El número de copias de ADN contenidas en la muestra debe estimarse, ya sea por PCR en tiempo real o PCR competitiva, de modo que, si el número de moléculas presentes en el extracto es menor de 1000, puede llegar a ser imposible excluir la posibilidad de contaminación, especialmente con ADN humano.

5) Reproducibilidad. Los resultados deben poder repetirse sobre los mismos u otros extractos de ADN del mismo espécimen con el que se está trabajando.

6) Clonación. Debe verificarse la secuenciación de los productos de PCR mediante la clonación de los productos de amplificación y secuenciación (al menos diez) para determinar si ha habido contaminación y en qué cantidad.

7) Repetitividad. Implica la extracción, amplificación y secuenciación de muestras separadas del mismo individuo por laboratorios independientes.

8) Preservación bioquímica. Se puede obtener información indirecta sobre el estado de conservación del ADN midiendo la cantidad, composición y alcance de los cambios 
ocurridos en los aminoácidos y otros residuos de la muestra. En el caso de que las muestras sean para análisis forense, es también recomendable examinar otros marcadores como la oxidación de ácidos grasos o peroxidación lipídica.

9) Restos asociados. En restos humanos con restos animales asociados, la conservación de ADN en estos últimos puede resultar muy halagüeña en lo que a la conservación del ADN humano se refiere, por lo que también es aconsejable su amplificación por PCR.

10) Sentido filogenético. Las secuencias obtenidas deberían situarse en un árbol filogenético con otros haplotipos conocidos con el fin de asegurar la autenticidad de los resultados, especialmente cuando se detectan pseudogenes mitocondriales (información de ADN mitocondrial no codificante contenida en el ADN nuclear).

\section{Procedimiento de análisis de ADN mitocondrial en restos óseos.}

Ahora que ya sabemos, cómo tenemos que proceder, veamos las técnicas concretas que tenemos que aplicar. El estado en el que vamos a encontrar las muestras, mínimas o muy degradadas, hace que el procedimiento analítico sea especialmente costoso y elaborado (Álvarez et al., 2001). El procedimiento analítico puede dividirse en cuatro etapas básicas: preparación de la muestra, amplificación del ADN, secuenciación, y análisis e interpretación de resultados. La principal diferencia que tiene el análisis de ADN mitocondrial con respecto al análisis de rutina de ADN nuclear es la secuenciación, precedida y seguida de procesos de purificación. Veamos, uno por uno, los distintos pasos.

\subsection{Preparación de la muestra.}

Tratándose de huesos y dientes es necesario hacer una limpieza previa de las piezas, limpiando la superficie externa de las mismas con una lima o minitaladro tipo Dremel, siendo de especial utilidad en este caso el empleo de una cabina de extracción de huesos, cuyo objetivo principal es aislar todavía más la muestra y evitar la obstrucción de la campana de flujo laminar en la que se trabaje, consistiendo la misma en una urna de metacrilato con tapa extraíble y orificios laterales para introducir los brazos, una Dremel, útil tanto para cortar, como para lijar o pulverizar, y un aspirador conectado a la urna que aspire los residuos generados por la operación (figura 10).

Junto con la eliminación de la superficie hay descritas otras dos técnicas de descontaminación: irradiación con luz ultravioleta y lavado químico (Kaestle \& Horsburgh, 2002). El lavado químico mediante la sumersión de las piezas en lejía diluida o agua destilada puede no ser suficiente para eliminar todo el ADN exógeno de los poros de la muestra, pero sí como para que las sustancias químicas penetren y afecten al ADN de la misma; la irradiación con ultravioleta pierde mucha eficacia si la muestra tiene una forma irregular, del mismo modo que puede no penetrar de manera suficiente la superficie de la muestra y destruir el ADN exógeno, pero sí que puede ser lo suficientemente potente como para destruir el ADN endógeno. Esto se 
debe al efecto ionizante de la luz ultravioleta, sobre todo de la luz ultravioleta $\mathrm{C}(10-400 \mathrm{~nm})$, capaz de fragmentar las cadenas de ADN (Hall \& Ballantyne, 2004).

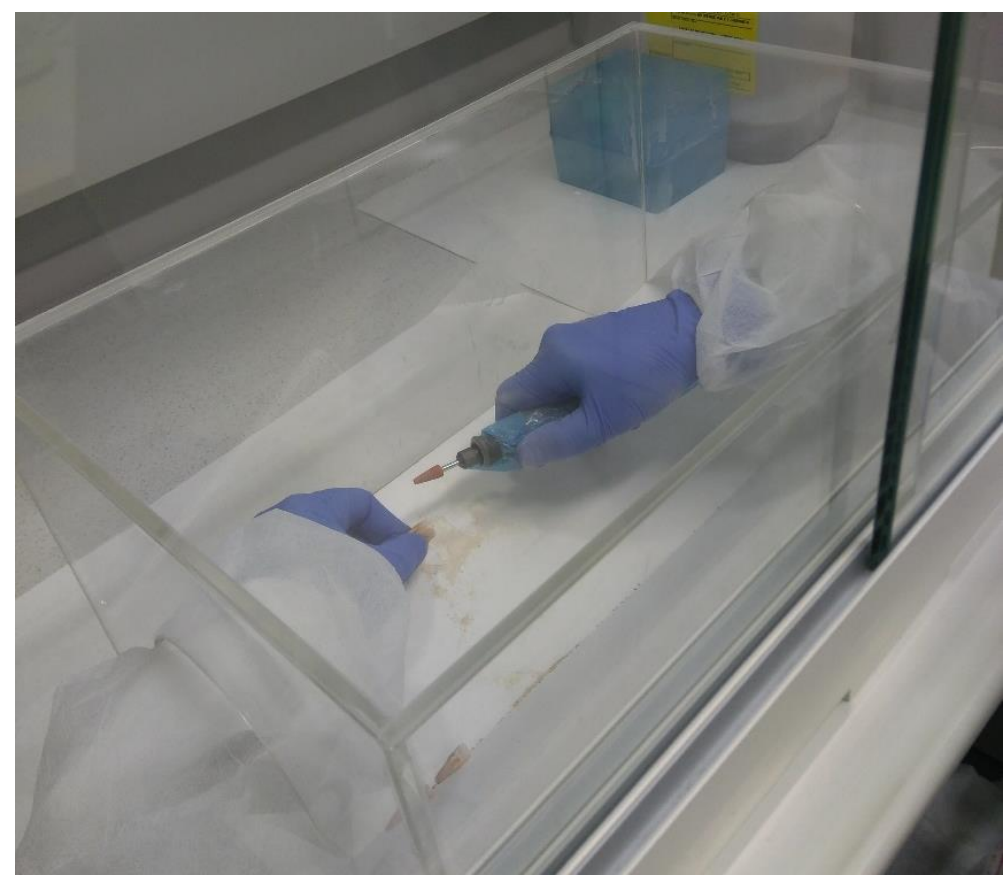

Figura 10. Lijado de diente en urna de metacrilato.

\subsection{Extracción del ADN.}

Hay distintos protocolos de extracción, viniendo la elección de los mismos dada por el tipo de muestra, el estado en el que se encuentra, o la cantidad de la misma. Esta fase tiene el objetivo de romper la matriz celular y liberar el ADN del mismo. De las distintas posibilidades que podemos manejar, caben destacar cuatro (Barrio-Caballero, 2012):

A) Extracción con fenol:cloroformo. Adaptación del procedimiento estándar, las muestras son digeridas con proteinasa $\mathrm{K}$ (que rompe las membranas celulares) y un detergente (Triton $\mathrm{X}-100$, SDS, u otro) mezclando el digerido con fenol:cloroformo:alcohol isoamílico (mezcla 25:24:1), quedando el ADN en la fase acuosa, que se filtra por centrifugación.

B) Sílice-sal. Al pulverizado de hueso o diente se añade una solución de extracción con EDTA (ácido etilendiaminotetraacético), se deja incubar y se añade GuSCN (tiocianato de guanidinio) concentrado con acetato sódico y una suspensión de gel de sílice (silicato sódico), a la que se une el ADN, incubándolo todo en la oscuridad. Una vez descartado el sobrenadante, se lava la sílice con buffer y etanol, para luego resuspender el ADN con TE (Tris-EDTA).

C) Desmineralización-sílice. Método variante del anterior, centrado en desmineralizar completamente la matriz ósea con EDTA, sarkosyl (sodio lauril sarcosinato) y proteinasa $\mathrm{K}$, se filtra, $\mathrm{y}$ se purifica e incluso repurifica mediante kits comerciales. 
D) Fishing. El pulverizado se somete a una extracción estándar con EDTA, SDS y proteinasa K y el sobrenadante se somete repetidas veces a un buffer de unión y lavado, se filtra, se incuba la muestra con primers marcados con biotinas, para luego inmovilizar el ADN con partículas magnéticas recubiertas de estreptadivina, proteína que presenta una gran afinidad por la biotina. Se hacen diversos lavados y se resuspende el ADN en agua o TE.

Como todo en la vida, cada protocolo tiene sus ventajas y sus inconvenientes, los cuáles se resumen en la tabla 3 .

Tabla 3. Comparativa de los distintos protocolos de extracción de ADN en restos óseos (BarrioCaballero, 2012).

\begin{tabular}{|c|c|c|c|c|}
\hline & $\begin{array}{l}\text { Fenol: } \\
\text { cloroformo }\end{array}$ & Sílice-sal & $\begin{array}{l}\text { Desmineralización- } \\
\text { sílice }\end{array}$ & Fishing \\
\hline Ventajas & $\begin{array}{l}\text { Mayor } \\
\text { rendimiento. } \\
\text { Mayor } \\
\text { pureza. } \\
\text { Protocolo } \\
\text { estándar. }\end{array}$ & $\begin{array}{l}\text { Mayores } \\
\text { resultados. } \\
\text { Eliminación de } \\
\text { inhibidores. } \\
\text { Automatización. }\end{array}$ & $\begin{array}{l}\text { Mayores resultados. } \\
\text { Elimina inhibidores. } \\
\text { Procesado a gran } \\
\text { escala. }\end{array}$ & $\begin{array}{l}\text { Elimina } \\
\text { inhibidores. } \\
\text { Rápido. } \\
\text { Gran número de } \\
\text { muestras. } \\
\text { Automatización. }\end{array}$ \\
\hline Inconvenientes & $\begin{array}{l}\text { No elimina } \\
\text { inhibidores. } \\
\text { Tóxico. } \\
\text { Largo. }\end{array}$ & $\begin{array}{l}\text { Largo. } \\
\text { Complejo. }\end{array}$ & $\begin{array}{l}\text { Contaminación } \\
\text { cruzada posible. } \\
\text { Automatización no } \\
\text { validada. }\end{array}$ & $\begin{array}{l}\text { Menor } \\
\text { rendimiento. } \\
\text { Coste elevado. }\end{array}$ \\
\hline
\end{tabular}

Con todo lo dicho podemos quedarnos con la realización de una pulverización con Freezer/Mill@, aparato que usa nitrógeno líquido, en el que las muestras a pulverizar se introducen en viales que contienen un cilindro metálico y mediante un proceso electromecánico permite llevar a cabo la pulverización. Como alternativa sin nitrógeno líquido tenemos el TissueLyser II de Qiagen, un agitador en el que las muestras se encierran en viales metálicos con esferas metálicas que se agitan muy rápidamente durante poco tiempo, pulverizando las muestras sin generar excesivo calor que pudiese altear la muestra. Tanto los viales como todos sus accesorios deben ser sometidos a limpieza con lejía al 10\% y expuestos a luz UV durante 15 minutos. Pese a que la bibliografía muestra que el método de sílice-sal es el que mejor rendimiento tiene (Rohland \& Hofreiter, 2018), nos centraremos en el protocolo de fenol:cloroformo por ser el que mejor supera un balance de costes-beneficios y ser el más frecuente en laboratorios forenses. El procedimiento sería el siguiente:

1) Preparar un control negativo de extracción pasando un hisopo estéril por el vial de TissueLyser II introduciéndolo en un Eppendorf y añadiendo $4125 \mu \mathrm{l}$ de EDTA 0,5M (a pH 8), $375 \mu \mathrm{l}$ de proteinasa $\mathrm{K}(1 \mathrm{mg} / 100 \mu \mathrm{l}), 200 \mu \mathrm{l}$ de DTT $1 \mathrm{M}$ y $300 \mu \mathrm{l}$ de SDS (dodecil sulfato de sodio) al $10 \%$.

2) Dependiendo de la muestra escogida: 
a) Hueso. Cortar un fragmento de hueso cortical de $2 \times 1 \mathrm{~cm}$ con minitaladro, empleando un disco nuevo con cada muestra. Limar la superficie externa con el propio minitaladro y hacer fragmentos más pequeños, colocándolos en el vial de TissueLyser II.

b) Diente. Limar la superficie con el minitaladro, eliminando la máxima cantidad posible de raíz y esmalte.

3) Programar dos ciclos de $300 \mathrm{~Hz}$ de 1 minuto. Nos deberá quedar un pulverizado fino. Realizar una nueva etapa si es necesario.

4) Colocamos el pulverizado en papel de aluminio y pesamos 1 gramo de pulverizado en un tubo Falcon.

5) $4125 \mu \mathrm{l}$ de EDTA $0,5 \mathrm{M}(\mathrm{a} \mathrm{pH}), 375 \mu \mathrm{l}$ de proteinasa $\mathrm{K}(1 \mathrm{mg} / 100 \mu \mathrm{l}), 200 \mu 1$ de DTT 1 M y $300 \mu 1$ de SDS (dodecil sulfato de sodio) al 10\%. Incubar toda la noche en agitación a $56^{\circ} \mathrm{C}$.

6) Añadimos $4125 \mu \mathrm{l}$ de fenol:cloroformo:alcohol isoamílico (25:24:1), según la cantidad de buffer, agitamos 30 segundos hasta conseguir una emulsión e inmediatamente se centrifuga a $10000 \mathrm{~g}$.

7) Pasamos el sobrenadante a filtros Amicon Ultra-4 de $30 \mathrm{kDa}$ previamente hidratados con $100 \mu l$ de agua estéril, centrifugando los filtros 10 minutos a $500 \mathrm{~g}$. Centrifugar de nuevo si es necesario.

8) Añadimos $400 \mu \mathrm{l}$ de agua estéril y centrifugamos de nuevo.

9) Añadimos $100 \mu 1$ de agua estéril, colocamos el filtro invertido en un nuevo tubo Eppendorf, y centrifugamos 5 minutos a $1000 \mathrm{~g}$.

\subsection{Amplificación del ADN mitocondrial.}

En este paso hay también multitud de técnicas, que van a depender todas del estado de degradación de la muestra: en muestras recientes o de buena calidad es posible amplificar la región control completa, o incluso todo el genoma mitocondrial (recordemos el interés que puede tener el gen del citocromo B), pero si se sospecha que la muestra está degradada habrá que ir reduciendo los fragmentos en función del grado de degradación de la misma, a lo que tenemos las diferentes estrategias recogidas en la tabla 4, las cuales han ido desarrollándose desde finales de los años 90 (Wilson, DiZinno, Polanskey, Replogue, \& Budowle, 1995), y que han ido fundamentándose en el empleo de fragmentos cada vez más pequeños cuanto más degradada esté la muestra, al tiempo que los mismos vayan solapándose (Gabriel et al., 1999). En la figura 11 podemos ver un gráfico de los distintos primers y su relación entre sí y con las regiones hipervariables. 
Tabla 4. Estrategias de amplificación de ADN mitocondrial.

\begin{tabular}{|c|c|c|c|}
\hline \multicolumn{2}{|l|}{ Estrategia de amplificación } & Primers & $\begin{array}{l}\text { Tamaño } \\
\text { (pb) }\end{array}$ \\
\hline \multirow{4}{*}{$\begin{array}{l}\text { Región control completa (RCC) } \\
\text { (Álvarez et al., 2001; Lutz et al., } \\
\text { 2000) }\end{array}$} & RCC & L15996 - H619 & 1192 \\
\hline & $\begin{array}{l}\text { HV1 } \\
\text { HV2 }\end{array}$ & L15971 - H408 & 1006 \\
\hline & HV1 & L15996 (A1) - H16401 (B1) & 405 \\
\hline & HV2 & L29 (C1) - H389 (D1) & 360 \\
\hline \multirow{5}{*}{$\begin{array}{l}\text { Secuencias de Primers FBI } \\
\text { (Montesino \& Prieto, 2012) }\end{array}$} & HV1A & L15997 - H16395 & 437 \\
\hline & HV1B & L15997 - H17 & 629 \\
\hline & HV2A & L48 - H408 & 401 \\
\hline & HV2B & L16555 - H619 & 612 \\
\hline & HV3 & L350 - H619 & 310 \\
\hline \multirow{5}{*}{$\begin{array}{c}\text { Primer Set } \\
\text { (Loreille \& Irwin, 2015) }\end{array}$} & PS1 & $\begin{array}{l}\text { F15989/R16251 } \\
\text { F15971/R16258 }\end{array}$ & $\begin{array}{l}263 \\
288\end{array}$ \\
\hline & PS2 & $\begin{array}{l}\text { F16190/R16410-M19 } \\
\text { F16190/R16400 }\end{array}$ & $\begin{array}{l}221 \\
211\end{array}$ \\
\hline & PS3 & $\begin{array}{l}\text { F15/R285 } \\
\text { F15/R270 } \\
\text { F29/R270 } \\
\text { F29/R274 }\end{array}$ & $\begin{array}{l}271 \\
256 \\
242 \\
246\end{array}$ \\
\hline & PS4 & $\begin{array}{l}\text { F140/R389 } \\
\text { F155/R389 } \\
\text { F155/R381 } \\
\text { F155/R484 }\end{array}$ & $\begin{array}{l}250 \\
235 \\
227 \\
330\end{array}$ \\
\hline & PS5 & F16363/R16 & 233 \\
\hline \multirow{9}{*}{$\begin{array}{l}\text { MiniPrimer Set (Loreille \& Irwin, } \\
\text { 2015) }\end{array}$} & MPS1A & F15989/R16158 & 170 \\
\hline & MPS1B & $\begin{array}{l}\text { F16112/R16251 } \\
\text { F16112/R16237 }\end{array}$ & $\begin{array}{l}140 \\
126\end{array}$ \\
\hline & MPS2A & F16190/R16322 & 133 \\
\hline & MPS2B & $\begin{array}{l}\text { F16222/R16410-M19 } \\
\text { F16268/R16410-M19 } \\
\text { F16222/R16400 } \\
\text { F16268/R16400 }\end{array}$ & $\begin{array}{l}189 \\
143 \\
179 \\
133\end{array}$ \\
\hline & MPS3A & F34/R159 & 126 \\
\hline & MPS3B & F109/R240 & 132 \\
\hline & MPS4A & F151/R292 & 142 \\
\hline & MPS4B & F220/R389 & 170 \\
\hline & MPS5A & F16363/R16509 & 147 \\
\hline \multicolumn{4}{|c|}{ Secuencias de los primers } \\
\hline A1-L15997 & \multicolumn{3}{|c|}{ 5'-CAC CAT TAG CAC CCA AAG CT-3' } \\
\hline A2-L16159 & \multicolumn{3}{|c|}{ 5'-TAC TTG ACC ACC TGT AGT AC-3' } \\
\hline A4-L16209 & \multicolumn{3}{|c|}{ 5'-CCC CAT GCT TAC AAG CAA GT-3' } \\
\hline B1-H16391 & \multicolumn{3}{|c|}{ 5'-GAG GAT GGT GGT CAA GGG AC-3' } \\
\hline B2-H16237 & \multicolumn{3}{|c|}{ 5'-GGC TTT GGA GTT GCA GTT GAT-3' } \\
\hline
\end{tabular}




\begin{tabular}{|c|}
\hline B4-H16164 \\
\hline C1-L48 \\
\hline C2-L177 \\
\hline C3-L318 \\
\hline C4-L317 \\
\hline D1-H408 \\
\hline D2-H285 \\
\hline D4-H266 \\
\hline F15971 \\
\hline F15989 \\
\hline F16112 \\
\hline F16190 \\
\hline F16222 \\
\hline F16268 \\
\hline F16363 \\
\hline F16450 \\
\hline R16158 \\
\hline R16237 \\
\hline R16251 \\
\hline R16258 \\
\hline R16322 \\
\hline H16395 \\
\hline R16400 \\
\hline H16401 \\
\hline F16509 \\
\hline \\
\hline F165 \\
\hline \\
\hline
\end{tabular}

5'-TTT GAT GTG GAT TTG GGT TT-3' 5'- CTC ACG GGA GCT CTC CAT GC-3' 5'-TTA TTT ATC GCA CCT ACG TTC AAT-3' 5'-CCC CCC CCC CCC GCT-3' 5'-CCC CCC CTC CCC CCG C-3'

5'-CTG TTA AAA GTG CAT ACC GCC A-3' 5'-GGG GTT TGG TGG AAA TTT TTT G-3' 5'-GTT ATG ATG TCT GTG TGG AA-3' 5'-TTA ACT CCA CCA TTA GCA CC-3' 5'-CCC AAA GCT AAG ATT CTA AT-3' 5'-CAC CAT GAA TAT TGT ACG GT-3' 5'-CCC CAT GCT TAC AAG CAA GT-3' 5'-CCT CAA CTA TCA CAC ATC-3' 5'-CAC TAG GAT ACC AAC AAA CC-3' 5'-CCC CAT GGA TGA CCC CCC-3' 5'-GCT CCG GGC CCA TAA CAC TTG-3' 5'-TAC TAC AGG TGG TCA AGT AT-3' 5'-TGT GTG ATA GTT GAG GGT TG-3' 5'-GGA GTT GCA GTT GAT GT-3' 5'-TGG CTT TGG AGT TGC AGT TG-3' 5'-TGG CTT TAT GTA CTA TGT AC-3' 5'-CAC GGA GGA TGG TGG TCA AG-3' 5'-GTC AAG GGA CCC CTA TCT GA-3' 5'-TGA TTT CAC GGA GGA TGG TG-3' 5'-GAG GAT GGT GGT CAA GGG A-3' 5'-AGG AAC CAG ATG TCG GAT AC-3' 5'-CCC ACA CGT TCC CCT TAA AT-3' 5'-CAC CCT ATT AAC CAC TCA CG-3' 5'-TGA TAG ACC TGT GAT CCA TCG TGA-3' 5'-CCC GTG AGT GGT TAA TAG GGT-3' 5'-CTC ACG GGA GCT CTC CAT GC-3' 5'-GGG AGC TCT CCA TGC ATT TGG TA-3' 5'-GCA CCC TAT GTC GCA GTA TCT GTC-3' 5'-CCT GCC TCA TCC TAT TAT TTA-3' 5'-CTA TTA TTT ATC GCA CCT-3' 5'-TAT TTA TCG CAC CTA CGT TC-3' 5'-AAA TAA TAG GAT GAG GCA GGA ATC-3' 5'-TGC TTG TAG GAC ATA ATA AT-3' 5'-TAT TAT TAT GTC CTA CAA GCA-3' 


\begin{tabular}{|l|l|}
\hline R270 \\
\hline R274 \\
\hline R292 \\
\hline L350 \\
\hline R381 \\
\hline H389 \\
\hline F403 \\
\hline H408 \\
\hline R484 \\
\hline R569 \\
\hline R599 \\
\hline H619
\end{tabular}

5'-TGG AAA GTG GCT GTG CAG AC-3'
5'-TGT GTG GAA AGT GGC TGT GC-3'
5'-GTT ATG ATG TCT GTG TGG AA-3'
5'-ATT TTT TGT TAT GAT GTC T-3'
5'-GCA CTT AAA CAC ATC TCT GCC A-3'
5'-GCT GGT GTT AGG GTT CTT TG-3'
5'-CTG GTT AGG CTG GTG TTA GG-3'
5'-TCT TTT GGC GGT ATG CAC TTT-3'
5'-CTG TTA AAA GTG CAT ACC GCC A-3'
5'-TGA GAT TAG TAG TAT GGG AG-3'
5'-GGT GTG TTT GGG GTT TGG TTG-3'
5'-TTG AGG AGG TAA GCT ACA TA-3'
5'-GGT GAT GTG AGC CCG TCT AA-3'

No habrá escapado al lector la gran cantidad de primers existentes que, además, siguen diferente nomenclatura, pues no hay forma unánime para denominarlos, utilizando algunos autores las letras " $\mathrm{F}$ " o "R" para referirse a la dirección de amplificación (forward o reverse), mientras que otros se inclinan por las letras "L" o "H (light o heavy), que alude a la cadena de ADN mitocondrial en la que hibridan, siendo el número la base, según la secuencia de Cambridge, donde los primers empiezan o terminan de hibridar (extremo 5' o 3').

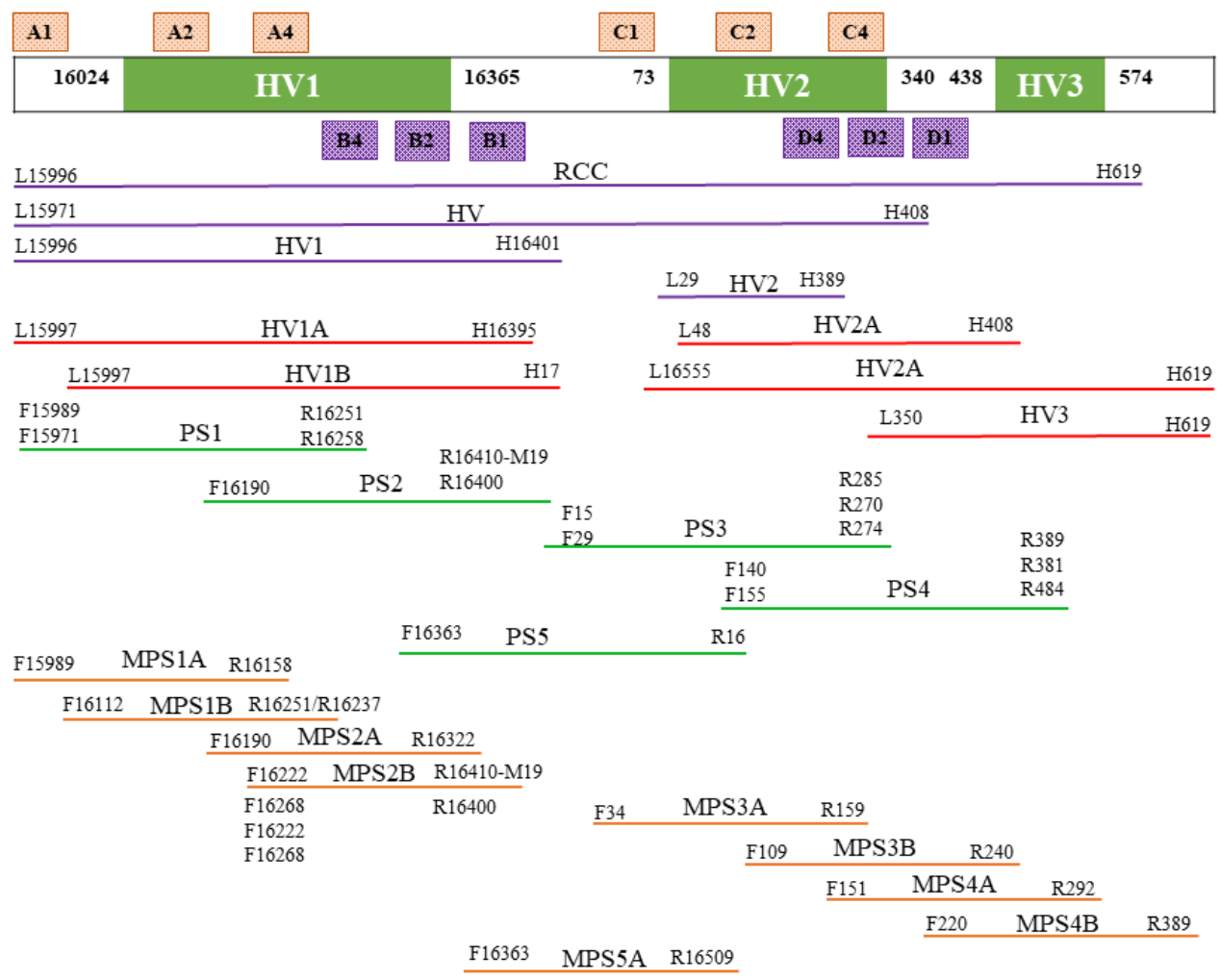

Figura 11. Mapa de los primers de amplificación de ADN mitocondrial 
En cualquier caso, la idea es amplificar la región HV con los primers adecuados, según el tipo de muestra o el estado de degradación en el que se encuentre. La amplificación se hará mediante PCR, Reacción en Cadena de Polimerasa, técnica enzimática que consiste en la producción de un gran número de copias de una región seleccionada del ADN (en función de los primers empleados) mediante ciclos de calentamiento y enfriamiento que van a dar lugar a tres fases diferentes: desnaturalización del $\mathrm{ADN}$, hibridación de los primers en sus respectivas secuencias complementarias, y elongación de la nueva cadena mediante la acción de la ADN polimerasa. La PCR tiene como ventajas la necesidad de pequeñas cantidades de ADN molde, permite trabajar con ADN degradado por necesitar moldes de únicamente unos pocos cientos de pares de bases, se pueden amplificar varias regiones a la vez en PCR multiplex, el ADN contaminante de hongos y bacterias no es problema por ser los primers específicos para ADN humano, y hay en el mercado una amplia variedad de kits comerciales que facilitan el trabajo de laboratorio. No obstante, también es cierto que puede no haber amplificación por la presencia de inhibidores de la PCR, que la hibridación del primer puede no ocurrir por variaciones en el genoma molde que lo impidan, y la susceptibilidad de contaminación de otro ADN de procedencia humana, que hace necesaria trabajar con las técnicas e instalaciones adecuadamente validadas (Butler, 2011).

La reacción de PCR se hará con un volumen final de $25 \mu 1$, con 2,5 $\mu 1$ de buffer, $1,5 \mu 1$ de cloruro de magnesio $\left(\mathrm{MgCl}_{2}\right) 25 \mathrm{mM}, 0,5 \mu \mathrm{l}$ de dNTPs (desoxinucleótido) 10mM, 0,5 $\mu \mathrm{lde}$ BSA (albúmina de suero bovino) y $0,5 \mu \mathrm{l}$ de Taq Polimerasa (2,5 U). El termociclador se configurará para un calentamiento inicial de $95^{\circ} \mathrm{C}$ durante un minuto (si la polimerasa es de tipo Hot Start, con el fin de que libere la molécula que la inactiva), para luego establecer 32 ciclos de $95^{\circ} \mathrm{C}$ x $10 \mathrm{~s}, 60^{\circ} \mathrm{C}$ x $30 \mathrm{~s}$, y $72^{\circ} \mathrm{C}$ x $30 \mathrm{~s}$. Una vez terminada la reacción, debe comprobarse el resultado en un gel de agarosa al $2 \%$ sumergido en TBE (Tris-Borato-EDTA), debiendo observarse si realmente se ha efectuado la amplificación del ADN mitocondrial.

\subsection{Purificación del producto de amplificación.}

Este paso diferencia el análisis de ADN mitocondrial del protocolo estándar de análisis de ADN nuclear, y su objetivo es la eliminación de los dNTPs y primers de la amplificación anterior, puesto que podrían interferir en la etapa analítica posterior. Las técnicas más empleadas son las columnas de QiaQuick y el ExoSAP-ITTM.

Las columnas de Qiagen, QIAquick PCR Purification Kit, emplean el clásico método de purificación de lavado-centrifugado-elución. Funcionan añadiendo 5 volúmenes de buffer PB al volumen de amplificado, trasladando el conjunto a una columna que se centrifuga durante 3060 segundos, añadiendo para lavar $750 \mu 1$ de buffer PE, se vuelve a centrifugar, se centrifuga una última vez un minuto para, finalmente, añadir $50 \mu \mathrm{l}$ del eluyente de buffer EB (que contiene Tris 
10mM), centrifugando una última vez (QIAGEN, 2018). Por su parte, ExoSAP-IT ${ }^{T M}$ es una técnica enzimática que hidroliza los primers y nucleótidos que no han intervenido en la reacción de PCR; pasa usarlo no hay más que añadir $2 \mu 1$ de reactivo a $5 \mu 1$ de producto de PCR, incubar a $37^{\circ} \mathrm{C}$ durante 15 minutos, incubar nuevamente otros 15 minutos a $80^{\circ} \mathrm{C}$ (para inactivar la enzima), y ya está listo para el siguiente paso (Appliedbiosystems, 2017).

Una comparativa de ambos métodos de purificación nos muestra que con las columnas de Qiagen se recupera un $75 \%$ del ADN, mientras que con ExoSAP-IT ${ }^{\mathrm{TM}}$ se recuperaba un $78 \%$ del mismo, siendo este último a su vez mucho menos laborioso de ejecutar al no requerir centrifugación, por lo que es al mismo tiempo más fácil para trabajar con un mayor número de muestras; los dos métodos proporcionan la misma calidad en los electroferogramas al secuenciar las muestras posteriormente a su purificación, dando ExoSAP-IT ${ }^{\mathrm{TM}}$ los mismos resultados ya se analicen las muestras a continuación o dos meses después (Dugan, Lawrence, Hares, Fisher, \& Budowle, 2002).

\subsection{Secuenciación del ADN mitocondrial.}

Ahora que ya tenemos nuestras múltiples copias del genoma mitocondrial, o de aquellas regiones concretas que nos interesa observar, necesitamos saber qué nucleótidos y en qué orden están dispuestos, es decir, la secuencia de bases nitrogenadas de nuestro fragmento de interés. Para ello hay distintos métodos, como viene siendo habitual, pero desde su desarrollo sin duda el más utilizado es la secuenciación de Sanger, la cual hemos tenido ocasión de ver más arriba, y que ahora veremos más en profundidad.

El centro del método de Sanger es el empleo de dideoxinucleótidos (ddNTPs), idénticos a los deoxinucleótidos (dNTPs) empleados en la amplificación, exceptuando la reducción del grupo -OH del carbono 3' de la desoxirribosa, lo que impide que la cadena de la que forma parte siga creciendo, teniendo por tanto propiedades terminadoras. De esta manera, si imaginamos nuestro tubo Eppendorf, y visualizamos nuestra cadena de ADN molde, inmersa en un medio en el que abundan deoxinucleótidos, dideoxinucleótidos, ADN polimerasa y un primer, veremos cómo se une en primer lugar el primer a la cadena molde, comenzando la ADN polimerasa la síntesis de la nueva cadena, a través de la unión complementaria y al azar de los distintos deoxinucleótidos, hasta que, de nuevo azarosamente, se une un dideoxinucleótido, que impide que la cadena siga creciendo, terminando la replicación. Este proceso se irá repitiendo constantemente, de manera que acabaremos teniendo la unión de únicamente el dideoxinucleótido correspondiente al primer nucleótido de nuestra secuencia de interés, el primer deoxinucleótido y el segundo terminador, y así sucesivamente, obteniendo finalmente, como se muestra en la figura 12, multitud de fragmentos de $1,2 \ldots$ nucleótidos. 
A diferencia de una reacción de PCR normal, la secuenciación utiliza únicamente un primer, lo que aumenta exponencialmente la cantidad de producto final obtenido. La clave está en que los dideoxinucleótidos están unidos a un marcador fluorescente, de manera que, si por electroforesis capilar separa toda nuestra variedad de fragmentos por tamaños, y a medida que avanzan se aplica un láser que lee el fluorocromo de los diferentes dideoxinucleótidos, tendremos al final del proceso la secuencia completa de nuestro fragmento de ADN mitocondrial de interés (Álvarez et al., 2001). De entre los kits disponibles en el mercado probablemente el más utilizado sea BigDye ${ }^{\circledR}$ Terminator v1.1 Cycle Sequencing Kit, de Applied Biosystems, una premezcla que contiene los reactivos necesarios para la secuenciación de Sanger, incluyendo un buffer de secuenciación BigDye ${ }^{\mathrm{TM}}$ Terminator v1.1 5X especialmente diseñado para la tarea. Para usarlo no hay más que mezclar $8 \mu \mathrm{l}$ de mix de reacción, 3,2 pmol del primer forward y reverse a 3,2 $\mu \mathrm{M}$, una cantidad de producto de PCR que variará en función del número de pares de bases del ADN molde (150-300 ng aproximadamente), y agua destilada en cantidad suficiente para llevar a $20 \mu \mathrm{l}$ de volumen final (Applied Biosystems, 2016).

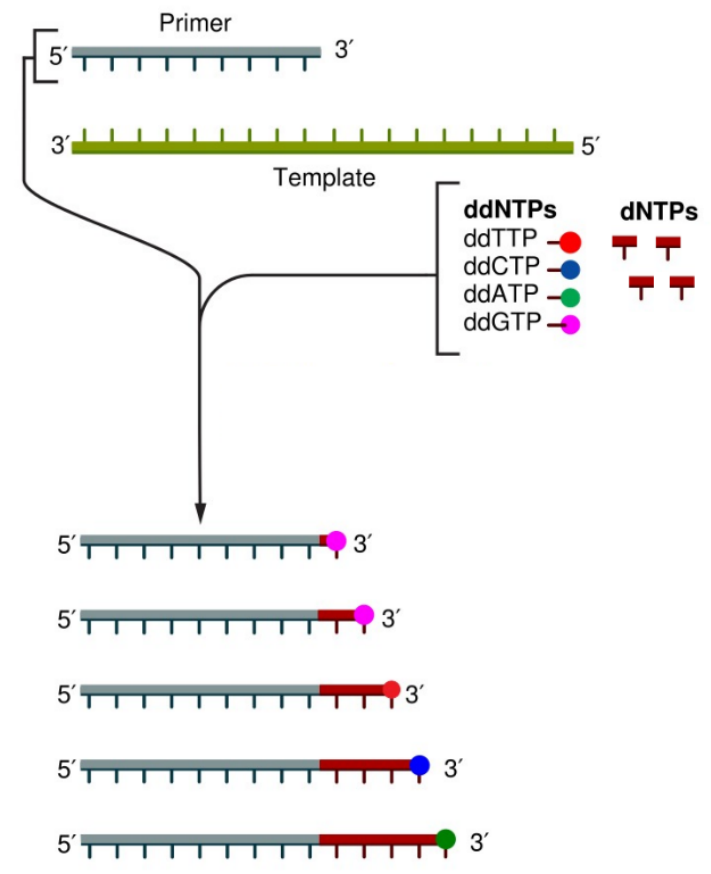

Figura 12. Esquema de la secuenciación de Sanger. Fuente: Wikipedia.

Posterior a la secuenciación es necesario realizar una purificación del producto de secuenciación para, nuevamente, eliminar los primers, deoxinucleótidos y dideoxinucleótidos sobrantes, pues podrían interferir en el análisis que se haga a continuación. Tradicionalmente se venía haciendo mediante precipitación con etanol y cloruro de magnesio, pero este proceso resultaba largo y laborioso si eran varias las muestras con las que se tenía que trabajar, resultando para estos casos especialmente útiles los kits de BigDye XTerminator ${ }^{\mathrm{TM}}$ y las columnas Performa ${ }^{\circledR}$ DTR. El kit de purificación BigDye XTerminator ${ }^{\text {TM }}$ consiste en añadir dos 
soluciones diferentes, una que elimina los terminadores que no se han incorporado (solución XTerminator), así como las sales, y otra que estabiliza el producto de la secuenciación y mejora la acción de la solución XTerminator (solución SAM), no teniendo más que añadir la mezcla de ambas soluciones a cada pocillo $(10 \mu 1$ de solución XTerminator y $45 \mu 1$ de solución SAM por pocillo), agitar durante 30 minutos y centrifugar brevemente (Applied Biosystems, 2006). Como alternativa tenemos las columnas de gel Performa ${ }^{\circledR}$ DTR de EdgeBio, columnas de $800 \mu \mathrm{l}$ contenidas en tubos de $1,5 \mathrm{ml}$ que eliminan los terminadores no incorporados, sales, buffers, primers y fragmentos de hasta 20 bases, empleando una matriz de gel hidratada sin conservantes, sales o tampones. Se usan de la siguiente manera: se centrifugan las columnas a $850 \mathrm{~g}$, se añade el producto de secuenciación, se vuelve a centrifugar 3 minutos a 850 g, y ya tenemos purificado el producto de secuenciación (EdgeBio, 2016).

Comparando ambas técnicas, se suele preferir el XTerminator a las columnas de gel por requerir mucho menos tiempo (Roby et al., 2014). Otro estudio las prefiere porque el trabajo es menos laborioso y se obtienen secuencias con menos artefactos cuando se purifica con XTerminator que con las columnas Centri-Sep empleadas en el estudio (Bourdon, Harris, Prinz, \& Shapiro, 2014). No obstante, se echa en falta algún estudio que compare ambas metodologías, o todas las disponibles en el mercado, a fin de establecer cuál es la que mejor visualización del electroferograma da, y así optimizar un poco más el análisis de ADN mitocondrial.

\subsection{Análisis e interpretación de los resultados.}

Como adelantamos, el último paso es la realización de una electroforesis capilar, que se hará en un analizador genético que incorpora un capilar relleno de polímero por el que van pasando las muestras que van separándose por tamaños; un rayo láser excita los fluorocromos (BigDye) unidos a los distintos dideoxinucleótidos, los cuales tienen distintos colores en función de la base nitrogenada (citosina en azul, adenina en verde, timina en rojo, o guanina en rosa) de la que se trate y la fluorescencia es captada por una cámara CCD (dispositivo de carga acoplada) que traduce la señal en forma de picos de fluorescencia. Son dos, por tanto, las variables a controlar, el Array y el polímero. Los Array vienen en distintas longitudes dependiendo de la aplicación que se le vaya a dar, siendo habitual ver los de $36 \mathrm{~cm}$ para identificación humana por STRs, mientras que en secuenciación se usan Arrays más largos, de unos $50 \mathrm{~cm}$, para que las muestras tengan más recorrido y los distintos fragmentos asociados a dideoxinucleótidos estén bien separados (esto, no obstante, es dependiente del tamaño del producto secuenciado). La otra variable a tener en cuenta es el polímero (o medio de separación), que nuevamente depende de la aplicación. POP-4 permite que las muestras vayan mucho más rápidas que en POP-6, cuya mayor densidad hace que vayan más lentas, siendo POP-7 intermedio entre ambos, y por ende, de los más utilizados (Gurson, 2016) 
Una vez terminado el experimento, un ordenador con un programa informático recoge las distintas intensidades de fluorocromo detectadas, elaborando un electroferograma como el que se ve en la figura 13. Podemos ver, en el eje de ordenadas, la intensidad de señal detectada en cada fluorocromo, y en las abscisas, las distintas bases nitrogenadas a las que se corresponden las mismas, obteniendo finalmente la secuencia en la que se encuentran los mismos en el individuo en cuestión.

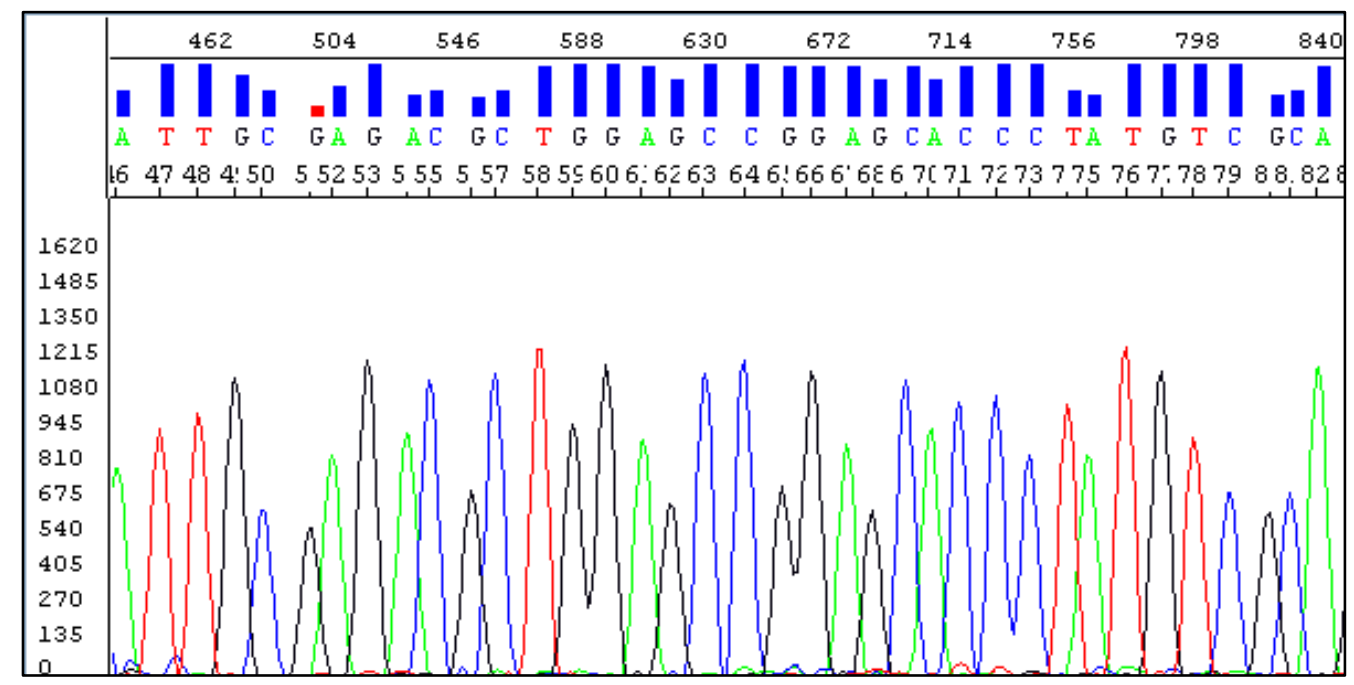

Figura 13. Electroferograma de secuenciación de ADN mitocondrial.

Lo que se hace es comparar el electroferograma del individuo analizado con la secuencia de referencia de Cambridge, anotando todos los polimorfismos que se observen. Por ejemplo, en la figura 14 podemos ver los electroferogramas de los primers forward y reverse en el software SeqScape, que nos señala un polimorfismo en la posición 16 207, que en la Secuencia de Referencia es una adenina, siendo una guanina en nuestro individuo. Anotamos este polimorfismo de sustitución como A16207G. En la tabla 5 pueden verse los distintos tipos de polimorfismos que nos podemos encontrar y su nomenclatura. 


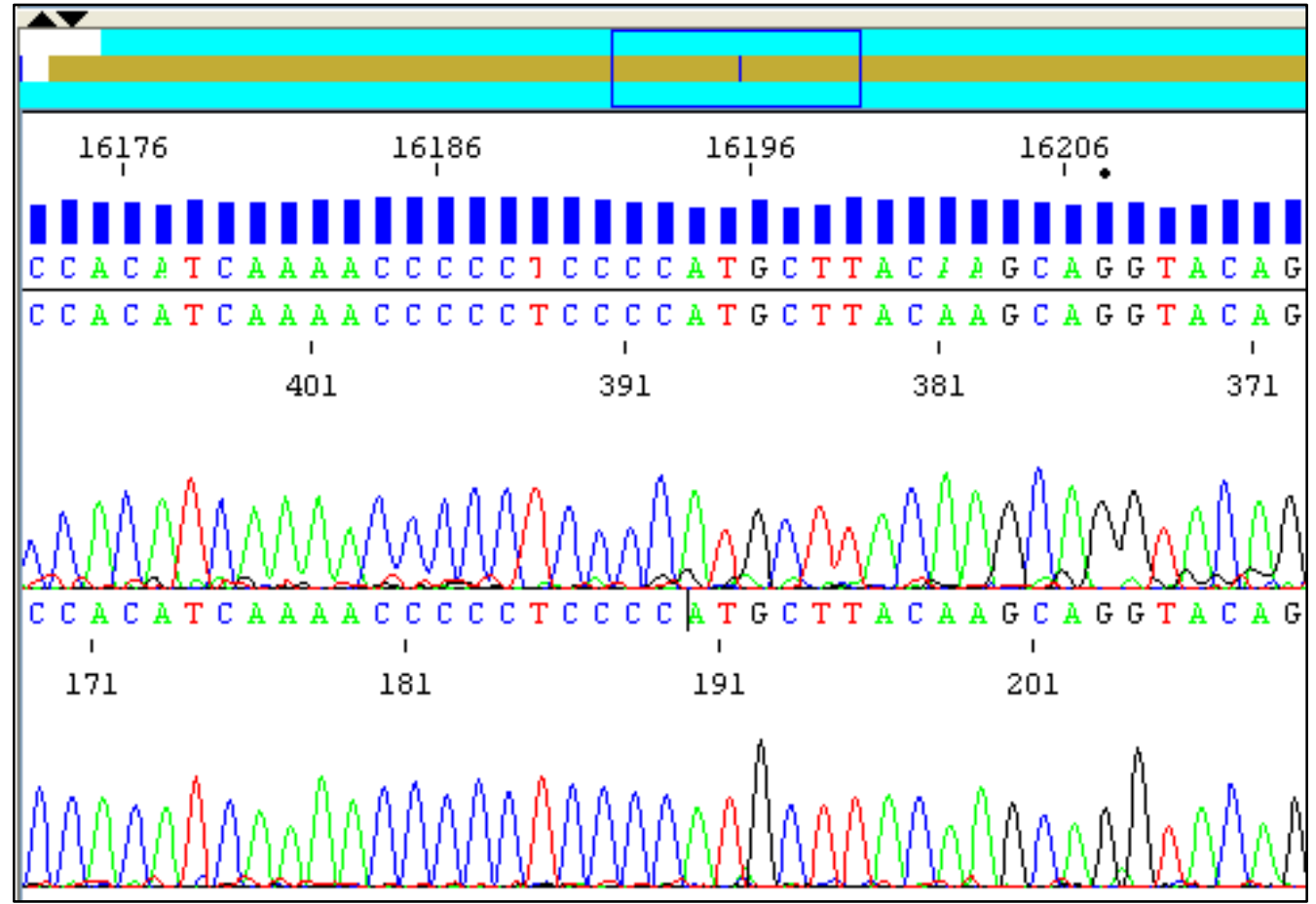

Figura 14. Comparación de las secuencias de los primers forward y reverse con la rCRS con SeqScape.

Tabla 5. Nomenclatura de los polimorfismos (W. Parson et al., 2014)

\begin{tabular}{|c|c|c|c|}
\hline Polimorfismo & Fenómeno & Nomenclatura & Ejemplo \\
\hline Sustitución & $\begin{array}{l}\text { Cambio de un } \\
\text { nucleótido por otro. }\end{array}$ & $\begin{array}{l}\text { Posición del nucleótido con el } \\
\text { correspondiente a la rCRS como } \\
\text { prefijo y el nuevo nucleótido como } \\
\text { sufijo. }\end{array}$ & $\mathrm{T} 152 \mathrm{C}$ \\
\hline Inserción & $\begin{array}{l}\text { Un nucleótido se } \\
\text { introduce en la } \\
\text { secuencia. }\end{array}$ & $\begin{array}{l}\text { Posición de la inserción, punto, } \\
\text { número de nucleótidos que se insertan, } \\
\text { nucleótido. }\end{array}$ & $309.2 \mathrm{C}$ \\
\hline Deleción & $\begin{array}{l}\text { Un nucleótido se ha } \\
\text { eliminado de la } \\
\text { secuencia. }\end{array}$ & $\begin{array}{l}\text { Posición de la deleción con "DEL", } \\
\text { "del" o "-" como prefijo. }\end{array}$ & DEL16240 \\
\hline Heteroplasmia & $\begin{array}{l}\text { Mezcla de dos } \\
\text { nucleótidos en una } \\
\text { misma posición. }\end{array}$ & $\begin{array}{l}\text { Posición en la que se observa seguida } \\
\text { de una letra según International Union } \\
\text { of Pure and Applied Chemistry } \\
\text { (IUPAC). } \\
\text { R (A/G), Y (C/T), S (G/C), W (A/T), } \\
\text { K (G/T), M (A/C), B (C/G/T), D } \\
(A / G / T), H(A / C / T), V(A / C / G), \\
\text { N (A/G/C/T). }\end{array}$ & $16110 R$ \\
\hline
\end{tabular}

Se considera una exclusión dos o más discrepancias entre las variaciones encontradas entre una muestra y otra con respecto a la rCRS. Por supuesto, los resultados deben proporcionarse con la incertidumbre inherente al cálculo estadístico realizado con los mismos. Ya vimos que una de las desventajas del análisis de ADN mitocondrial es su herencia en bloque, pudiendo considerarse el mismo como un único locus con una amplia variabilidad. El ADN mitocondrial 
tiene un índice de mutación mucho mayor que el ADN nuclear, lo que solventa un poco el problema, pero también favorece la aparición de heteroplasmias, que complican todavía más el asunto porque si la muestra está degradada puede no observarse. La clave está en las bases de datos de $\mathrm{ADN}$ mitocondrial, pues lo que se hace es proporcionar la frecuencia de las distintas variaciones anotadas en una base de datos de tamaño $\mathrm{N}$; como vimos, existen bases de datos de ADN mitocondrial en las que diferentes investigadores suben los polimorfismos que observan, calculándose la frecuencia observada de los mismos. Es así como la probabilidad de coincidencia $\left(\mathrm{M}_{\mathrm{x}}\right)$ será como en la tabla 6

Tabla 6. Probabilidad de coincidencia y probabilidad de coincidencia al azar (Balding \& Steele, 2015)

\begin{tabular}{|c|l|}
\hline$M_{x}=F_{S T}+p\left(1-F_{S T}\right)$ & $\begin{array}{l}M_{x}=\text { Probabilidad de coincidencia. } \\
F_{S T}=\text { Frecuencia del haplotipo en la población. } \\
p=\text { Probabilidad de coincidencia al arar. }\end{array}$ \\
\hline $\mathbf{p}=\frac{\mathrm{x}+2}{\mathbf{N}+2}$ & $\begin{array}{l}\mathbf{x}=\text { Frecuencia del haplotipo en la base de datos. } \\
\mathbf{N}=\text { Tamaño de la base de datos. }\end{array}$ \\
\hline
\end{tabular}

Las fórmulas se aplican a poblaciones en las que los diferentes grupos están mezclados, no teniendo en cuenta individuos relacionados por vía materna, si bien es cierto que las investigaciones dejan de lado el estudio de regiones concretas de las frecuencias de los distintos haplotipos en la población. En el caso de coincidencia con un perfil que presente heteroplasmia no es necesario modificar las fórmulas, excepto que $\mathrm{p}$ va a referirse a la proporción de individuos en la población que presentan la misma heteroplasmia; si la secuencia dubitada e indubitada se diferencian únicamente en que una presenta heteroplasmia y la otra no, no se podrá hacer una exclusión; lo mismo que si presentan los mismos polimorfismos, pero una presenta heteroplasmia y la otra no; y si se diferencian únicamente en un nucleótido, el resultado será inconcluyente. Por supuesto, lo que finalmente haremos es el cálculo de la razón de verosimilitud, likelihood ratio o $\mathbf{L R}$, que no es más que el cociente de la probabilidad de dos hipótesis: que la muestra dubitada proceda del individuo indubitado, o que sea de un individuo aleatorio de la población (Buckleton, Triggs, \& Walsh, 2005)

Merece la pena que nos paremos brevemente a ver cómo trata el Poder Judicial la prueba pericial de ADN, a la que el ADN mitocondrial tiene cada vez más que aportar, y es que la prueba pericial de ADN es el medio de identificación que más ha avanzado en las últimas décadas y que con más frecuencia se emplea en el ámbito jurídico (Fernández Villazala \& García Borrego, 2016). La Sentencia del Tribunal Supremo de 24 de febrero de 1995 establece el grado de probabilidad mínimo exigido para las pruebas de ADN, remitiéndose a la jurisprudencia europea y a especialistas en la materia, abogando por un 99,73\% (el caso alemán) o un 99,8 \% (el caso suizo). No obstante, un resultado positivo de identificación únicamente vincula a una persona con 
un objeto o escenario, necesitando de un juicio lógico inductivo sólidamente construido para vincular a la persona al hecho delictivo; si la prueba de ADN es la única existente y es factible proponer alternativas plausibles, se debe decantar uno por la solución absolutoria, como recoge la Sentencia del Tribunal Supremo 949/2006, de 4 de octubre de 2006.

En esta vía merece la pena aclarar, para cerrar ya este apartado de valoración estadística de los resultados, las falacias a las que pueden inducir estos datos a los distintos operadores jurídicos (Thompson \& Schumann, 1987), lo que en España ha venido a denominarse la falacia del fiscal y la falacia de la defensa (Carracedo \& Prieto, 2014). La falacia del fiscal consiste en explicar los resultados de ADN como la probabilidad de que el crimen lo haya cometido esa persona en concreto, mientras que la falacia de la defensa entiende que, si hay tal probabilidad de encontrar un individuo en la población con ese mismo genotipo, habrán podido ser tantas personas de esa ciudad o región. Ambas son falsas, el valor de LR no es más que una medida de la incertidumbre del resultado, cuestión que debería imponerse en todas las disciplinas criminalísticas, y que no expresa otra cosa que sea tantas veces más probable explicar los resultados como identificación positiva que como coincidencia con un individuo no relacionado escogido al azar de la población.

\section{La secuenciación de nueva generación (NGS).}

La técnica de secuenciación de ADN de Sanger no solamente supuso el avance de la identificación mediante ADN mitocondrial, sino que también motivó el continuo avance o mejora de la técnica (ya hemos visto que el ADN forense avanza a hombros de gigantes), dando pie a lo que se viene conociendo como secuenciación de nueva generación (next generation sequencing, NGS). NGS no es más que el nombre que se le da a un conjunto de plataformas diferentes que trabajan en el marco de la tecnología de la secuenciación, y que tienen en común la secuenciación de millones de fragmentos de ADN en paralelo y el uso de técnicas de análisis de Bioinformática para poner esos fragmentos en relación y obtener, de esta manera, información del genoma individual completo, técnica que cada vez se emplea más habitualmente en el ámbito clínico (Behjati \& Tarpey, 2013). La técnica es básicamente la misma en todos los sistemas: se construye una librería formada por nuestro ADN de interés, el cual es fragmentado y marcado con un oligonucleótido que identifica cada fragmento, realizándose millones de copias de los mismos para, posteriormente, unirlos. La importancia de las plataformas NGS reside en la secuenciación masiva en paralelo (MPS), nada más y nada menos que la secuenciación de múltiples secuencias de ADN al mismo tiempo, lo que abre un prometedor campo para las Ciencias Forenses (Bruijns, Tiggelaar, \& Gardeniers, 2018).

La secuenciación de segunda generación vino de mano del sistema Roche 454, basado en la técnica de pirosecuenciación, que consiste en la detección, no de los dideoxinucleótidos 
marcados con fluorocromos, sino de la reacción de luminiscencia provocada por la unión de una molécula de ATP a la luciferina, sintetizada a partir de una molécula de pirofosfato generada cuando a la cadena sintetizada por la ADN polimerasa se une el nucleótido correcto, dando una capacidad de lectura de 500-1000 pares de bases. Como alternativa se lanzarían los sistemas Illumina, que beben de la secuenciación por síntesis, la cual consiste en la fijación de primers reversibles a un soporte sólido sobre los cuáles se realizarán las múltiples copias de ADN, registrándose el pico de fluorescencia de cada nucleótido que se une a cada fragmento; de esta manera los errores de la replicación son fácilmente detectables por detectarse el nucleótido erróneo muy pocas veces con respecto al correcto, siendo capaz de leer de 100 a 600 giga pares de bases. AB SOLiD 5500 e Ion PGM e IonProton se aprovechan también de la secuenciación por síntesis, empleando el primero PCR en emulsión de agua y aceite y DNA ligasa en lugar de polimerasa, y el segundo la detección de protones liberados durante la polimerización del ADN. La secuenciación de tercera generación, marcada por Helioscope y PacBio, se caracteriza por la tendencia a la secuenciación de una sola molécula (SMS, single molecule sequencing), de mínimo 25 pares de bases, pero a partir de la cual se pueden hacer lecturas de toda su secuencia, empleando Helioscope secuenciación por luminiscencia y PacBio detectores de la actividad ADN polimerasa. La secuenciación de cuarta generación, en desarrollo actualmente, emplea los sistemas Nanopore, que no son más que un nanoporo embebido en una solución salina al que al que se aplica una corriente eléctrica, detectándose la secuencia de la cadena de ADN por la forma que tengan los iones de atravesarla (Álvarez-Cubero et al., 2017). En la tabla 7 puede verse una comparativa de los distintos sistemas que acabamos de ver, y ya podrá el lector imaginar las enormes implicaciones que estas nuevas técnicas pueden tener para la Criminalística.

Tabla 7. Sistemas de secuenciación de nueva generación (Álvarez-Cubero et al., 2017).

\begin{tabular}{|c|c|c|c|c|c|c|c|}
\hline & Empresa & Tecnología & Lectura & Salida & Tiempo & Error & $\begin{array}{l}\text { ADN } \\
\text { mínimo }\end{array}$ \\
\hline $\begin{array}{l}454 \mathrm{GS} \\
\text { FLX+ }\end{array}$ & Roche & $\begin{array}{c}\text { Piro- } \\
\text { secuenciación }\end{array}$ & $1000 \mathrm{pb}$ & $\begin{array}{l}700 \\
\mathrm{Mb}\end{array}$ & $23 \mathrm{~h}$ & $0,003 \%$ & $500 \mathrm{ng}$ \\
\hline HiSeq 2500 & Illumina & Síntesis & $\begin{array}{c}2 \times 100 \\
\mathrm{pb}\end{array}$ & $\begin{array}{l}600 \\
\mathrm{~Gb}\end{array}$ & 11 días & $<0,01 \%$ & $\begin{array}{c}1 \mu g-50 \\
n g\end{array}$ \\
\hline MiSeq & Illumina & Síntesis & $\begin{array}{c}2 \times 300 \\
\mathrm{pb}\end{array}$ & $15 \mathrm{~Gb}$ & $4-65 h$ & $<0,01 \%$ & $\begin{array}{l}1 \mu \mathrm{g}- \\
50 \mathrm{ng}\end{array}$ \\
\hline SOLiD 5500 & Life Tech. & Ligación & $75 \mathrm{pb}$ & $90 \mathrm{~Gb}$ & 7 días & $0,001 \%$ & $1-3 \mu \mathrm{g}$ \\
\hline $\begin{array}{c}\text { Ion Torrent } \\
\text { PGM }\end{array}$ & Life Tech. & $\begin{array}{l}\text { Semi- } \\
\text { conductor/ } \\
\text { síntesis }\end{array}$ & $\begin{array}{c}35-400 \\
\text { pb }\end{array}$ & $2 \mathrm{~Gb}$ & $2-7 \mathrm{~h}$ & $<1 \%$ & $10 \mathrm{ng}$ \\
\hline Helioscope & $\begin{array}{c}\text { Helicos } \\
\text { Biosciences }\end{array}$ & SMS & $35 \mathrm{pb}$ & $27 \mathrm{~Gb}$ & 8 días & $\begin{array}{c}2-7 \% \\
0,2-1 \%\end{array}$ & $<2 \mu \mathrm{g}$ \\
\hline $\begin{array}{c}\text { PacBio RS } \\
\text { II } \\
\end{array}$ & $\begin{array}{c}\text { Pacific } \\
\text { Biosciences }\end{array}$ & SMS & $\begin{array}{c}30000 \\
\mathrm{pb}\end{array}$ & $\begin{array}{l}230 \\
\mathrm{Mb}\end{array}$ & $\begin{array}{c}30-180 \\
\min \end{array}$ & $<0,001 \%$ & $2-10 \mathrm{ng}$ \\
\hline $\begin{array}{l}\text { GridION } \\
\text { Nanopore }\end{array}$ & $\begin{array}{c}\text { Oxford } \\
\text { Nanopore }\end{array}$ & $\begin{array}{c}\text { SMS/ } \\
\text { Nanopore }\end{array}$ & $>2 \mathrm{~kb}$ & - & $6 \mathrm{~h}$ & $2 \%$ & - \\
\hline
\end{tabular}


En efecto, las implicaciones que puede tener la NGS en la Genética Forense son diversas, pues la idea de ser capaz de secuenciar cada molécula de ADN de una muestra es casi un sueño para el experto, permitiendo indagar algo más en el problema de la muerte súbita, o aumentar la finura de las investigaciones sobre suelos que diferencian los mismos estudiando los microorganismos que los habitan, y, por supuesto, para los estudios de ADN (Børsting \& Morling, 2015). Las ventajas de la NGS para el análisis de ADN son diversas: tanto en análisis de STRs autosómicos como del cromosoma Y permitiría una detección de mezclas más sencilla, al tiempo que facilita el cálculo de la proporción de la misma, permitiendo además el análisis de SNPs autosómicos, que proporcionarían una enorme cantidad de información de linajes, ancestría y marcadores fenotípicos, facilitando a su vez el análisis del ADN mitocondrial (Álvarez-Cubero et al., 2017). El análisis de ADN mitocondrial mediante NGS puede ser especialmente útil tanto por el interés forense como del no forense del genoma mitocondrial: las cada vez mayores aplicaciones de la NGS abaratan los equipos y reactivos, la secuenciación paralela permite trabajar simultáneamente con muchas muestras, lo que reduce nuevamente los costes, presenta una gran sensibilidad para la detección de heteroplasmias, lo que mejoraría la discriminación, y las mezclas de perfiles se distinguirían fácilmente en caso de que se produjeran (Y. Yang, Xie, \& Yan, 2014). A este respecto, se encuentra actualmente en desarrollo el kit ForenSeq ${ }^{\mathrm{TM}}$ mtDNA de Verogen, nutrido de los últimos conocimientos en secuenciación de ADN mitocondrial para desarrollar los amplicones, promete integrar la Bioinformática para secuenciar, tanto la región control como el genoma completo, en menos de dos días de trabajo (Verogen, 2019)

No obstante, la NGS sigue proyectándose como perteneciente a un futuro no muy lejano, por motivos diversos: la ausencia de correlación entre la secuencia obtenida del análisis de STRs con las variaciones en longitud, con las que se trabaja actualmente, no se tiene tanta experiencia en la interpretación de los resultados y de los posibles errores de los mismos como en electroforesis capilar, que lleva décadas de técnica e investigación detrás; la protección de datos, pues la posibilidad de secuenciar todo el ADN de un individuo choca con la tendencia actual de la protección de datos en materia de datos genéticos de uso forense, que impera que el mismo sea no codificante y que no aporte información fenotípica o de patologías del individuo, lo que lleva también a la ausencia de una base de datos genéticos obtenidos por NGS. Es por ello que primero es necesario una nomenclatura uniforme relacionada con los STRs, establecer un mínimo de lecturas, recoger las recomendaciones pertinentes para los errores de lectura, determinar qué estrategias de NGS se ajustan mejor a cada caso, disponer cómo se almacenan los resultados, con qué software, y qué interpretaciones estadísticas pueden hacerse de los mismos (de Knijff, 2019).

Muy recientemente para el momento de escribir estas líneas, el Scientific Working Group on DNA Analysis Methods (SWGDAM) ha validado el análisis forense de STRs autosómicos mediante NGS (Scientific Working Group on DNA Analysis Methods, 2019a). También se ha 
modificado la guía de interpretación de ADN mitocondrial para incluir las NGS (Scientific Working Group on DNA Analysis Methods, 2019b). De hecho, hace unos días tuvo lugar en Países Bajos la primera sentencia condenatoria con pruebas de ADN obtenidas mediante NGS (Tabak, 2019), lo que sin duda abre las puertas al futuro del análisis forense del ADN.

\section{Los grupos de trabajo sobre análisis de ADN mitocondrial.}

Una de las piedras angulares del progreso científico es la dinámica colaborativa establecida en la creación de grupos de trabajo en los que se compartan experiencias, errores, y se elaboren protocolos normalizados y buenas prácticas conjuntas, lo que favorece el intercambio de resultados y el seguimiento de metodologías estandarizadas, así como el control de la actividad científica. En este sentido vamos a pararnos un poco en los grupos de trabajo de ADN de la International Society for Forensic Genetics (ISFG), aunque no podemos más que recomendar la observación de los protocolos generales emitidos por la European Network of Forensic Sciences Institutes (ENFSI), el Grupo Iberoamericano de Trabajo con ADN (GITAD), y la Comisión Nacional para el Uso Forense del ADN (CNUFADN).

La ISFG, con más de 1200 miembros de más de 60 países diferentes, fue fundada en 1965 en Mainz, Alemania, por un grupo de científicos interesados en el estudio forense del tejido sanguíneo, deslizándose al estudio forense del ADN desde el descubrimiento de este uso del mismo. La asociación ha resultado ser un eje central a la hora de aglutinar el conocimiento científico sobre estudio forense del ADN, organizando grupos de trabajo, congresos internacionales, y publicaciones de referencia en la materia. Entre estas recomendaciones figura una guía para el estudio del ADN mitocondrial (W. Parson et al., 2014):

1) Seguir las buenas prácticas de laboratorio y los protocolos específicos de trabajo con ADN mitocondrial.

2) Realizar blancos de extracción, controles negativos y controles positivos durante todos los procesos del laboratorio.

3) Las secuencias que se reporten deben estar basadas en información repetida, secuenciando en forward y reverse siempre que se pueda.

4) Se debe evitar transcribir los datos a mano, debiendo confirmarse el haplotipo por dos científicos diferentes.

5) Los laboratorios, especialmente los que se dediquen a estudios forenses, deben someterse a exámenes de control de sus procedimientos.

6) En estudios poblacionales para bases de datos forenses se debe secuenciar la región control completa.

7) Las secuencias de $\mathrm{ADN}$ mitocondrial se deben alinear y reportar con respecto a la rCRS e incluir el rango de interpretación. 
8) Los puntos de heteroplasmia deben indicarse siguiendo la nomenclatura de la IUPAC.

9) La alineación y notación de las secuencias de ADN mitocondrial debe seguir criterios filogenéticos, empleando para ello las herramientas disponibles en EMPOP.

10) En estudios forenses, los laboratorios deben elaborar sus propias guías de interpretación de heteroplasmias, dependiendo la evaluación de las mismas de las posibilidades del laboratorio.

11) Para muestras de estudios poblacionales, las heteroplasmias de longitud en secuencias homopoliméricas deben interpretarse con la variedad dominante de las mismas.

12) Las bases de datos de ADN mitocondrial deben someterse a software analítico que realice un control de calidad de las mismas.

13) La base de datos de secuencias disponibles debe ser también registrada para evitar resultados sesgados.

14) Los laboratorios deben poder justificar la elección de las bases de datos y las aproximaciones estadísticas en sus informes.

15) Los laboratorios deben establecer guías de interpretación estadística a la hora de identificar dos muestras.

16) Las posiciones altamente variables deben evitarse a la hora de hacer estimaciones de frecuencia.

\section{La cuantificación de ADN como herramienta de optimización del análisis de ADN.}

Si el lector ha llegado hasta aquí, habrá pensado que la diversidad de métodos y técnicas de análisis de ADN mitocondrial hace ciertamente complejo la obtención de un resultado, esto es, el tan ansiado perfil genético de la muestra ósea antigua. Teniendo en cuenta que la muestra constituye el primer paso, y de las características de la misma van a depender todos los pasos siguientes, sería muy interesante disponer de alguna técnica que nos informe del estado del resto óseo, es decir, cuánto ADN contiene y en qué estado de degradación. Es aquí donde se inserta la cuantificación de ADN como una herramienta para optimizar el análisis de ADN mitocondrial en restos óseos antiguos.

El objetivo de la cuantificación de ADN es determinar la cantidad aproximada de ADN presente en una muestra extraída, con el objetivo de determinar cuánto se amplificará posteriormente en la PCR, pues la misma tiene un rango óptimo de cantidad a amplificar (entre 0,5 y 2 ng habitualmente), de manera que, si la cantidad a amplificar introducida es demasiado baja, no podrán apreciarse en la visualización de resultados los picos de fluorescencia, con lo que perderíamos información, o bien si la cantidad es demasiado alta podrían observarse artefactos como pull-ups (un pico tiene una intensidad tal que el aparato detecta un falso pico en otro fluorocromo) o picos -A (dobles picos causados por errores de síntesis de la Taq polimerasa, usualmente la adición de una adenina de más), traduciéndose todo ello en problemas de 
interpretación y en tiempo y trabajo (Butler, 2014). Como viene siendo habitual, disponemos de diferentes técnicas de cuantificación de ADN (Butler, 2011):

a) Absorbancia en ultravioleta y cuantificación en gel. Los primeros métodos de cuantificación de ADN se basaban en la medida de la absorbancia de la muestra a $260 \mathrm{~nm}$ o en la fluorescencia emitida por las muestras en geles con bromuro de etidio. Estos métodos tienen la desventaja de que consuman una cantidad de muestra que puede ser muy valiosa, y que no son muy sensibles, además de no ser específicos para ADN humano.

b) Slot blot. Constituía el método más usado en los laboratorios forenses de los años 90 hasta principios de los 2000 para ADN nuclear, siendo una técnica específica para ADN humano por una sonda que se unía a una secuencia del cromosoma 17. El ADN se captura en una membrana de nylon a la que se añade la sonda específica para humanos, y unos reactivos provocan una reacción quimioluminiscente o colorimétrica cuya intensidad de señal se compara con la dada por unos patrones de concentración conocida. Por no ser muy sensible, consumir mucha muestra, y llevar mucho tiempo, y no ser realmente tan específico para humanos, dejó de usarse en 2006.

c) PicoGreen. La búsqueda de métodos automatizados de cuantificación de ADN desembocó en que en los años 90 el Servicio de Ciencias Forenses del Reino Unido desarrollara un método basado en PicoGreen (un fluorocromo intercalado) capaz de detectar desde $250 \mathrm{pg}$ de ADN en una placa de 96 pocillos. La única pega es que no es específico para humanos.

d) Sistemas AluQuant. Desarrollado por Promega, cuantifica el ADN aprovechando las secuencias Alu, de unos 300 pares de bases, muy abundantes en el ADN humano. La hibridación de una sonda inicia una serie de reacciones enzimáticas que oxidan luciferina, produciendo una luz cuya intensidad se mide con un luminómetro, dando una sensibilidad de 0,1 a 50 ng de ADN.

e) PCR de punto final. Como solución menos elegante al problema de la cuantificación, se puede amplificar una región concreta del ADN (normalmente el marcador de la amelogenina) con muestras de concentración conocida, generando una curva que se compara con la muestra problema, a partir de la señal generada por un fluorocromo; método poco elegante pero funcional, habida cuenta de que nos informa también de la presencia de inhibidores de la PCR.

\subsection{PCR a tiempo real (rt-PCR).}

Merece su propia sección el que probablemente sea el método más usado actualmente de cuantificación de ADN, la PCR a tiempo real (real time PCR) o PCR cuantitativa (quantiative PCR), cuya piedra angular son las sondas TaqMan, curiosamente llamadas así por el microorganismo Thermus aquaticus y el personaje del videojuego Pac-Man, dado que sus creadores se dieron cuenta de la similitud entre la actividad de la sonda con la mecánica del 
videojuego (P. M. Holland, Abramson, Watson, \& Gelfand, 1991). Las sondas TaqMan están marcadas con dos fluróforos diferentes que emiten luz a distinta longitud de onda (tabla 8), hibridando las mismas en las regiones de interés entre los dos primers a una temperatura superior a la de estos, con la intención de que precisamente hibriden cuando comience la polimerización; a veces se unen moléculas MGB (Minor Groove Binder, unión al surco menor) al extremo 3’ de la sonda para poder usar secuencias más cortas con temperaturas de hibridación mayores que las esperadas para secuencias de la misma longitud. Como decíamos, son dos fluróforos: el indicador ( $\mathrm{R}$, de reporter), unido al extremo 5', y el inhibidor, ( $\mathrm{Q}$, de quencher), sintetizado en el extremo 3', siendo las combinaciones más frecuentes los fluorocromos FAM o VIC para indicador y TAMRA para el inhibidor. Cuando la sonda está libre el indicador está muy cerca del supresor, no observándose fluorescencia; es en la polimerización cuando la actividad 5'-exonucleasa de la Taq polimerasa libera la molécula indicadora, que, al no estar cerca de la supresora, emite fluorescencia (véase la figura 15), de forma que únicamente se obtendrá fluorescencia con la síntesis de secuencias complementarias a la sonda TaqMan. Es por tanto fundamental que la sonda pueda hibridar con el ADN que pretendemos cuantificar, por ello algunos ensayos como el kit de Quantifiler incluyen un control interno de PCR (IPC, Internal PCR Control) que permite verificar que la polimerasa, el ensayo y el detector funcionan correctamente al estar el IPC marcado con VIC e hibridar con un molde sintético mientras que la sonda TaqMan para la región de interés está etiquetada con FAM (azul), diferenciables espectralmente (Butler, 2011).

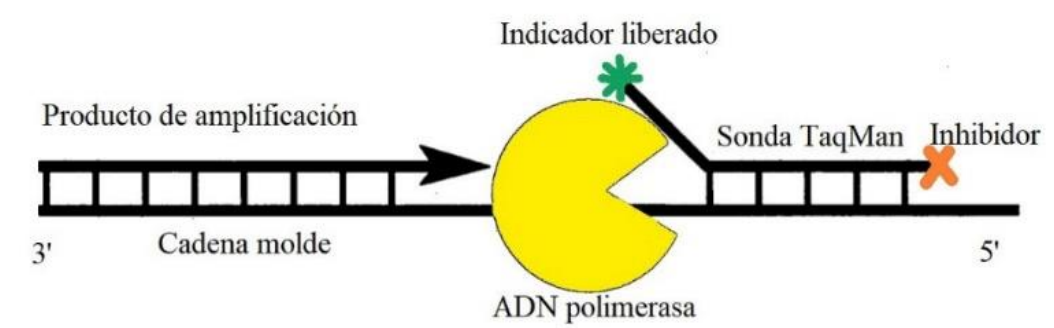

Figura 15. Diagrama de sondas TaqMan (P. M. Holland et al., 1991). 
Tabla 8. Fluróforos y sus inhibidores recomendados (BioCat, s. f.)

\begin{tabular}{|c|c|c|c|c|c|c|}
\hline \multirow[t]{2}{*}{ Color } & \multirow[t]{2}{*}{ Fluoróforo } & \multirow{2}{*}{$\begin{array}{l}\text { Marcador } \\
\text { alternativo }\end{array}$} & \multicolumn{2}{|c|}{$\begin{array}{c}\text { DYE-5' - } \\
\text { T }\end{array}$} & \multirow{2}{*}{$\begin{array}{l}\text { Inhibidor } \\
\text { recomendado }\end{array}$} & \multirow[t]{2}{*}{ Color } \\
\hline & & & EX & EM & & \\
\hline & $\begin{array}{c}\text { Biosearch } \\
\text { Blue }^{\mathrm{TM}}\end{array}$ & - & 352 & 447 & BHQ-1 & \multirow[t]{4}{*}{ Dine cossen } \\
\hline & FAM & - & 495 & 520 & BHQ-1 & \\
\hline & TET & - & 521 & 536 & BHQ-1 & \\
\hline & $\begin{array}{l}\text { CAL Fluor }{ }^{\circledR} \\
\text { Gold } 540\end{array}$ & VIC/TET/JOE & 522 & 544 & BHQ-1 & \\
\hline & JOE & - & 529 & 555 & BHQ-1 & \multirow{3}{*}{$\begin{array}{l}\text { BHQ-1 } \\
400.500 \mathrm{~nm}\end{array}$} \\
\hline & VIC & - & 538 & 554 & - & \\
\hline & HEX & - & 535 & 556 & BHQ-1 & \\
\hline & $\begin{array}{l}\text { CAL Fluor } \\
\text { Orange } 560\end{array}$ & VIC/HEX/JOE & 538 & 559 & BHQ-1 & \multirow{5}{*}{$\begin{array}{l}\text { BHQ-2 } \\
559-670 \mathrm{~nm}\end{array}$} \\
\hline & Quasar® ${ }^{\circledR} 570$ & CY3 & 548 & 566 & BHQ-2 & \\
\hline & $\mathrm{ABY}{ }^{\circledR}$ & - & - & 580 & - & \\
\hline & $\mathrm{Cy}^{\mathrm{TM}} 3.5$ & - & 581 & 596 & - & \\
\hline & ROX & - & 586 & 610 & BHQ-2 & \\
\hline & $\begin{array}{l}\text { CAL Fluor } \\
\text { Red } 610\end{array}$ & $\begin{array}{l}\text { TEXAS RED/ } \\
\text { ROX/ ALEXA } \\
\text { FLUOR® } 594\end{array}$ & 590 & 610 & BHQ-2 & \\
\hline & JUN® & - & - & 617 & - & \\
\hline & Pulsar ® 650 & - & 460 & 650 & BHQ-2 & \\
\hline & Cy 5 & & 646 & 669 & - & \\
\hline & Quasar 670 & CY5 & 647 & 670 & BHQ-2, BHQ-3 & \\
\hline & Су 5.5 & & 675 & 694 & - & \multirow[b]{2}{*}{ 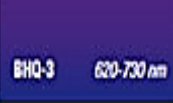 } \\
\hline & Quasar 705 & CY5.5 & 690 & 705 & BHQ-2, BHQ-3 & \\
\hline
\end{tabular}

Todo proceso de PCR está definido por tres fases, las cuales pueden apreciarse en un gráfico de fluorescencia frente a número de ciclos de PCR (Butler, 2011), como se aprecia en la

\section{figura 16:}

1) Fase de amplificación geométrica o exponencial. Hay un alto grado de producción de duplicados de ADN hasta que se llega al $100 \%$ de eficiencia en la reacción, momento en el cual se duplican los amplicones con cada ciclo. Un gráfico de número de ciclos frente al logaritmo de la concentración de ADN mostraría aquí una relación lineal.

2) Fase lineal. Después de la fase exponencial, uno o más de los componentes de la PCR cae a una concentración crítica y el ritmo de la amplificación cae a una relación aritmética. Como los componentes de la PCR como los dNTPs o los primers se usan a concentraciones ligeramente diferentes entre reacciones, la fase lineal no coincide entre las muestras.

3) Fase de meseta. La fase final de la PCR, en la que la obtención de producto de amplificación se ralentiza debido al fin de la efectividad de los componentes que intervienen, cesando la amplificación. 

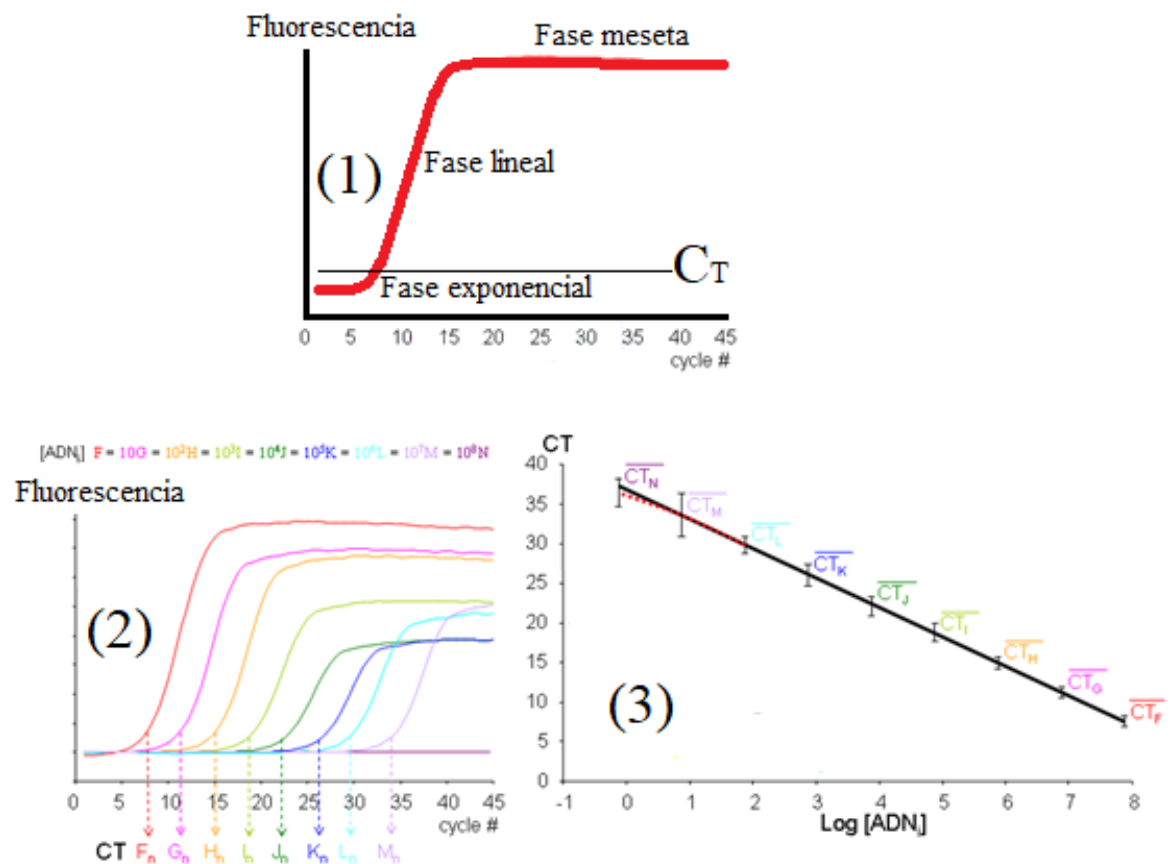

Figura 16. Representación gráfica de un ensayo de rt-PCR. En (1) se observan las diferentes fases de un ensayo de PCR en un gráfico de número de ciclos frente a fluorescencia. En (2) se pueden ver las gráficas correspondientes a diluciones seriadas de una muestra dada, obteniéndose en (3) la recta de regresión correspondiente al logaritmo de la concentración de $\mathrm{ADN}$ frente a $\mathrm{C}_{\mathrm{T}}$, lo que permite conocer la concentración de ADN de una muestra problema.

Es la fase exponencial la ideal para medir la fluorescencia según el número de ciclos por ser más consistente la relación entre cantidad de producto de amplificación y ADN introducido. El cálculo se hace con lo que se ha venido a denominar ciclo umbral (cycle threshold, $\mathbf{C}_{\mathbf{T}}$ ), cuyo valor se corresponde con el punto en términos de ciclos de amplificación en el que el nivel de fluorescencia excede un límite arbitrario establecido por el software de análisis de la rt-PCR para que esté por encima del nivel observado de ruido y al mismo tiempo cerca de las primeras fases de la PCR, de manera que cuanto menos ciclos lleve poder detectar fluorescencia, mayor será el número de copias de $\mathrm{ADN}$ inicial, de manera que gráficamente observaremos una relación negativa entre el logaritmo de la concentración de $\mathrm{ADN}$ frente al valor de $\mathrm{C}_{\mathrm{T}}$ (Butler, 2011), en lo que ha venido a denominarse método de $\Delta \mathbf{C}_{\mathbf{T}}$.

Todo lo dicho es, por supuesto, un modelo teórico e ideal, pues en un verdadero ensayo de PCR intervienen diversos procesos estocásticos, motivados quizás por la baja concentración inicial de ADN molde o que en cada ciclo no todas las enzimas sinteticen nuevo ADN. Es por ello que los resultados más fiables van a obtenerse atendiendo a la fase exponencial, de donde nace el método de $\Delta \mathrm{C}_{\mathrm{T}}$, pero si seguimos el razonamiento anterior, podemos concluir que asumir que todos los ciclos tienen la misma eficiencia es erróneo, por lo que son necesarios métodos que tengan en cuenta estos factores para obtener un valor más exacto de la cantidad de ADN de nuestra muestra problema. Eso es precisamente lo que hace el método de $\Delta \mathrm{C}_{\mathrm{T}}$ antes visto: de diluciones 
seriadas hace una recta de regresión que permita identificar posteriormente la cantidad de ADN de una muestra problema. El otro método disponible se basa igualmente en la linealización de una función logarítmica, contemplando en esta ocasión el rendimiento de cada ciclo de PCR calculado con la expresión $\log N c=\log N o+c \cdot \log E$, siendo Nc la cantidad de ADN obtenida, No la cantidad de ADN inicial, c el número de ciclos y E la eficiencia de la reacción, método automatizado en diversos programas informáticos y que parece dar buenos resultados (Karlen, McNair, Perseguers, Mazza, \& Mermod, 2007).

Por supuesto, la técnica de la rt-PCR no está exenta de problemas. El más importante es el de todos los métodos de PCR y que esbozábamos más arriba: la presencia de inhibidores, que pueden afectar a la actividad de la ADN polimerasa, y por ende mostrarnos un falso negativo. No obstante, la limitación más frecuente va a ser la humana: desarrollo incorrecto del experimento, análisis de los datos inadecuado, conclusiones sin los debidos intervalos de confianza, amén de requerir un diseño de primers cuidadoso y validado (Valasek \& Repa, 2005)

\subsection{Cuantificación de ADN mitocondrial por rt-PCR.}

Los primeros estudios de cuantificación de ADN mitocondrial estaban destinados al conteo de moléculas de ADN mitocondrial en muestras óseas para estudio de ADN antiguo mediante PCR competitiva, en las que se usan diluciones de un ADN molde competidor de concentración conocida se amplificaba con una cantidad constante de extracto, calculándose la ratio de competidor amplificado con respecto al extraído mediante la visualización de los resultados en electroforesis en gel con bromuro de etidio. Este método presentaba limitaciones muy aparentes, como la subjetividad de la medición, la escasa sensibilidad, y el consumo de la valiosa muestra (Alonso et al., 2003). La utilidad de la cuantificación del ADN nuclear posterior a la extracción y previa a la amplificación fue vista como de enorme utilidad, pues permitía comprobar si el mismo debía diluirse o concentrarse para que la amplificación fuera óptima, tanto es así que fue incluida como operación de rutina en el manual de calidad de análisis de ADN del FBI norteamericano (Federal Bureau Investigation, 2011), habitualmente haciendo la prueba con una sonda que hibrida con D17Z1. Esto es lo que se conoce como monoplex PCR, en la que se amplifica un único fragmento de ADN, sin embargo, ya se había visto la posibilidad de amplificar varios fragmentos de ADN al mismo tiempo, en lo que se denominó multiplex PCR, en la que se amplifican varios fragmentos de ADN al mismo tiempo; esto dio pie a que se pudieran cuantificar, al mismo tiempo, ADN nuclear y mitocondrial, con el fin de disponer rápidamente de una vía analítica alternativa en caso de que el primero fallase (Andréasson, Gyllensten, \& Allen, 2002).

En esta senda se observó que los ensayos de PCR multiplex permitían, no sólo obtener de un plumazo la información relativa a la cantidad de ADN nuclear y mitocondrial presente, sino 
que al mismo tiempo, si se amplificaban un fragmento largo (de unas 300 pares de bases) y uno corto (de unas 120 pares de bases) de ADN mitocondrial, se podía obtener una idea del estado de degradación del mismo, pues si asumimos que el ADN mitocondrial se fragmenta de manera aleatoria durante los distintos procesos degradativos a los que está sometido, el nivel de degradación va a ser inversamente proporcional al tamaño de los fragmentos que podamos amplificar (Alonso et al., 2003). En otras palabras, si tenemos información de cuánto ADN hemos extraído y cuán degradado está, podemos: primero, emplear otro método de extracción que sea más costoso o laborioso, pero que nos permita obtener más cantidad de ADN, y segundo, definir la estrategia de amplificación con fragmentos pequeños solapantes, en función del grado de degradación del ADN.

La última vuelta de tuerca la constituyen los ensayos de qPCR triplex de ADN mitocondrial, en los que en un solo experimento puede obtenerse la cantidad de ADN mitocondrial presente, el estado de degradación del mismo, y la presencia o ausencia de inhibidores de la PCR observando la amplificación de las muestras con respecto a los controles internos, lo que abriría una nueva vía analítica de, si se observa este fenómeno, la necesidad de repurificar la muestra o diluirla para mitigar los efectos de los inhibidores (Kavlick, 2019). Más fino todavía hilan los ensayos de qPCR quadruplex, en los que al mismo tiempo se mide la cantidad de ADN humano, ADN humano de varón, degradación del ADN y la presencia de inhibidores de la PCR; todos estos ensayos que pueden aumentar enormemente la eficiencia del trabajo de laboratorio y disminuir el riesgo de contaminación y el uso de la tan preciada y escasa muestra (Hudlow, Chong, Swango, Timken, \& Buoncristiani, 2008).

Las heteroplasmias, fenómeno relativamente frecuente en las muestras forenses, y relativamente más frecuentes en muestras de pelo, también son susceptibles de ser estudiadas mediante rt-PCR, permitiendo calcular el grado de heteroplasmia presente en una muestra dada, o incluso predecir el grado de heteroplasmia de un tipo de muestra a partir de otra, encontrándose que hay una relación fuerte entre el grado de heteroplasmia de los cabellos y de las células bucales de un mismo donante (Gallimore, McElhoe, \& Holland, 2018)

Finalmente, el problema de la interpretación estadística y con ella la obtención de valores los más exactos posible de la cantidad inicial de $\mathrm{ADN}$ mediante el método de $\Delta \mathrm{C}_{\mathrm{T}} \mathrm{se}$ complica con el análisis de ADN mitocondrial, en el que los fragmentos analizados no tienen todos el mismo tamaño, lo que hace necesario optimizar la expresión de $\Delta \mathrm{C}_{\mathrm{T}}$. A este respecto resulta especialmente interesante la expresión siguiente (Refinetti, Warren, Morgenthaler, \& Ekstrøm, 2017):

$$
\frac{N_{A}}{N_{B}}=2^{I_{A}-I_{B}}
$$


Donde $\mathrm{N}$ es el número de copias de un experimento, e I es la sensibilidad de la PCR a tiempo real, mayor cuanto menor sea el valor de $\mathrm{C}_{\mathrm{T}}$, y A y B se corresponden dos experimentos diferentes. Este método llega a ser muy atractivo si tenemos en cuenta de que da resultados exactos pese a que la eficiencia del experimento A y el experimento B sea distinta, y al mismo tiempo elimina la necesidad de hacer diluciones seriadas de una muestra patrón para obtener $\Delta \mathrm{C}_{\mathrm{T}}$.

\section{Objetivos y metodología del Trabajo Fin de Máster.}

El presente Trabajo Fin de Máster tiene el objetivo de diseñar un ensayo optimizar el análisis de ADN mitocondrial mediante la realización de una cuantificación por PCR a tiempo real que permita obtener información, tanto de la cantidad de ADN mitocondrial presente en el extracto, como del estado de degradación del mismo, lo que permitiría seleccionar con mejor criterio las técnicas a realizar con la finalidad de obtener un resultado.

Para ello se va a abordar una metodología experimental, teniendo como hipótesis nula que las muestras de ADN mitocondrial degradadas no muestran diferencias en su secuenciación que las no degradadas, describiéndose en el siguiente epígrafe los detalles del experimento. 


\section{Material y métodos.}

\section{Muestras de ADN.}

Para este tipo de estudios las muestras de ADN proceden de ADN genómico humano de líneas celulares (Alonso et al., 2004; Kavlick, 2019); muestras forenses o de interés forense como pelos, sangre, huesos o dientes (Alonso et al., 2004; Gallimore et al., 2018; Kavlick, 2019; Niederstätter et al., 2007; Swango, Timken, Chong, \& Buoncristiani, 2006); amplicones de muestras de secuencia conocida (Alonso et al., 2004), o muestras quirúrgicas (Refinetti et al., 2017), si bien la mayoría de estudios trabajan con ADN genómico humano precuantificado de diferentes casas comerciales(Alonso et al., 2004; Andréasson et al., 2002; Fregel, Almeida, Betancor, Suárez, \& Pestano, 2011; Hudlow et al., 2008; Swango et al., 2006; Timken, Swango, Orrego, \& Buoncristiani, 2005), si bien es cierto que algunos señalan que el ADN precuantificado comercial puede arrojar resultados cuantitativos mayores de los que cabría esperar con muestras forenses debido al excelente estado en el que las casas comerciales lo proporcionan (Phillips, Sprouse, \& Roby, 2014).

En nuestro estudio proponemos trabajar con diluciones seriadas (original, 1:10, 1:100 y 1:1000) de las siguientes muestras de $\mathrm{ADN}$ :

- K562 DNA High Molecular Weight 10 ng/ $\mu 1$ (Promega, Madison, WI). Purificado de línea celular de leucemia mieloide crónica humana a $10 \mathrm{ng} / \mu \mathrm{l}$.

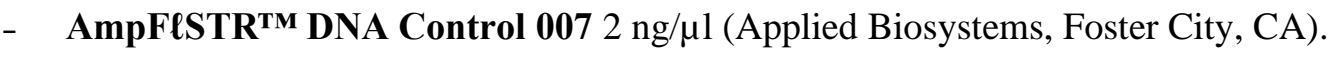

- Hisopado bucal. Muestra de mujer mediterránea, extraída con proteinasa K y fenol:cloroformo como protocolo de extracción.

\section{Degradación del ADN.}

Los estudios de degradación de ADN se pueden dividir entre los que trabajan con muestras presumiblemente ya degradadas como restos óseos (Alonso et al., 2004; Kavlick, 2019), pelos (Gallimore et al., 2018), o lo que se ha venido a denominar touch DNA o ADN de huellas latentes (Andréasson et al., 2002). El otro grupo lo conforman estudios con muestras .degradadas artificialmente con nucleasas (Hudlow et al., 2008; Niederstätter et al., 2007; Swango et al., 2006; Timken et al., 2005), siguiendo todos el mismo procedimiento, que será el elegido por este estudio. Hay uno que presenta una variación, y es que usó dos muestras a diferentes concentraciones, encontrando que la más diluida era la menos susceptible a la acción de degradación, lo que se corresponde con el fenómeno descrito por la Ecuación de MichaelisMenten, expresión de cinética química en la que la concentración del complejo enzima-sustrato 
es proporcional a la concentración de la enzima y del sustrato sin unir (Kavlick, 2019). Alternativamente, puede diluirse también la concentración de las DNasas (Hudlow et al., 2008).

El ensayo de degradación de ADN se realiza con DNase I (Invitrogen, Carlsbad, CA, USA), sometiendo las distintas diluciones de las muestras a la acción de la DNasa durante 0, 2,5, 5, 10, 20, 25, 40, 60, 90, 180 minutos y overnight. En un Eppendorf se añadirá $1 \mu 1$ de muestra o dilución y Buffer 10X DNase y agua destilada esterilizada en cantidad suficiente para completar $10 \mu 1$. Finalmente, salvo a las muestras de 0 minutos, se añadirá $2,5 \mu 1$ de DNase I a $1 \mathrm{U} / \mu 1$, dejándola actuar en los intervalos de tiempo antes mencionados, para pasado ese tiempo frenar su actividad con $2 \mu \mathrm{l}$ de EDTA a $25 \mathrm{mM}$ y dejando las muestras $15 \mathrm{~min}$ a $63{ }^{\circ} \mathrm{C}$ en agitación. Se comprobará la degradación de las muestras y las distintas diluciones con un gel de agarosa al 2\% con GelRed ${ }^{\circledR}$ Nucleic Acid Gel Stain (Biotium, Fremont, CA, USA) mezclando $4 \mu 1$ de muestra y $3 \mu$ de Stop Mix.

\section{Sondas y primers.}

Es menester preguntarnos qué región del ADN mitocondrial vamos a amplificar, punto en el que los experimentos de los diferentes estudios varían más, abarcando tanto regiones codificantes como ND1 (Gallimore et al., 2018; Timken et al., 2005), ND4 (Phillips et al., 2014), ND5 (Kavlick, 2019), RB1 (Niederstätter et al., 2007), 16S (Fregel et al., 2011), chrM (Refinetti et al., 2017), o tRNA lisina y ATP sintetasa 8 (Alonso et al., 2003); como regiones no codificantes, ya sean HV1 y HV2 (Phillips et al., 2014; Timken et al., 2005), HV1 (Alonso et al., 2004, 2003), o HV2 (Andréasson et al., 2002). Dado que el estudio es puramente cuantitativo nos convendría trabajar con una región del ADN mitocondrial cuya amplificación esté asegurada, por lo que más que las regiones hipervariables de interés forense amplificaremos la región 16S, gen de la subunidad $16 \mathrm{~S}$ del ADN ribosómico.

Los amplicones, por tanto, se han escogido para la región del ADN mitocondrial $16 \mathrm{~S}$ ((Fregel et al., 2011), véase la región turquesa de la figura 3), de 1559 pares de bases, localizado entre las bases 1671 y 3226 (Anderson et al., 1981) cuyas bases están cotejadas en la base de datos de ADN mitocondrial mtDB (Ingman \& Gyllensten, 2006), para verificar que es una zona escasamente polimórfica, al tiempo que se ha alineado la zona correspondiente de la rCRS con primates, mamíferos, aves y peces para asegurar la especificidad humana. En la tabla 9 pueden verse las secuencias de los primers y las sondas, y en la figura $\mathbf{1 7}$ una representación de los mismos.

La elección de esta región del ADN mitocondrial no es baladí a nivel forense. El uso del citocromo B para la identificación de especies no humanas ya nos es conocido, pero desde hace unos años se está comprobando el potencial del estudio de otras regiones del ADN mitocondrial, como es el caso del gen 16S, que de ser amplificado en sus secuencias inter-específicas e intra- 
específicas se generarían fragmentos muy pequeños, lo que sería de enorme interés para muestras degradadas o mínimas (Corato et al., 2011), como es el caso del tráfico de especies, de ejemplares de taxidermia, u órganos como colmillos o cuernos, permitiendo discriminar entre especies de mamíferos, aves, reptiles, e incluso primates entre sí y con respecto al humano (L. Yang et al., 2014).

Tabla 9. Primers y sondas utilizados en el experimento (Fregel et al., 2011).

\begin{tabular}{|c|c|c|}
\hline Fragmento & Primer/Sonda & Secuencia \\
\hline \multirow{2}{*}{$16 S$} & L2025 & 5'-GCC TGG TGA TAG CTG GTT GTC C-3' \\
\hline & H3018 & 5’-TCG TAC AGG GAG GAA TTT GAA-3' \\
\hline \multirow{3}{*}{$\begin{array}{c}\text { Fragmento } \\
\text { Corto } \\
(167 \text { pb) }\end{array}$} & Sonda & 5'-NED-AAT TTA ACT GTT AGT CCA AAG AG-3' \\
\hline & L2257 & 5'-GGT GAT AGC TGG TTG TCC AAG AT-3' \\
\hline & $\mathrm{H} 2543$ & $\begin{array}{l}\text { 5'-CCT ACT ATG GGT GTT AAA TTT TTT ACT CTC } \\
\text { TC-3' }\end{array}$ \\
\hline \multirow{3}{*}{$\begin{array}{c}\text { Fragmento } \\
\text { largo } \\
(314 \text { pb })\end{array}$} & Sonda & 5'-VIC-TCG GCA AAT CTT ACC CC-3' \\
\hline & L2030 & 5'-AAT CCC AAA CAT ATA ACT GAA CTC CTC-3' \\
\hline & H2174 & 5'-GCG GTG CCT CTA ATA CTG GTG-3' \\
\hline \multirow{3}{*}{$\begin{array}{c}\text { Fragmento } \\
\text { Interespecies } \\
(187 \mathrm{pb})\end{array}$} & Sonda & 5'-FAM-GGT TCG TTT GTT CAA CG-3' \\
\hline & L2928 & 5'-TTG ACC AAC GGA ACA AGT TAC C-3' \\
\hline & H3093 & 5'-GAC CTG GAT TAC TCC GGT CTG A-3' \\
\hline
\end{tabular}

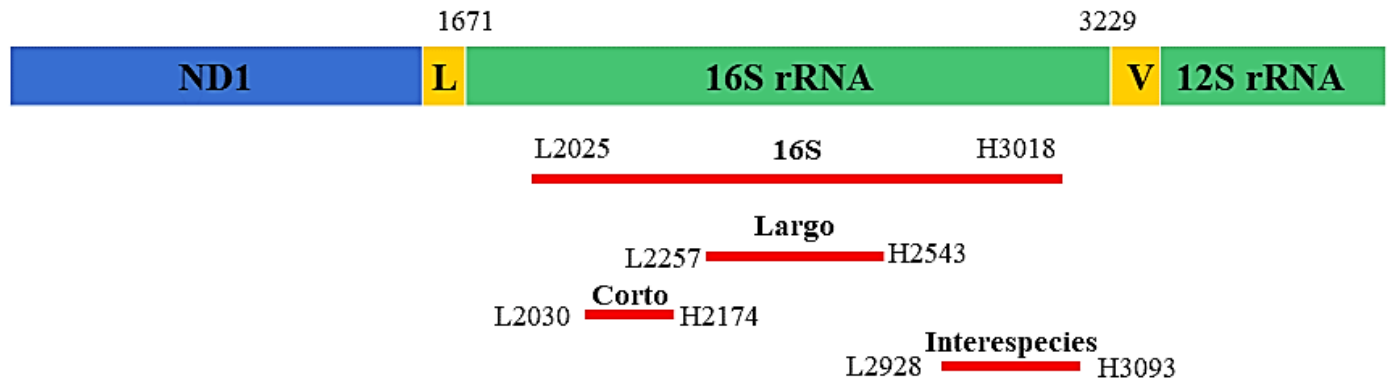

Figura 17. Primers para amplificación de 16S rRNA.

\section{Ensayo de rt-PCR.}

El ensayo de rt-PCR se optimizará para un equipo Applied Biosystems 7500 Real-Time PCR system (Applied Biosystems, Foster City, CA, USA), con un volumen final de $20 \mu \mathrm{l}$ al que se añaden $10 \mu 1$ de TaqMan Universal Master Mix (Applied Biosystems, Foster City, CA, USA), $1 \mu \mathrm{l}$ del set de primers $(0,5 \mu \mathrm{l}$ de cada primera $10 \mu \mathrm{M}), 0,5 \mu 1$ de AmpliTaq Gold®, 0,32 $\mu 1 \mathrm{de}$ BSA, y $2 \mu \mathrm{l}$ de muestra degradada diluida a 1:240 (Fregel et al., 2011). Las condiciones de la PCR se establecerán en $10 \min 95^{\circ} \mathrm{C}, 45$ ciclos de $15 \mathrm{~s} \mathrm{a} 95^{\circ} \mathrm{C}$, y $60 \mathrm{~s} \mathrm{a} 60^{\circ} \mathrm{C}$.

\section{Resultados esperados.}

Lo que se espera del diseño experimental propuesto es:

1) Comprobar la relación entre el tiempo y la acción de la DNasa.

2) Estudiar la relación entre concentración de la muestra y acción de la DNasa. 
3) Ver si hay diferencias en la degradación de la DNasa entre los dos controles y la muestra de interés forense.

Todo ello para poner en relación estas variables con la cantidad y calidad de ADN mitocondrial obtenidas mediante cuantificación por rt-PCR para, finalmente, poder optimizar el análisis de ADNmt mediante la cuantificación del extracto de ADN como se muestra en la figura 18, mediante la realización de otra extracción de otra muestra o la aplicación de otro protocolo de extracción si la cantidad de ADN es demasiado baja, o bien seleccionando distintas estrategias de amplificación en función de los fragmentos que hayan podido cuantificarse.

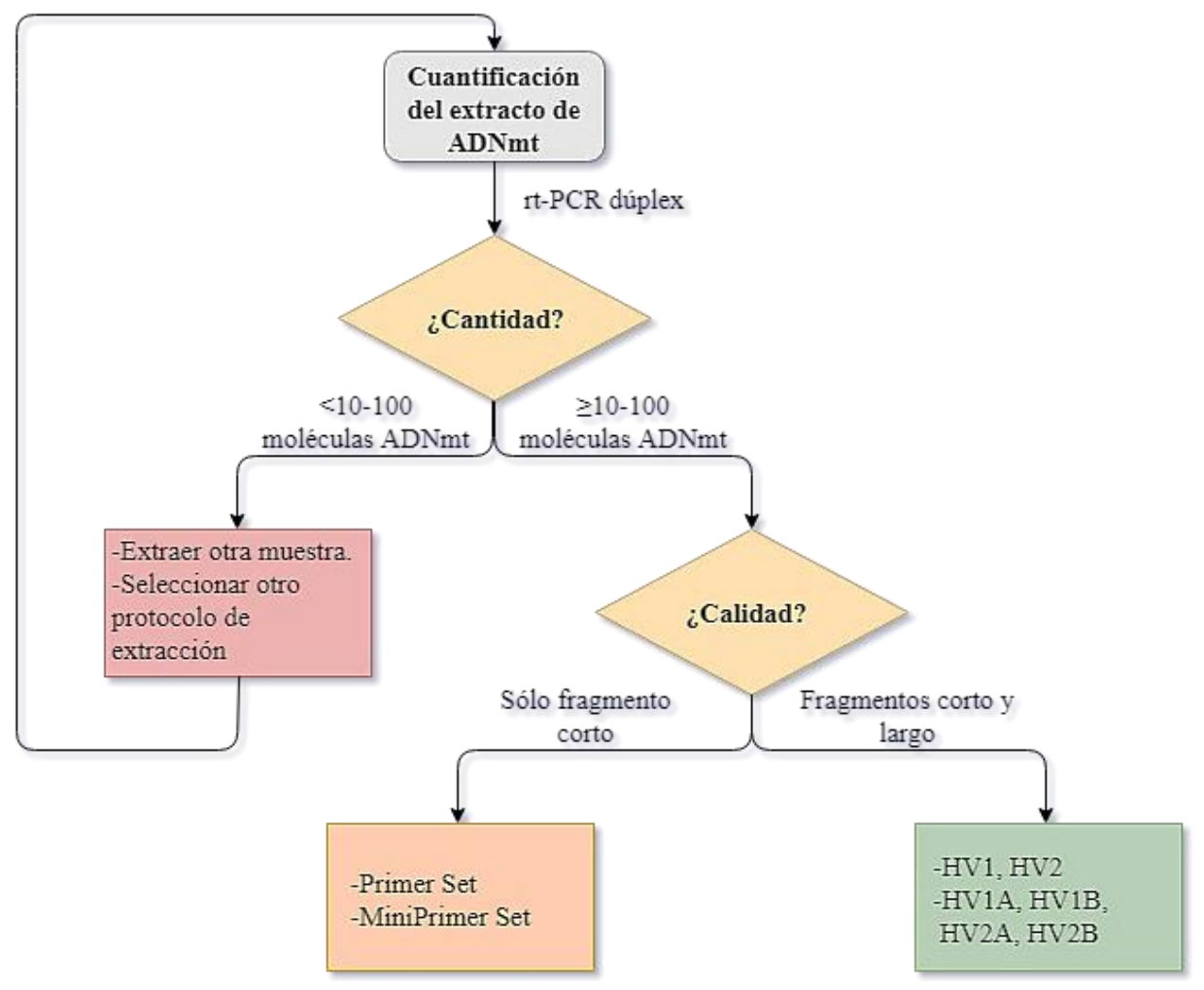

Figura 18. Optimización del análisis de ADN mitocondrial mediante cuantificación 


\section{Discusión y Conclusiones.}

El descubrimiento en 1985 del uso del ADN en la investigación criminal probablemente sea uno de los mayores avances de la Historia de la Criminalística desde el hallazgo a finales del siglo XIX de las huellas dactilares y su uso en la identificación humana, pues conseguía resolver por fin el problema de relacionar una muestra dubitada, como puede ser un indicio biológico hallado en la escena del crimen, con una muestra indubitada, tomada del sospechoso o de la víctima del proceso criminal. Las técnicas y las investigaciones se fueron depurando en poco tiempo, llegando hasta el estudio actual de STRs, que permiten identificar personas o sus relaciones sanguíneas con un altísimo grado de probabilidad (por supuesto, según el caso) y el estudio de SNPs, de cada vez mayor aplicación, unidos ambos a los prometedores avances en secuenciación de nueva generación.

Por supuesto, frente a la imagen planteada por los medios de comunicación, novelas, y series, el ADN ni es omnipotente ni todo poderoso, pues como el propio Jeffreys observó al poco tiempo de su descubrimiento, la técnica funciona muy bien con muestras frescas o recientes, pero no tanto con las antiguas y/o degradadas. Y es que el ADN está sometido a procesos naturales de degradación una vez se produce la muerte del individuo, a los que se une la acción de factores como el pH, la exposición a luz ultravioleta, la acción de microorganismos o de determinadas sustancias, factores todos ellos que actúan sobre el ADN impidiendo su conservación y alterándolo, impidiendo la obtención de un resultado.

En estas circunstancias se inserta el descubrimiento del ADN mitocondrial, cuyo mayor número de copias por célula permite obtener resultados precisamente en esas muestras problemáticas. El ADN mitocondrial, pequeño, circular, y con varias copias por mitocondria (y varias mitocondrias por célula), de herencia exclusivamente materna, y con una elevada tasa de mutación, pudiendo presentar incluso heteroplasmias (mutaciones en las propias mitocondrias del individuo que se traducen en la observación en una misma muestra del mismo individuo de más de un haplotipo) puede llegar a resultar enormemente útil en el análisis de muestras mínimas o muy degradadas, como pelos sin bulbo, hallazgo muy frecuente en la escena del crimen, o restos óseos, presentes en muchos escenarios (como conflictos armados, atentados terroristas, filiacioones, etc.); en estudios poblacionales humanos, pues es posible clasificar los distintos grupos humanos por su haplotipo, pudiendo además establecer relaciones entre ellos; y en análisis de $\mathrm{ADN}$ no humano, pues determinadas regiones del ADN mitocondrial nos permiten determinar la especie, animal o vegetal, de la que procede la muestra problema. 
La cuestión se complica teniendo en cuenta la amplia cantidad de variables a las que están sometidas las muestras: temperatura, humedad, $\mathrm{pH}$, composición del suelo, exposición a la luz solar son algunas de ellas. La selección de la propia muestra es también problemática: los restos óseos son, salvo excepciones, el tejido que más y mejor perdura en el tiempo, por lo que no es de extrañar que sean el centro de atención a la hora de hablar de identificación por ADN mitocondrial. Sin embargo, se ha visto que se obtienen más resultados con unos huesos que con otros, siendo los huesos largos más eficientes que los planos, y de entre todos ellos, las piezas dentales, si están intactas. La otra variable a tener en cuenta es el propio análisis del ADN, en un proceso que va desde la preparación de la muestra a la extracción del ADN mitocondrial, su amplificación, la purificación del producto de amplificación, la secuenciación, la purificación de la secuenciación y el análisis de los resultados. La multitud de técnicas existentes para cada procedimiento hacen necesarias la obtención de un procedimiento optimizado en función de la calidad de las muestras, y a su vez toda la operación analítica debe seguir las recomendaciones para trabajar con ADN antiguo, así como las emitidas por asociaciones científicas como la ISFG. A todo ello hay que sumar los continuos avances técnicos inherentes a la Genética Forense, estando actualmente en desarrollo kits de secuenciación de nueva generación de ADN mitocondrial.

Ante el abanico de técnicas disponibles, decíamos, se hace necesaria una optimización del análisis, para lo que resulta especialmente interesante la cuantificación de ADN. El objetivo es determinar la cantidad de $\mathrm{ADN}$ presente en un extracto, práctica habitual en los laboratorios (tanto es así que es uno de los principios de calidad del FBI), recordemos que la amplificación mediante PCR requiere la cantidad justa para obtener un perfil. Son diversas las técnicas de cuantificación de ADN, pero sin duda la reina es la PCR a tiempo real, rt-PCR, que, si bien tiene como desventaja la posible presencia de inhibidores de la PCR en la muestra, constituye una herramienta utilísima para la cuantificación de ADN, pues un solo ensayo permite determinar la cantidad de ADN humano en un extracto, la cantidad de ADN masculino, la cantidad de ADN mitocondrial, y la presencia de inhibidores de la ADN polimerasa. Con respecto al ADN mitocondrial, un único ensayo podría determinar cuánto $\mathrm{ADN}$ hay presente, y el estado de degradación del mismo, amplificando para ello dos fragmentos, uno corto y uno largo.

Surge así el objetivo del presente Trabajo Fin de Máster: diseñar un ensayo de cuantificación para optimizar el análisis de ADN mitocondrial (ver figura 18). Para ello vamos a degradar artificialmente unas muestras de ADN genómico humano precuantificado mediante la acción de nucleasas (DNasa I), dejándolas actuar durante distintos intervalos de tiempo, frenando su acción con EDTA y calor. Posteriormente, se amplificarán dos fragmentos, uno corto y uno largo, del gen 16S rRNA del genoma mitocondrial, pues al ser una región codificante nos aseguramos de que la amplificación no se produzca por la no hibridación del primer, pero al 
mismo tiempo constituye una región de interés forense al permitir su análisis determinar la especie de la que procede la muestra en caso de que se determine que se trata de ADN no humano. Estos dos fragmentos, de 167 y 314 pares de bases, nos van a informar de dos aspectos: primero, la cantidad de ADN mitocondrial inicial, y segundo, la calidad del mismo, según amplifiquen los dos fragmentos, únicamente el corto, o ninguno.

De esta manera, en un estudio de ADN mitocondrial, si podemos saber cuánto ADN hemos conseguido extraer, podremos establecer si tomamos otra muestra que pueda ser más prometedora (por ejemplo, otra pieza ósea mejor conservada), o bien, si aplicamos otro método de extracción, con el objetivo de conseguir más cantidad de ADN con la que poder trabajar. Y si podemos averiguar el grado de degradación que presenta la muestra, podremos establecer la estrategia de amplificación que mejor se ajuste al estado de la misma. Es así como la ejecución de una única técnica permite el ahorro de costes materiales y de tiempo al análisis de ADN mitocondrial, para finalmente aspirar al tan ansiado resultado: la obtención de un perfil genético a partir de restos óseos antiguos.

En Byrgenwerth, el maestro Willem tuvo una epifanía. "Estamos pensando en los planes más viles. Lo que necesitamos es más ojos" (Miyazaki, 2015). 


\section{Bibliografía.}

Ageno, M., Dore, E., \& Frontali, C. (1969). The alkaline denaturation of DNA. Biophysical Journal, 9(11), 1281-1311.

Allentoft, M. E., Collins, M., Harker, D., Haile, J., Oskam, C. L., Hale, M. L., ... Bunce, M. (2012). The half-life of DNA in bone: measuring decay kinetics in 158 dates fossils. Proceedings of the Royal Society B Biological Sciences, 279(1748), 4724-4733.

Alonso, A., Martín, P., Albarrán, C., García, P., García, Ó., Fernández de Simón, L., ... Fernández-Piqueras, J. (2004). Real-time PCR designs to estimate nuclear and mitochondrial DNA copy number in forensic and ancient DNA studies. Forensic Science International, 139, 141-149.

Alonso, A., Martín, P., Albarrán, C., García, P., Primorac, D., García, O., .. Fernández-Piqueras, J. (2003). Specific Quantification of Human Genomes from Low Copy Number DNA Samples in Forensic and Ancient DNA Studies. Croatian Medical Journal, 44(3), 273-280.

Álvarez-Cubero, M. J., Saíz, M., Martínez-García, B., Sayalero, S. M., Entrala, C., Lorente, J. A., \& Martínez-González, L. J. (2017). Next generation sequencing: an application in forensic sciences? Annals of Human Biology, 1464-5033 (Online).

Alvarez, A. J., Khanna, M., Toranzos, A., \& Stotzky, G. (1998). Amplification of DNA bound on clay minerals. Molecular Ecology, 7, 775-778.

Álvarez, J. C., Entrala, C., Lorente, J. A., Fernández-Rosado, F., Martínez-Espín, E., Rodríguez, E., \& Villanueva Cañadas, E. (2001). Análisis de ADN mitocondrial. Forénsica, 1(1), 4059.

Anderson, S., Bankier, A. T., Barrel, B. G., de Bruijn, M. H. L., Coulson, A. R., Drouin, J., ... Young, I. G. (1981). Sequence and organization of the human mitochondrial genome. Nature, 290, 457-465.

Andréasson, H., Gyllensten, U., \& Allen, M. (2002). Real-Time DNA Quantification of Nuclear and Mitochondrial DNA in Forensic Analysis. BioTechniques, 33, 402-411.

Andrews, R. M., Kubacka, I., Chinnery, P. F., Lightowlers, R. N., Turnbull, D. M., \& Howell, N. (1999). Reanalysis and revision of the Cambridge reference sequence for human mitochondrial DNA. Nature Genetics, 23, 147.

Applied Biosystems. (2006). BigDye ${ }^{\circledR}$ XTerminator ${ }^{\mathrm{TM}}$ Purification Kit. Recuperado 4 de mayo 
de 2019, de https://www.thermofisher.com/document-connect/documentconnect.html?url=https\%3A\%2F\%2Fassets.thermofisher.com\%2FTFS-

Assets\%2FLSG\%2Fmanuals\%2Fcms_042775.pdf\&title=UHJvdG9jb2wgU3VtbWFyeTog QmlnRHIlJnJlZzsgWFRlcm1pbmF0b3ImdHJhZGU7IFB1cmlmaWNhdGlvbiBLaXQ=

Applied Biosystems. (2016). BigDye ${ }^{\mathrm{TM}}$ Terminator v1.1 Cycle Sequencing Kit. Recuperado 10 de mayo de 2019, de https://assets.thermofisher.com/TFSAssets/LSG/manuals/MAN0015667_BigDyeTerminator_V1_1_CycleSeq_QR.pdf

Appliedbiosystems. (2017). ExoSAP-IT ${ }^{\mathrm{TM}}$ PCR Product Cleanup. Recuperado 4 de mayo de 2019, de https://www.thermofisher.com/document-connect/documentconnect.html?url=https\%3A\%2F\%2Fassets.thermofisher.com\%2FTFS-

Assets\%2FLSG\%2Fmanuals\%2F78200b.pdf\&title=QnJpZWYgUHJvdG9jb2w6IEV4b1N BUC1JVCBQQ1IgUHJvZHVjdCBDbGVhbnVwIEJyaWVmIFByb3RvY29s

Balding, D. J., \& Steele, C. D. (2015). Weight-of-Evidence for Forensic DNA Profiles (2 ${ }^{\mathrm{a}}$ Edición). London: Wiley.

Barrio-Caballero, P. A. (2012). Revisión de métodos de extracción de ADN a partir de restos óseos en el laboratorio forense. Revista Española de Medicina Legal, 39(2), 54-62.

Behar, D. M., van Oven, M., Rosset, S., Kivisild, T., Torroni, A., \& Villems, R. (2012). A «Copernican» Reassessment of the Human Mitochondrial DNA Tree from its Root. American Journal of Human Genetics, 90(4), 675-684.

Behjati, S., \& Tarpey, P. S. (2013). What is next generation sequencing? Archives of Disease in Childhood. Education and Practice Edition, 98(6), 236-238.

BioCat. (s.f.). Real Time PCR Dyes. Recuperado 6 de mayo de 2016, de https://www.biocat.com/genomics/real-time-pcr-dyes

Børsting, C., \& Morling, N. (2015). Next generation sequencing and its applications in forensic genetics. Forensic Science International: Genetics, (18), 78-89.

Bourdon, V., Harris, J., Prinz, M., \& Shapiro, E. (2014). Optimization of Human mtDNA Control Region Sequencing for Forensic Applications. Journal of Forensic Sciences, 59(4), $1057-$ 1063.

Brookes, A. J. (1999). The essence of SNPs. Gene, 234, 177-186.

Brüel, A., Christensen, E. I., Tranum-Jensen, J., Qvortrup, K., \& Geneser, F. (2012). Histología (4 $4^{a}$ Edición). Madrid: Editorial Médica Panamericana.

Bruijns, B., Tiggelaar, R., \& Gardeniers, H. (2018). Massively parallel sequencing techniques for 
forensics: A review. Electrophoresis, 39(21), 2642-2654.

Buckleton, J., Triggs, C. M., \& Walsh, S. J. (Eds.). (2005). Forensic DNA Evidence Interpretation. Boca Raton: CRS Press.

Burns, K. R. (2007). Antropología Forense. Barcelona: Bellaterra.

Butler, J. M. (2005). Forensic DNA typing (Second). Burlington: Elsevier.

Butler, J. M. (2010). Fundamentals of Forensic DNA Typing. San Diego: Academic Press.

Butler, J. M. (2011). Advanced Topics in Forensic DNA Typing: Methodology. San Diego: Academic Press.

Butler, J. M. (2014). Advanced Topics in Forensic DNA Typing: Interpretation. San Diego: Academic Press.

Butler, J. M., Coble, M. D., \& Vallone, P. M. (2007). STRs vs. SNPs: thoughts on the future of forensic DNA testing. Forensic Science, Medicine and Pathology, 3, 200-205.

Carracedo, Á., \& Prieto, L. (2014). Valoración de la prueba genética. En ADN Forense: problemas éticos y jurídicos (pp. 145-156). Barcelona: Observatorio de Bioética y Derecho de la Universidad de Barcelona.

Chalmers, A. F. (2010). ¿Qué es esa cosa llamada ciencia? Madrid: Siglo XXI.

Conan Doyle, A. (1887). Estudio en escarlata. (J. A. Molina Foix, Ed.) (3 ${ }^{\text {a }}$ Edición). Madrid: Valdemar.

Corato, S., Giuliodori, A., Ponzano, E., Novelli, E., Rodriguez, D., \& Caenazzo, L. (2011). Two 16S rRNA mitochondrial markers for species identification in forensic science. Forensic Science International: Genetics Supplement Series, 3, e383-e384.

Crecchio, C., \& Stotzky, G. (1998). Binding of DNA on Humic Acids: Effect on Transformation of Bacillus Subtilis and Resistance to DNase. Soil Biol. Biochem., 30(8/9), 1061-1067.

de Knijff, P. (2019). From next generation sequencing to now generation sequencing in forensics. Forensic Science International: Genetics, 38, 175-180.

Dugan, K. A., Lawrence, H. S., Hares, D. R., Fisher, C. L., \& Budowle, B. (2002). An Improved Method for Post-PCR Purification for mtDNA Sequence Analysis. Journal of Forensic Sciences, 47(4), 1-8.

Dutra Corrêa, H. S., Miranda Pedro, F. L., Ricci Volpato, L. E., Machado Pereira, T., Siebert Filho, G., \& Henrique Borges, Á. (2017). Foresic DNA typing from teeth using 
demineralized root tips. Forensic Science International, 280, 164-168.

EdgeBio. (2016). Performa ${ }^{\circledR}$ DTR Gel Filtration Cartridges. Recuperado 4 de mayo de 2019, de https://www.edgebio.com/sites/default/files/32-054v2 PS, Performa DTR Gel Filtration Cartridges 42453_98780.pdf

Federal Bureau Investigation. (s. f.). Frequently Asked Questions on CODIS and NDIS. Recuperado 25 de abril de 2019, de https://www.fbi.gov/services/laboratory/biometricanalysis/codis/codis-and-ndis-fact-sheet

Federal Bureau Investigation. (2011). Quality assurance standards for DNA databasing laboratories. Recuperado de https://www.fbi.gov/file-repository/quality-assurancestandards-for-dna-databasing-laboratories.pdf/view

Fernández Villazala, T., \& García Borrego, J. A. (2016). Derecho procesal penal para la Policía judicial $\left(2^{\mathrm{a}}\right)$. Madrid: Dykinson.

Fregel, R., Almeida, M., Betancor, E., Suárez, N. M., \& Pestano, J. (2011). Reliable nuclear and mitochondrial DNA quantification for low copy number and degraded forensic samples. Forensic Science International: Genetics Supplement, Series 3, e303-e304.

Gabriel, M. N., Huffine, E. F., Ryan, J. H., Los, C. W. N. C. S. Y., Holland, M. M., \& Parsons, T. J. (1999). Improved Strategies For mtDNA Sequence Analysis of Highly Degraded Forensic Remains. En 10th International Symposium on Human Identification (pp. 1-11). Orlando.

Gallimore, J. M., McElhoe, J. A., \& Holland, M. M. (2018). Assessing heteroplasmic variant drift in the mtDNA control region of human hairs using an MPS approach. Forensic Science International: Genetics, 32, 7-17.

Gill, P. (2001). An assessment of the utility of single nucleotide polymorphism (SNPs) for forensic purposes. International Journal of Legal Medicine, 114, 204-210.

Gill, P., Jeffreys, A. J., \& Werret, D. J. (1985). Forensic application of DNA «fingerprints». Nature, 318(12), 577-579.

Ginther, C., Issel-Tarver, L., \& King, M. C. (1992). Identifying individuals by sequencing mitochondrial DNA from theeth. Nature Genetics, 2, 135-138.

Graham, E. A. M. (2007). DNA reviews: Ancient DNA. Forensic Science, Medicine, and Pathology, 3(3), 221-225.

Gurson, N. (2016). How to Set up Sanger Sequencing Run - Seq It Out \#16. Recuperado 26 de abril de 2019, de https://www.thermofisher.com/blog/behindthebench/how-to-set-up-a- 
sanger-sequencing-run-seq-it-out-

16/?cid=social_ABSeq_20160422_60750886\&adbid=723576614123008001\&adbpl=tw\& adbpr $=62862144$

Hagelberg, E., Gray, I. C., \& Jeffreys, A. J. (1991). Identification of the skeletal remains of a murder victim by DNA analysis. Nature, 352(427-429).

Hall, A., \& Ballantyne, J. (2004). Characterization of UVC-induced DNA damage in bloodstains: forensic implications. Annals of Bioannalytical Chemistry, 380(1), 72-83.

Hofreiter, M., Serre, D., Poinar, H. N., Kuch, M., \& Pääbo, S. (2001). Ancient DNA. Nature Reviews Genetics, 2, 353-359.

Holland, M. M., Fisher, D. L., Mitchell, L. G., Rodríguez, W. C., Canik, J. J., Merril, C. R., \& Weedn, V. W. (1993). Mitochondrial DNA Sequence Analysis of Human Skeletal Remains: Identification of Remains from the Vietnam War. Journal of Forensic Sciences, JFSCA, $38(3), 542-553$.

Holland, P. M., Abramson, R. D., Watson, R., \& Gelfand, D. H. (1991). Detection of specific polymerase chain reaction product by utilizing the 5 ' $\rightarrow 3$ ' exonuclease activity of Thermus aquaticus DNA polymerase. Proceedings of the National Academy of Sciences of the United States of America, 88, 7276-7280.

Hubbard, T., Barker, D., Birney, E., Cameron, G., Chen, Y., Clark, L., ... Clamp., M. (2002). The Ensembl genome database project. Nucleic Acids Research, 30(1), 38-41.

Hudlow, W. R., Chong, M. D., Swango, K. L., Timken, M. D., \& Buoncristiani, M. R. (2008). A quadruplex real-time qPCR assay for the simultaneous assessment of total human DNA, human male DNA, DNA degradation and the presence of PCR inhibitors in forensic samples: A diagnostic tool for STR typing. Forensic Science International: Genetics, 2, 108-125.

Ingman, M., \& Gyllensten, U. (2006). mtDB: Human Mitochondrial Genome Database, a resource for population genetics and medical sciences. Nucleic Acids Research, 34, D749D751.

Kaestle, F. A., \& Horsburgh, K. A. (2002). Ancient DNA in anthropology: methods, applications, and ethics. American Journal of Physical Anthropology, 35, 92-130.

Karlen, Y., McNair, A., Perseguers, S., Mazza, C., \& Mermod, N. (2007). Statistical significance of quantitative PCR. BMC Bioinformatics, 8(131), E1-E16.

Kavlick, M. F. (2019). Development of a triplex mtDNA qPCR assay to assess quantification, 
degradation, inhibition, and amplification target copy numers. Mitochondrion, 46, 41-50.

Kent, W., Sugnet, C., Furey, T., Roskin, K., Pringle, T., Zahler, A., \& Haussler, D. (2002). The guman genome browser at UCSC. Genome Res., 12(6), 996-1006.

Kocher, T. D., Thomas, W. K., Meyer, A., Edwards, S. V., Pääbo, S., Villablanca, F. X., \& Wilson, A. C. (1989). Dynamics of mitochondrial DNA evolution in animals: Amplification and sequencing with conserved primers. Proceedings of the National Academy of Sciences of the United States of America, 86(6196-6200).

Kogelnik, A. M., Lott, M. T., Brown, M. D., Navathe, S. B., \& Wallace, D. C. (1996). MITOMAP: a human mitochondrial genome database. Nucleic Acids Research, 24(1), 177179.

Krause, J., \& Pääbo, S. (2016). Genetic Time Travel. Genetics, 203(1), 9-12.

Lindahl, T. (1993). Instability and decay of the primary structure of DNA. Nature, 362, 709-715.

Llamas, B., Valverde, G., Fehren-Schmitz, L., Weyrich, L. S., Cooper, A., \& Haak, W. (2017). From the field to the laboratory: Controlling DNA contamination in human ancient DNA research in the high-throughput sequencing era. STAR: Science \& Technology of Archeological Research, 3(1), 1-14.

Loreille, O. M., \& Irwin, J. A. (2015). Capillary Electrophoresis of Human mtDNA Control Region Sequences from Highly Degraded Samples Using Short mtDNA Amplicons. En A. Alonso (Ed.), DNA Electrophoresis Protocols for Forensic Genetics (pp. 283-299). Hertfordshire: Humana Press.

Lorente, J. A. (2004). Un detective llamado ADN. Madrid: Temas de Hoy.

Luoa, S., Valencia, C. A., Zhangc, J., Leed, N.-C., Slonea, J., Guia, B., ... Huang, T. (2018). Biparental Inheritance of Mitochondrial DNA in humans. Proceedings of the National Academy of Sciences, 115(51), 13039-13044.

Lutz, S., Wittig, H., Weisser, H.-J., Heizmann, J., Junge, A., Dimo-Simonin, N., ... Augustin, C. (2000). Is it possible to differentiate mtDNA by means of HVIII in samples that cannot be distinguished by sequencing the HVI and HVII regions? Forensic Science International, 113, 97-101.

Miloš, A., Selmanović, A., Smajlović, L., Huel, R. L. M., Cheryl Katzmarzyk, A. R., \& Parsons, T. J. (2007). Success Rates of Nuclear Short Tandem Repeat Typing from Different Skeletal Elements. Croatian Medical Journal, 48(4), 486-493.

Miyazaki, H. (2015). Bloodborne. Tokyo: From Software. 
Montesino, M., \& Prieto, L. (2012). Capillary Electrophoresis of Big-Dye Terminator Sequencing Reactions for Human mtDNA Control Region Haplotyping in the Identification of Human Remains. En A. Alonso (Ed.), DNA Electrophoresis Protocols for Forensic Genetics (pp. 267-281). Hertfordshire: Humana Press.

Montiel Duarte, R. (2003). Capítulo 8. Aplicación de las técnicas de ADN antiguo en paleopatología. Problemas y perspectivas. En Paleopatología. La enfermedad no escrita (pp. 75-89). Barcelona: Masson.

Nass, M. M. K., \& Nass, S. (1963). Intramitochondrial fibers with DNA characteristics. The Journal of Cell Biology, 19, 593-611.

National Center for Biotechnology Information. (s. f.). Genome information by Organism. Recuperado de https://www.ncbi.nlm.nih.gov/genome/browse\#!/organelles/

Niederstätter, H., Köchl, S., Grubweiser, P., Pavlic, M., Steinlechner, M., \& Parson, W. (2007). A modular real-time PCR concept for determining the quantity and quality of human nuclear and mitochondrial DNA. Forensic Science International: Genetics, 1, 29-34.

Pääbo, S., Poinar, H., Serre, D., Jaenicke-Després, V., Hebler, J., Rohland, N., ... Hofreiter, M. (2004). Genetic Analyses from Ancient DNA. Annual Review of Genetics, 38, 645-679.

Parson, W., Gusmão, L., Hares, D. R., Irwin, J. A., Mayr, W. R., Morling, N., ... Parsons, T. J. (2014). DNA Commission of the International Society for Forensic Genetics: Revised and extended guidelines for mitochondrial DNA typing. Forensic Science International: Genetics, 13, 134-142.

Parson, Walther, \& Dür, A. (2007). EMPOP - A forensic mtDNA database. Forensic Science International: Genetics, 1, 88-92.

Pevsner, J. (2009). Bioinformatics and Functional Genomics (2 $2^{\text {a }}$ Edición). New Jersey: WileyBlackwel.

Phillips, N. R., Sprouse, M. L., \& Roby, R. K. (2014). Simultaneous quantification of mitochondrial DNA copy number and deletion ratio: A multiplex real-time PCR assay. Scientific Reports, 4(3887), 1-7.

Pierce, B. A. (2006). Genética. Un enfoque conceptual (2 ${ }^{\mathrm{a}}$ Edición). Madrid: Editorial Médica Panamericana.

Pilli, E., Vai, S., Caruso, M. G., D’Errico, G., Berti, A., \& Caramelli, D. (2018). Neither femur nor tooth: Petrous bone for identifying archeological bone samples via forensic approach. Forensic Science International, 283, 144-149. 
Poinar, H. N. (2003). The top 10 list: criteria of authenticity for DNA from ancient and forensic samples. International Congress Series 1239, 1239, 575-579.

QIAGEN. (2018). QIAquick® PCR Purification Kit QIAquick® PCR \& Gel Cleanup Kit. $\begin{array}{llllll}\text { Recuperado } & 4 & \text { de } & \text { de }\end{array}$ https://www.qiagen.com/us/resources/resourcedetail?id=e0fab087-ea52-4c16-b79fc224bf760c39\&lang=en

Refinetti, P., Warren, D., Morgenthaler, S., \& Ekstrøm, P. O. (2017). Quantifying mitochondrial DNA copy number using robust regression to interpret real time PCR results. BMC Res Notes, 10(593), E1-E7.

Roby, R. K., Sprouse, M., Phillips, N., Alicea-Centeno, A., Shewale, S., Shore, S., \& Paul, N. (2014). Mitochondrial Genome Interrogation for Forensic Casework and Research Studies. Current Protocols in Human Genetics, 14.9.1-14.9.23.

Rohland, N., \& Hofreiter, M. (2018). Comparison and optimization of ancient DNA extraction. BioTechniques, 42(3), 343-352.

Romanowski, G., Lorenz, M. G., \& Wackernagel, W. (1991). Adsorption of Plasmid DNA to Mineral Surfaces and Protection against DNase I. Applied and Environmental Microbiology, Apr., 1057-1061.

Sanger, F., Nicklen, S., \& Coulson, R. (1977). DNA sequencing with chain-terminating inhibitors. Proceedings of the National Academy of Sciences, 74(12), 5463-5467.

Scientific Working Group on DNA Analysis Methods. (2019a). Addendum to «SWGDAM Interpretation Guidelines for Autosomal STR Typing by Forensic DNA Testing Laboratories» to Address Next Generation Sequencing. Recuperado de https://docs.wixstatic.com/ugd/4344b0_91f2b89538844575a9f51867def7be85.pdf

Scientific Working Group on DNA Analysis Methods. (2019b). SWGDAM Interpretation Guidelines for Mitochondrial DNA Analysis by Forensic DNA Testing Laboratories. Recuperado de https://docs.wixstatic.com/ugd/4344b0_f61de6abf3b94c52b28139bff600ae98.pdf

Shapiro, B., \& Hofreiter, M. (Eds.). (2012). Ancient DNA. Methods and Protocols. York: Humana Press.

Sung Tz'u. (1981). The Washing away of Wrongs: Forensic Medicine in Thirteenth-Century China. (B. E. McKnight, Ed.). Stellenbosch: Centre for Chinese Studies Publications.

Swango, K. L., Timken, M. D., Chong, M. D., \& Buoncristiani, M. R. (2006). A quantitative PCR 
assay for the assessment of DNA degradation in forensic samples. Forensic Science International, 158, 14-26.

Tabak, J. (2019). First Criminal Conviction Secured with Next-Gen Forensic DNA Technology. Recuperado 6 de junio de 2019, de https://verogen.com/news/first-criminal-convictionwith-next-gen-forensic-dna/

Thompson, W. C., \& Schumann, E. L. (1987). Interpretation of Statistical Evidence in Criminal Trials. The Prosecutor's Fallacy and the Defense Attorney's Fallacy. Law and Human Behavior, 11(3), 167-187.

Thorwald, J. (1966). El siglo de la investigación criminal. Barcelona: Editorial Labor.

Timken, M. D., Swango, K. L., Orrego, C., \& Buoncristiani, M. R. (2005). A Duplex Real-Time qPCR Assay for the Quantification of Human Nuclear and Mitochondrial DNA in Forensic Samples: Implications for Quantifying DNA in Degraded Samples. Journal of Forensic Sciences, 50(5), 1-17.

Valasek, M. A., \& Repa, J. Y. (2005). The power of real-time PCR. Advances in Physiology Education, 29, 151-159.

van Oven, M. (2009). Updated comprehensive phylogenetic tree of global human mitochondrial DNA variatioon. Human Mutation, 30(2), E386-E394.

Verogen. (2019). ForenSeq mtDNA. Recuperado 13 de mayo de 2019, de https://verogen.com/forenseq-mtdna-analysis-coming-soon/

Weissensteiner, H., Packer, D., Kloss-Brandstätter, A., Forer, L., Specht, G., Bandelt, H.-J., ... Schönherr, S. (2016). HaploGrep2: mitochondrial haplogroup classification in the era of high-throughput sequencing. Nucleic Acids Research, 15.

Wilson, M. R., DiZinno, J. A., Polanskey, D., Replogue, J., \& Budowle, B. (1995). Validation of mitochondrial DNA sequencing for forensic casework analysis. International Journal of Legal Medicine, 108, 68-74.

Yang, L., Tan, Z., Wang, D., Xue, L., Guan, M., Huang, T., \& Li, R. (2014). Species identification through mitochondrial rRNA genetic analysis. Scientific Reports, 4(4089).

Yang, Y., Xie, B., \& Yan, J. (2014). Application of Next-generation Sequencing Technology in Forensic Science. Genomics Proteomics Bioinformatics, 12, 190-197.

Young, J. M., Rawlence, N. J., Weyrich, L. S., \& Cooper, A. (2014). Limitations and recommendations for successful DNA extraction from forensic soil samples: A review. Science and Justice, 54, 238-244. 
Zipper, H., Buta, C., Lämmle, K., Brunner, H., Bernhagen, J., \& Vitzthum, F. (2003). Mechanisms underlying the impact of humic acids on DNA quantification by SYBR Green I and consequences for the analysis of soils and aquatic sediments. Nucleic Acids Research, 31(7), e39. 


\section{Glosario}

A. Adenina.

ADN. Ácido desoxirribonucleico.

ADNmt. ADN mitocondrial.

BSA. Bovine Serum Albumin. Albúmina de Suero Bovino.

C. Citosina

ddNTP. Dideoxinucleótido.

dNTP. Desoxinucleótido.

DTT. Ditiotreitol o Reactivo de Cleland.

EB. Buffer de Tris-Cl $10 \mathrm{mM}$.

EM. Emisión.

EX. Excitación.

g. Fuerza g (medida de aceleración). $1 \mathrm{G}=9,8 \mathrm{~m} / \mathrm{s}^{2}$ (gravedad terrestre a nivel del mar).

g. Gramo.

G. Guanina.

HV. Hipervariable.

HV1. Región Hipervariable 1.

HV2. Región Hipervariable 2.

HV3. Región Hipervariable 3.

Hz. Hercio. $1 \mathrm{~Hz}=\mathrm{s}^{-1}$.

IUPAC. International Union of Pure and Applied Chemistry. Unión Internacional de Química Pura y Aplicada

kb. Kilobases. 1000 pares de bases.

kDa. KiloDalton. Unidad de masa atómica definida como la doceava parte de un átomo neutro, no enlazado, de Carbono-12. 
M. Molar. 1 mol por litro.

Mb. Megabases. $10^{6}$ pares de bases.

mM. Milimolar. $10^{-3} \mathrm{~mol}$ por litro.

MPS. Mini Primer Set.

ng. Nanogramo. $10^{-9}$ gramos.

${ }^{\circ} \mathbf{C}$. Grados centígrados.

pb. Pares de bases.

PCR. Polimerase Chain Reaction. Reacción en cadena de la polimerasa.

PE. Buffer de etanol y Tris.

pM. Picomolar. $10^{-12} \mathrm{~mol}$ por litro.

POP. Matriz de separación de tipo polímero para electroforesis capilar.

PS. Primer Set.

qPCR. PCR cuantitativa.

rCRS. Revised Cambridge Reference Sequence. Secuencia de Referencia de Cambridge Revisada.

rt-PCR. PCR a tiempo real.

s. Segundos.

SAM. Buffer de BigDye XTerminator.

SDS. Diocesilsulfato sódico.

SNP. Single nucleotide polymorphism. Polimorfismo de un solo nucleótido.

STR. Short Tándem Repeats. Repeticiones cortas en tándem.

T. Timina.

TBE. Buffer de Tris (54 g), ácido bórico (27,5 g) y EDTA (20 ml 0,5 M).

TE. Buffer de Tris $(10 \mathrm{mM})$ y EDTA (1mM).

Tris. Tris(hidroximetil)aminometano.

UCSC. Universidad de California en Santa Cruz. 
VNTR. Variable Number of Tandem Repeats. Repeticiones en tándem de número variable.

$\mu \mathrm{g}$. Microgramos. $10^{-6}$ gramos.

$\boldsymbol{\mu l}$. Microlitros, $10^{-6}$ litros.

$\boldsymbol{\mu M}$. Micromolar. $10^{-6} \mathrm{~mol}$ por litro. 
